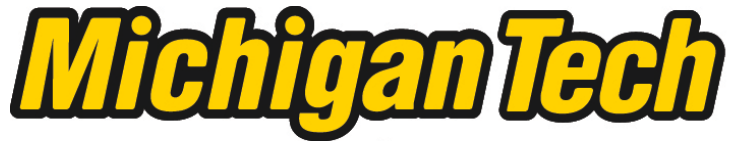 \\ Michigan Technological University Create the Future Digital Commons @ Michigan Tech
}

Dissertations, Master's Theses and Master's Reports - Open

Dissertations, Master's Theses and Master's

Reports

2011

\section{"Brethren upon the same level" : membership and class in Calumet's Masonic Lodge}

Brandon Anthony Sexton

Follow this and additional works at: https://digitalcommons.mtu.edu/etds

Part of the Archaeological Anthropology Commons

Copyright 2011 Brandon Anthony Sexton

\section{Recommended Citation}

Sexton, Brandon Anthony, "'Brethren upon the same level" : membership and class in Calumet's Masonic Lodge", Master's Thesis, Michigan Technological University, 2011.

https://doi.org/10.37099/mtu.dc.etds/288

Follow this and additional works at: https://digitalcommons.mtu.edu/etds

Part of the Archaeological Anthropology Commons 
"BRETHREN UPON THE SAME LEVEL":

MEMBERSHIP AND CLASS IN CALUMET'S MASONIC LODGE

By

Brandon Anthony Sexton

\begin{abstract}
A THESIS
Submitted in partial fulfillment of the requirements for the degree of MASTER OF SCIENCE

(Industrial Archaeology)
\end{abstract}

MICHIGAN TECHNOLOGICAL UNIVERSITY

2011

C 2011 Brandon Anthony Sexton 
This thesis, ““'Brethren Upon The Same Level”: Membership and Class in Calumet's Masonic Lodge," is hereby approved in partial fulfillment of the requirements for the Degree of MASTER OF SCIENCE IN INDUSTRIAL ARCHAEOLOGY.

Department of Social Sciences

Signatures:

Thesis Advisor

Dr. Larry Lankton

Department Chair

Dr. Patrick Martin

Date 
To my parents 


\section{Table of Contents}

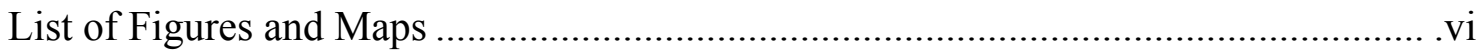

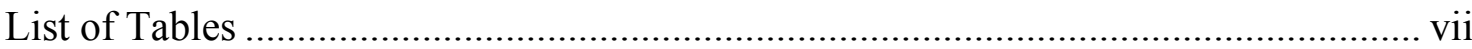

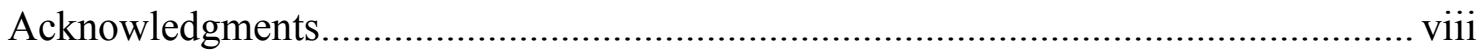

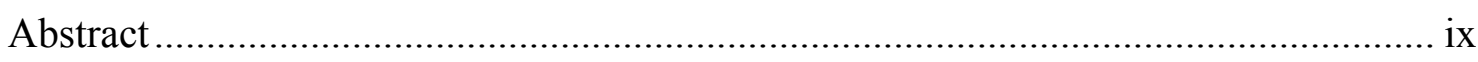

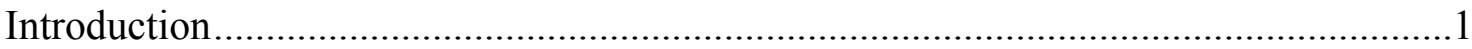

The Keweenaw: A Social Conglomerate ............................................................1

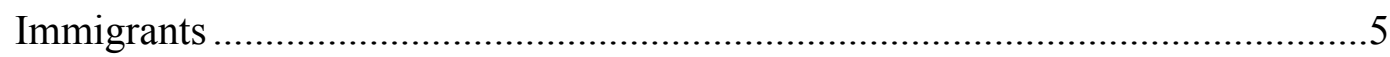

Research Questions and Methodologies ........................................................6

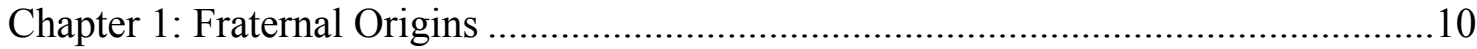

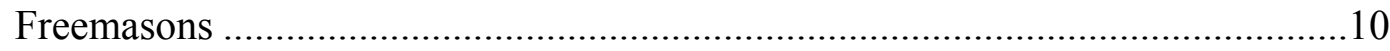

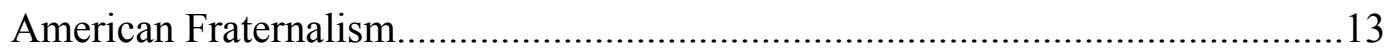

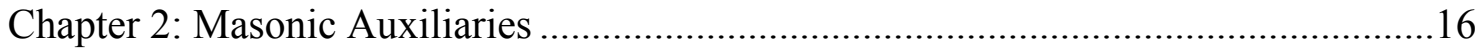

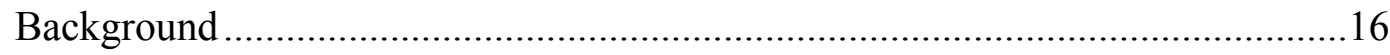

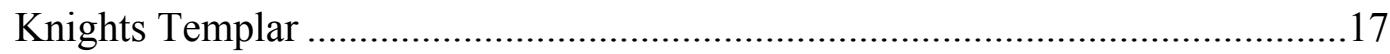

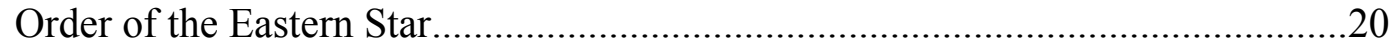

Chapter 3: Membership Motivation and Costs .....................................................25

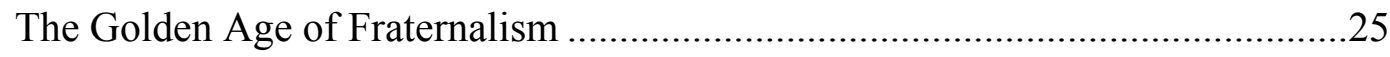

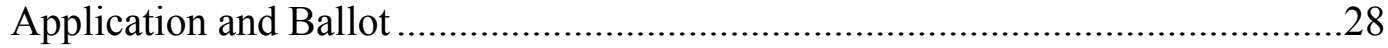

Chapter 4: A Means of Respectability ...............................................................33

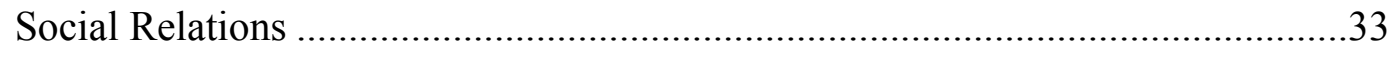

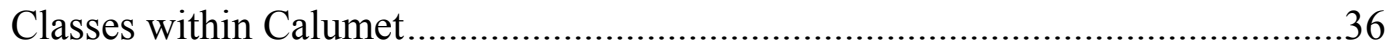

Chapter 5: "Brethren Upon the Same Level": Class Membership ...............................38

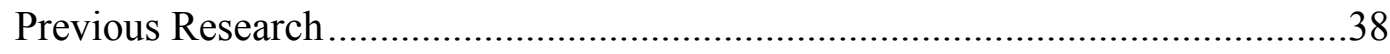

Division Between Occupations..................................................................40

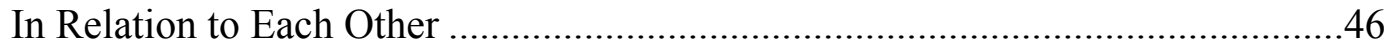

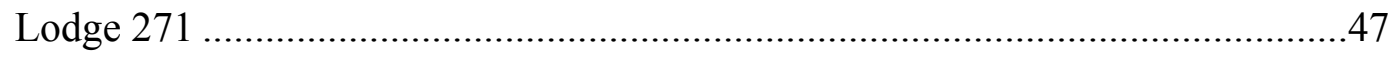

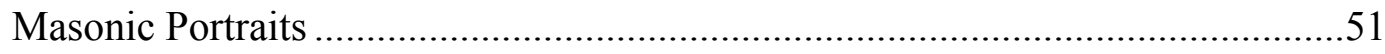

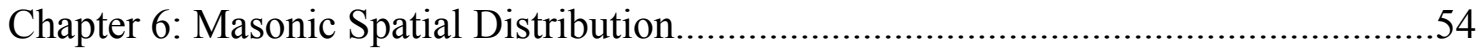




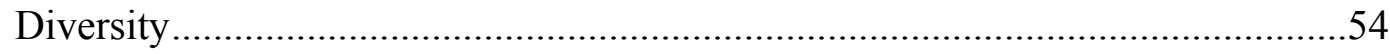

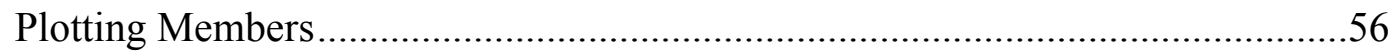

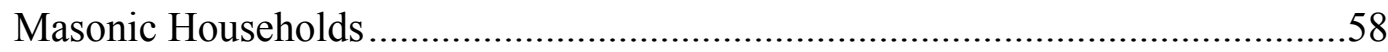

Chapter 7: Masonic Ritual ........................................................................................71

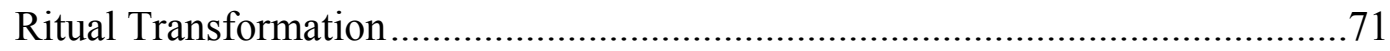

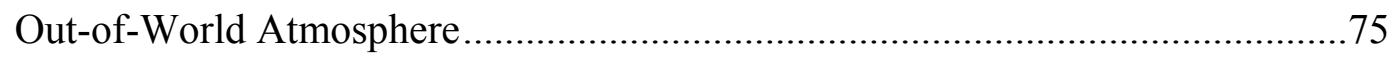

Ritualistic Symbolism: The Blue Lodge ...........................................................79

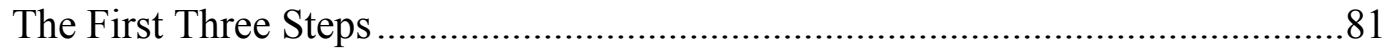

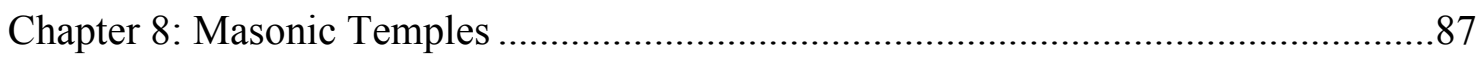

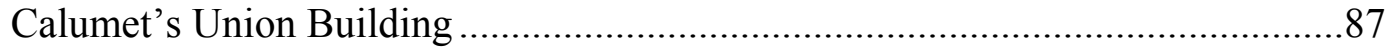

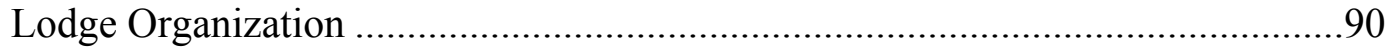

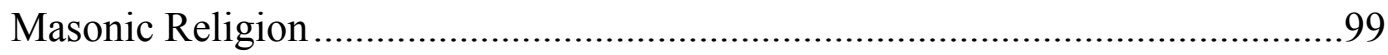

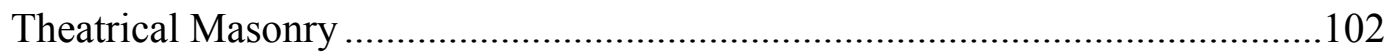

Chapter 9: Masonic Items …………………………................................................107

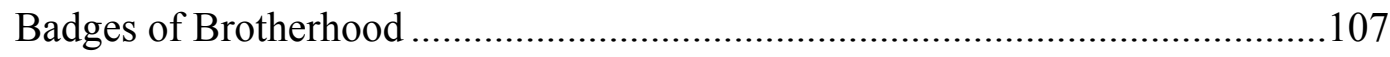

Threshold Values ........................................................................................ 110

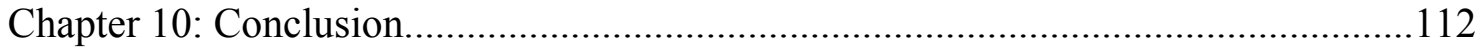

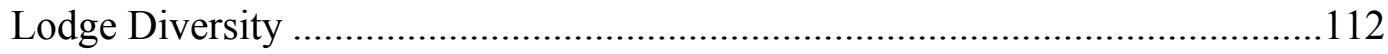

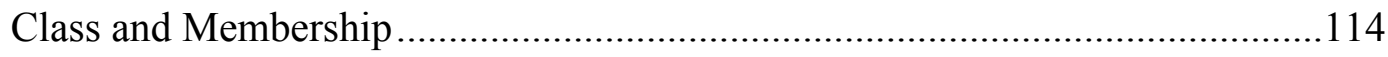

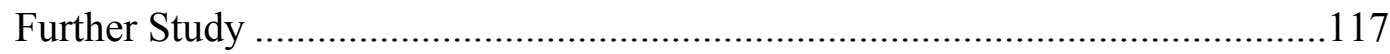

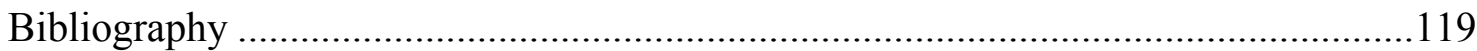

Appendix: List of Members ................................................................................125

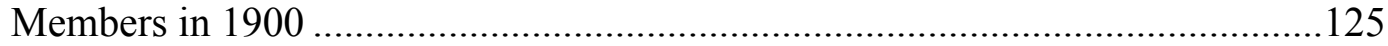

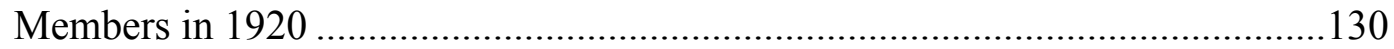




\section{List of Figures and Maps}

Figure 3.1: Sears Roebuck and Company Masonic Charms......................................26

Figure 3.2: 1870 Application to Join Masonic Lodge 271 .......................................29

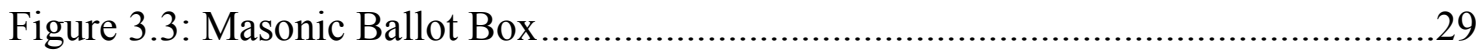

Figure 6.1: Comparison of Membership Between 1900 and 1920 ...........................60

Figure 6.2: Comparison of Membership - Mohawk-Houghton ...................................61

Figure 6.3: Masonic Membership Divided by Class in 1900 ...................................62

Figure 6.4: Masonic Membership Divided by Class in 1920 ...................................63

Figure 6.5: High-Low Clustering Report for 1900 ...............................................64

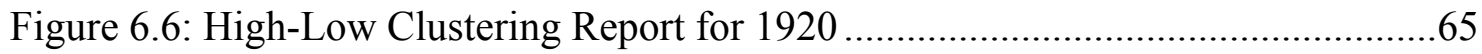

Figure 6.7: Average Nearest Neighbor for 1900 ..................................................66

Figure 6.8: Average Nearest Neighbor for 1920 .................................................67

Figure 6.9: 118 Amygdaloid - James Wilson.....................................................68

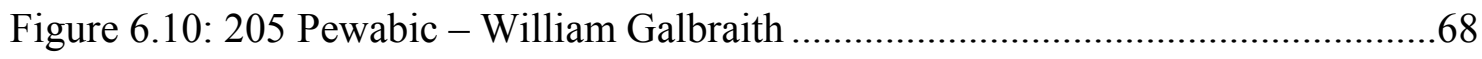

Figure 6.11: 322 8th Street - Thomas Gribble ..................................................69

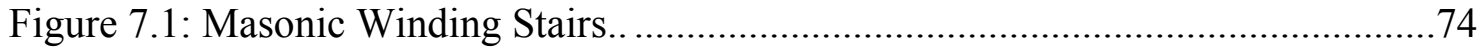

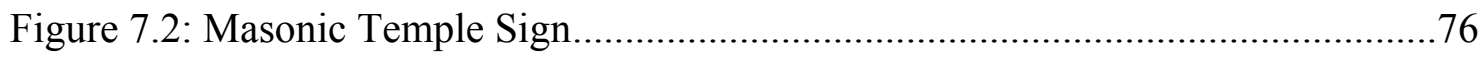

Figure 8.1: Layout of the Union Building's Third Floor ........................................92

Figure 8.2: Masonic Ritual Movement ...............................................................93

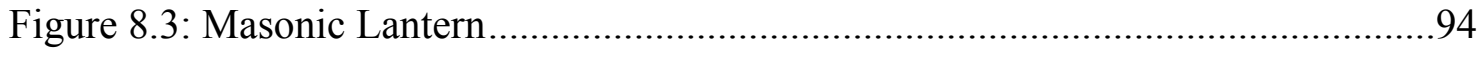

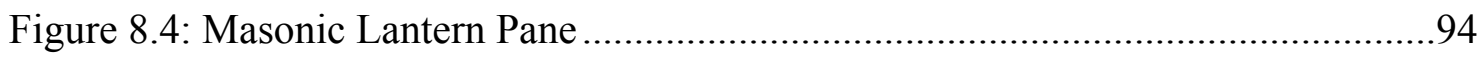

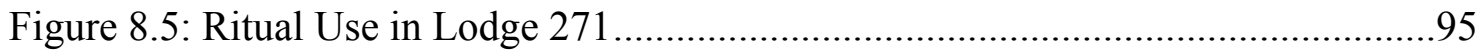

Figure 8.6: The Masonic Temple Today ............................................................ 97

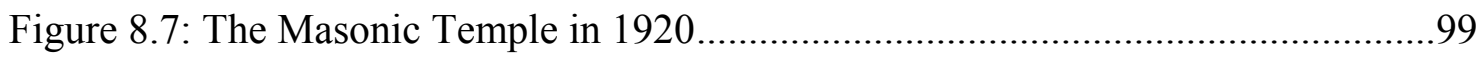

Figure 8.8: Exterior of the Union Building Today ............................................. 101

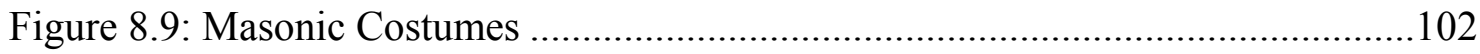

Figure 8.10: The Michigan Lantern for Masonic Rituals ......................................103

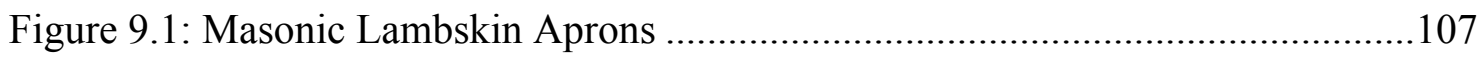

Figure 9.2: More Variations in the Aprons .......................................................... 108 


\section{List of Tables}

Table 5.1: Social Classes by Occupation................................................................43

Table 5.2: Membership in 1900 and 1920 Divided by Class....................................48

Table 5.3: Occupation Distribution in the United States in 1900 and 1920 .................50

Table 10.1: Ethnic Groups within Red Jacket, c. 1900...........................................112

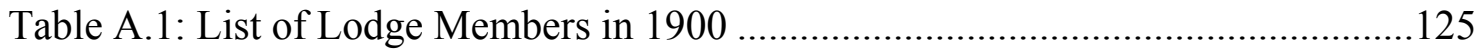

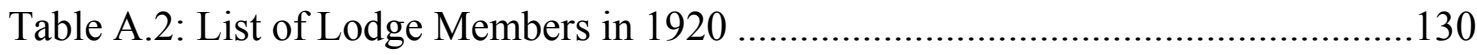




\section{Acknowledgments}

This thesis is the result of not only my own actions but also other individuals and organizations. First I would like to thank Dr. Larry Lankton, my advisor, for reading, guiding, and editing, and my committee members Dr. Susan Martin, Dr. Timothy Scarlett, and Jo Urion, Historian with the National Park Service at the Keweenaw National Historical Park, who offered new insight and approaches. Also I would like to thank Dr. Ann Maclean with Michigan Tech for her help with the GIS data spatial analysis.

I am thankful to the Social Sciences Department, who supported me while I conducted my research. Also aiding in my research was the Keweenaw National Historical Park's help in accessing the Union Building and their collections. I am also grateful to the members of Calumet's Masonic Lodge 271 who kept the detailed records that allowed me to examine the role of economic membership within the lodge setting, and the Michigan Technological University Archives and Copper Country Historical Collection for their help and service. 


\begin{abstract}
The Keweenaw Peninsula of Upper Michigan was a ethnic conglomerate of cultures and ideas, with people attracted to the area by the mineral wealth found along the Copper Range. The center of copper mining from the mid 1860s to 1968 was in the vicinity of Calumet Township, home to the world-famous Calumet and Hecla Mining Company. The township depended on the mines and the company's president Agassiz's strove to make the area a "model community," that included groups such as the Free and Accepted Masons. Men from myriad backgrounds arrived in Calumet from the British Isles, Germany, Finland, Eastern and Southern Europe and the Eastern United States. As in other communities from the time period these men formed common interest groups like Masonic Lodge 271, which received its charter in 1870. Gentlemen joined with merchants and craftsmen. They became "brethren upon the same level," and were elevated to the status of Master Mason. This symbolic transformation within the Lodge removed the men from the "profane world" outside the sanctity of Masonry, and in the ritualistic transformation of the meeting they were reborn into Masonry's sacred mysteries.

Masonry acted as a means of moral guidance to men and gave them access to a larger social and economic community through a common connection of brotherhood. As the candidates moved through the three Blue Lodge degrees of Entered Apprentice, Fellowcraft, and Master Mason they saw each other as "brethren upon the same level" all economic classes equal within the Masonic Lodge. ${ }^{1}$ To examine equality within Lodge 271, this study sorted workers into classes to allow a comparison of Lodge 271 's membership. Possibly a comparison between other lodges can be drawn from the membership. The Union Building in Calumet, MI will be examined for its role in the ritualistic transformation of Masonry as it housed Masonic activities and transformations. This transformation brought men into the lodge of brothers. While Masonry professed equality between members however, to what extent did the membership of the lodge reflect this between the brethren? To what extent did economic class determine who was made "brethren upon the same level?
\end{abstract}

\footnotetext{
${ }^{1}$ Arthur Thurner, Calumet Copper and People: History of a Michigan Mining Community, 1864-1970 (Hancock, MI: Book Concern, 1974), 122.
} 


\section{Introduction}

\section{The Keweenaw: A Social Conglomerate}

The Keweenaw Peninsula is situated on Lake Superior, and extends about seventy miles into the lake from Michigan's Upper Peninsula. Ancient lava flows from 1.2 billion years ago captured largely pure copper deposits that brought people to the area to mine the red metal. Beginning in the 1840 s the Copper Country's population grew from a small group of hunters, trappers, and Native Americans to nearly 100,000 newcomers by $1910 .{ }^{1}$ Initially the Keweenaw drew its labor chiefly from "the British Isles, Western Europe and Canada." ${ }^{2}$ After 1890, immigrants largely arrived from Finland, and Southern and Eastern Europe. Men arrived to extract the red metal from the earth and in doing so the numerous nationalities formed an "ethnic conglomerate" and with many groups "retain[ing] many [of their] national characteristics.",3

The village of Red Jacket was organized in the late 1860s and grew out of a "remote, densely forested wilderness into a commercial and cultural center." ${ }^{\text {"To avoid }}$ confusion over the name Calumet, within this study the place names of Red Jacket and Calumet will be used interchangeably while the current village Laurium is referred to as Laurium. Early prospectors such as Edwin Hulbert, first president of the separate

\footnotetext{
${ }^{\mathbf{1}}$ Larry Lankton, Cradle to Grave : Life, Work, and Death at the Lake Superior Copper Mines (New York: Oxford UP, 1993), 22.

2 “An Interior Ellis Island,” Michigan Tech Archives and Copper Country Historical Collections, http://ethnicity.lib.mtu.edu/intro.html.

3 Thurner, Calumet Copper and People, 13.

${ }^{4}$ Alison K. Hoagland, Mine Towns: Buildings for workers in Michigan's Copper Country (Minneapolis: University of Minnesota Press, 2010), xvi. See also Larry Lankton, Hollowed Ground: Copper Mining and Community Building on Lake Superior, 1840s-1990s (Detroit: Wayne State University Press, 2010), 71 .
} 
Calumet and Hecla mining companies, found a land "isolated from the rest of the world nearly six months of the year," when the frozen lakes halted transportation. ${ }^{5}$ In May 1871 the Calumet and Hecla Mining Companies consolidated into Calumet and Hecla, which sat above the richest copper lode on the Keweenaw - the Calumet conglomerate. In 1871 the Boston Sunday Globe declared that Calumet and Hecla "the richest mine ever opened." 6 This announcement brought in more financial and human capital to operate the mines. The company "could hardly fail to profit, because the lode [it straddled] was so rich.” Between 1870 and 1900 Calumet and Hecla produced between fifty-four and sixty-five percent of Michigan's copper output, with a peak of $65.3 \%$ in 1872. ${ }^{7}$ Calumet and Hecla thus operated "one of the largest copper mines in the world." " The "healthy climate, abundance of work, and good pay" convinced many immigrants that the "Keweenaw, more than any other place in the United States was the place to live."9 The company, along with Calumet Township and the surrounding area including the villages of Red Jacket, and Laurium, resulted from Agassiz's drive to make the area a "model community, with pronounced social controls." "While Agassiz himself wasn't a Mason he saw value in the stability the lodge offered - it is speculated men at a fraternal meeting were less likely to cause problems by drinking or joining organized labor. This was seen in The Free and Accepted Masons, Benevolent and Protective Order of the Elks, and Foresters of America which all established lodges in

\footnotetext{
${ }^{5}$ Keweenaw National Historical Park, Downtown Calumet: Guide to the historic mining community (Washington, DC: NPS, 2006), 3.

${ }^{6}$ Arthur Thurner, Strangers and Sojourners (Detroit: Wayne State UP, 1994), 88.

${ }^{7}$ William Gates, Michigan Copper and Boston Dollars: An Economic History of the Michigan Copper Mining Industry (Cambridge: Harvard UP, 1951), 230.

${ }^{8}$ Alvah Littlefield Sawyer, A History of the Northern Peninsula of Michigan and its People (Chicago: The Lewis Publishing Co., 1911), 96.

${ }^{9}$ Thurner, Strangers and Sojourners, 124.

${ }^{10}$ Ibid, 122.
} 
Calumet. However the other lodges are not included in this study due to limited records regarding their membership. By 1900 the Village of Red Jacket surpassed Houghton and Hancock as the economic center of the Copper Country. This attracted "miners, trammers, and timbermen...doctors, forwarding agents, [and] wholesale dealers" as they built "vital and energetic communities." ${ }^{.11}$ As a result of the red metal the area near Calumet Township rose rapidly, paralleling the fortunes of the copper mines.

Calumet in 1900 presented the core of Michigan's copper mines. Houghton County had the state's fourth largest population - after Wayne, Kent and Saginaw Counties. ${ }^{12}$ In between Calumet and Laurium along County Road (now US-41) sat the industrial core of workshops and mines. Located at the far north of the village was Calumet Shaft No. 18, while near the southern tip of Laurium stood Hecla Shaft No. 8. Along the copper lode ran a string of shafthouses, surface plants, and railroad tracks that moved the ore and machinery. It was through this scene that men walked to work, with twelve shafthouses in and around Calumet. The Frontenac Compressor, and the Superior Boiler Houses, along with the Calumet and Torch Lake Round House added to this industrial landscape. To support the machines nearly forty thousand people lived in the surrounding area. In 1907 5,603 men worked for the mighty Calumet and Hecla. ${ }^{13}$ It was in this setting that men came to work in the mines, bringing their families or leaving them behind in search of work. Many of these early immigrants from the British

\footnotetext{
${ }^{11}$ Thurner, Strangers and Sojourners, 94.

${ }^{12}$ U.S. Census of Population and Housing, 1900: Summary Population and Housing Characteristics: Michigan. Washington: Government Printing Office, 1901

${ }^{13}$ Gates, Michigan Copper and Boston Dollars, 209
} 
Isles brought cultural traditions with them that took root in the Keweenaw, including the Masonic Lodge.

When the Masonic Lodge 271 was founded in 1870, the village of Red Jacket was still in its infancy but enjoyed a rapidly growing population. According to the Masonic ritual adopted by the Grand Lodge of Michigan at the time, a new lodge could be constituted when "any number of Master Masons, not under seven, [desired to form] a new lodge, [and they applied]...to the Grand Lodge of the State in which they reside." ${ }^{14}$ The twenty-two men who organized the Lodge included John Duncan, Rueben Osborn, Stephen Paull and F.G. White. Other members included J.B Allenbacker, L.A. Columbus, J. Day, John Dymock, Jacob Geiger, James Grierson, S.B. Harris, C.G. Iverson, A. Jaehing, James Laranger, W.B. Markin, H.T. Meig, John S. Morrison, Duncan MacDonald, O.B. Robinson, H.B. Rogers, E.M. Shears, and Thomas Wills. ${ }^{15}$ The Calumet and Hecla Mining Company employed Reuben Osborn as the senior physician in their hospital; he acted as the "secretary on the executive committee to the Calumet and Hecla Employees Aid Fund.” John Duncan also had a prominent place in the company, serving as the general manager of surface and field operations from 1868-1882. At the peak he supervised twelve hundred employees and "a monthly output of copper products valued at more than $\$ 620,000 . " 16$ Both Duncan and Osborn, as part of the company's control over the community, served on Calumet's Washington School's Board of Trustees for many years. This group of prominent men from the

\footnotetext{
${ }^{14}$ William H. Drew, The Freemason's Hand-Book: Containing the Ritual of Freemasonry (New York: Macoy and Sickles, 1860), 131.

${ }^{15}$ Copper Country Masons, Acc. \# 0035 Box 42, Folder 1. MTU \& CCHC.

${ }^{16}$ Copper Country Masons, Acc. \# 0035 Box 48. MTU \& CCHC.
} 
community served as a means to attract more potential members. From the initial group of twenty-two Masons lodge membership grew to 159 by 1900 and 219 by 1920 .

\section{Immigrants}

As immigrants came to America from myriad countries fraternal groups became a refuge among friends, and like the church, they touched community life from weekly gatherings to parades and ceremonies. Men pledged themselves as Eagles, Elks, Masons, or Nobles in rituals beset in imagery and lore. Men from all walks of life sought out and joined these orders. They came from multiple social classes, ethnicities, or churches. Membership ledgers from one lodge, the Free and Accepted Masons 271, provide insight into the socioeconomic relationships between members within a vital part of the community life. Within the Lodge a social sphere of Calumet can be understood by examining the male-only organization. By tracing membership over decades, a story of Calumet's social fabric can be formed. The membership ledgers, Polk Directories, and census data can be used to understand who the members were, their economic class, where they lived. These integrated and became a part of the Masonic ritual that formed their identity.

Norwegians, Swedes and Finns joined early immigrants to the Copper Country in the 1870 s, followed by Poles and Italians in the $1880 \mathrm{~s} .{ }^{17}$ As a result of this influx just under fifty percent of Houghton County's population was foreign born in $1880 .{ }^{18}$ This

\footnotetext{
${ }^{17}$ Thurner, Calumet Copper and People, 13.

${ }^{18}$ Gates, Michigan Copper and Boston Dollars, 230.
} 
stayed roughly stable; by 1900 it stood at forty-seven percent. ${ }^{19}$ The number of foreignborn residents in the area transformed the Copper Country into an Interior Ellis Island. ${ }^{20}$ While many immigrants came to the Keweenaw, they later left for other parts of the country after undergoing Americanization. The Keweenaw was an entry point, a transformative experience like Ellis Island. As a result Calumet had an ethnically diverse population that spoke over twenty languages in the public schools in 1906. The area also had multiple foreign-language newspapers, with eight listed in the 1903 Polk's Directory. The papers were developed to "aid the communication among...diverse peoples." ${ }^{21}$ The village was home to "three banks...two hospitals, an electric street railway and every sanitary convenience. ${ }^{, 22}$ Most ethnic groups formed societies that helped fellow countrymen find work, enter into American society, and to provide a meeting place among friends. A majority of the ethnic groups formed beneficial societies like the St. Stanislaus Polish Mutual Aid Society or the Italian Social Club. Immigrants from the British Isles and Northern Europe joined groups such as the Independent Order of Odd Fellows and the Free and Accepted Masons that catered to a more diverse ethnic membership.

\section{Research Questions and Methodologies}

This study is framed between 1900 and 1920, at the height of Masonic membership in Calumet. While the Lodge operated from 1870 to 1974, the bulk of material pertaining to membership spans 1899-1930. Printed manuals and guides from

\footnotetext{
${ }^{19}$ Gates, Michigan Copper and Boston Dollars, 228.

20 "An Interior Ellis Island."

${ }^{21}$ Thurner, Calumet Copper and People, 13.

${ }^{22}$ Sawyer, A History of the Northern Peninsula of Michigan, 97.
} 
the 1870 's and 1880s also illuminate the operation of the lodge. As the men underwent the rite of passage into their new brotherhood they were removed from society at large, donned the stylized ceremonial clothing and underwent instruction in the sacred writ. Masons believed these ceremonies were passed down from a Biblical figure and "through a chosen few" to them in their initiation ceremony. ${ }^{23}$ This culminated in their ceremonial rebirth as a Masonic brother. It was common practice that over the course of the next few lodge meetings the men to undertook the next two degrees, moving from Entered Apprentice to Fellowcraft and finally Master Mason. Through the initiation ritual they left their worldly social standing at the threshold. Did the lodge ritual that "intensified the bonds of friendship" carry over into the world outside the lodge? ${ }^{24}$

In an era when differences of economic class were almost universally accepted as basic to the social order, Mary Ann Clawson, in Constructing Brotherhood: Class, Gender, and Fraternalism, noted "gentlemen... joined with merchants and craftsmen in a rite of leveling that ended in their symbolic elevation to the idealized status of Master Mason." 25 The ability to join the group depended "to a great extent on [the candidate's] financial solvency and his social status." 26 This raises the question of the group's openness to members of various economic backgrounds. The economic standing of the members will be examined in relation to their jobs, according to other studies on the relation between economic class and occupation. To what extent did that idea manifest

\footnotetext{
${ }^{23}$ James L. Gould, Guide to the Royal Arch Chapter: A complete monitor for Royal Arch masonry (New York: Macoy, 1886), 206

${ }^{24}$ Mark C. Carnes, Secret Ritual and Manhood in Victorian America (New Haven, CT: Yale UP, 1989), 3 .

${ }^{25}$ Mary Ann Clawson, Constructing Brotherhood: Class, Gender, and Fraternalism (Princeton, NJ: Princeton UP, 1989), 3. Italics from original text.

${ }^{26}$ Harriet W. McBride, "Fraternal Regalia in America, 1865-1918: Dressing the Lodges, Clothing the Brotherhood.” (Ph.D. diss., Ohio State University, 2000), 195.
} 
itself in Calumet Lodge 271 - how diverse was lodge membership in terms of class distribution?

The data for this study is derived from the Annual Reports of Calumet Lodge 271 of the Free and Accepted Masons. These reports provide the list of members, officers, and other information about Lodge operations. The members in both 1900 and 1920 were compiled into a spreadsheet, with their address, ethnicity, and occupation added from both the U.S. Census and Polk Directories, or phone books of the $19^{\text {th }}$ century America, that listed occupations and addresses. The list of members that were used in this study can be seen in Tables A.1 and A.2: List of Lodge Members in 1900 and 1920. At times the Census data and Polk Directories provided a different occupation, because the Polk Directories were taken at irregular intervals that did not correspond with the Census dates. When this happened the occupation listed in the Census was the one used for the purpose of this study. The Annual Reports also listed members from outside of the Copper Country, from California to New York. These members were discarded as outliers; they could not be found using local sources and likely joined Lodge 271 then moved to a different Lodge.

After the membership data sheet was built the Masons had to be assigned a class based on the attributes available for study. The most reliable attribute, or the one that covered the largest percentage of members, was their occupation as listed in the primary sources. In her article, “The Subjective Meaning of Social Class,” Mary Jackman sorted occupations into classes to understand the economic breakdown of the United States. Her study is reinforced by The Guided Age as a contemporaneous example. Sorting was 
applied to the members from 1900 and 1920 that provided insight into the class demographics derived from Jackman. This also allowed a study of the changes over the study period. Also in the data sheet the Lodge 271 brothers were plotted on the current street network to understand if there was any spatial relation of the members, did members live together or did members of similar classes occupy enclaves in the communities. When plotting the members the map was imposed over a 1917 Sanborn Maps of the vicinity. While originally used for fire insurance the maps provide layout and size of their houses and a relation to the larger industrial community. Through this study the members were sorted based on their occupation and plotted on the map in an effort to understand the effects of economic class on Masonic membership in Lodge 271. 


\section{Chapter 1: Fraternal Origins}

\section{Freemasons}

The lodge of the operative or practicing stonemasons was traced back to 926 C.E., when the lodges "attracted the attention of local dignitaries." ${ }^{1}$ These dignitaries wondered what traditions and practices took place behind the lodge doors. The lodges admitted those men of status, but to provide separate themselves and their operative brothers the dignitaries, they were given the title of an Accepted Mason. ${ }^{2}$ By the eighteenth century British and Scottish gentlemen "sought admission into the lodges of practicing stone masons," thus laying the foundation for the modern Masonic system. ${ }^{3}$ Through the patronage of gentlemen and those of means, the Accepted Masons added more symbolism to the practice "than those within" - the operative masons. ${ }^{4}$ This symbolism was adopted as a means to spread moral teachings through the use of Masonic allegories. The ritual illustrated symbols both in the lodge structure and the transformations through which the initiates passed on their way to a Master Mason. While the operative mason wore an apron to protect his clothing an Accepted Mason wore "his as 'a protection against the vices"," and a Mason was "oblig'd by his tenure, to obey the moral law" of his lodge. ${ }^{5}$

\footnotetext{
${ }^{1}$ Ferguson, Fifty Million Brothers, 19.

${ }^{2}$ Its possible they adopted the title as a way to signify they did not take part in the physical labor of masonry, but the spirit of the mason's labor.

${ }^{3}$ Clawson, Constructing Brotherhood, 3.

${ }^{4}$ Ferguson, Fifty Million Brothers, 19.

${ }^{5}$ Ibid, 19, Anderson, The Constitution of the Free-Mason, 49.
} 
The origins of the Free and Accepted Masons are shrouded in mystery. James Anderson's 1723 guide, The Constitutions of the Free-Masons, listed the first Mason as Adam. Clawson noted in Constructing Brotherhood that Anderson's document represented the "Grand Lodge's first attempt to define its organizational character and construct a meaningful history for itself." The knowledge Adam gained was necessary for the advancement of "mankind [and his Masonic] knowledge [was] confined to brethren who would cherish and preserve it." ${ }^{\prime 6}$ God created Adam, wrote Anderson, "after [his] image, the great Architect of the Universe" who passed the Masonic teachings down to Noah. ${ }^{7}$ The Masonic idea, but not the physical lodge itself was traced back to Adam and King Solomon, through the cathedral builders of Europe. In constructing Solomon's Temple, Hiram Abiff the temple's main architect, divided the workers into three classes - entered apprentice, fellow crafts, and masters of the work this and "historical division of labor" set the precedent for the Freemason's first three degrees..$^{8}$

In America the Masonic lodges moved westward with the colonists into the continent. The British Masons organized the first lodge in the 1730s, including various Provincial Grand Lodges. The lodges also came with the military, even though ““military lodges” were forbidden by English General Law Regulations to admit or

\footnotetext{
${ }^{6}$ Charles W. Ferguson, Fifty Million Brothers: A Panorama of American Lodges and Clubs (New York: Farrar \& Rhinehart, 1937), 17.

${ }^{7}$ James Anderson, The Constitution of the Free-Mason. Containing the History, Charges, Regulations, etc. (Philadelphia, 1734), 12.

${ }^{8}$ William D. Moore, Masonic Temples, Freemasonry, Ritual Architecture, and Masculine Archtypes (Knoxville, TN: University of Tennessee Press, 2006), 4.
} 
make masons of any but "military men of rank" - i.e. above the rank of privates. ${ }^{9}$ So while military lodges were allowed, they were organized by class in terms of military rank and not officially open to every man in the post. However while the regulation forbade privates from joining, the troops did not always heed the regulations. Thus the military was one of the primary means of conveying the Masonic brotherhood.

The organization of the Grand Lodge of the Territory of Michigan took place on June 28, 1826, with the officers of the lodge installed by Lewis Cass, Past Grand Master of the Grand Lodge of Ohio. The Grand Lodge of Michigan was founded in a "lively interest in the prosperity of the Grand Lodge of Michigan and [to] promise... fraternal aid and invite the most friendly interchange of communication" and to help in the further growth of the fraternal order. ${ }^{10}$ Within this setting American Masons improved the Masonic guidebook used in Michigan. The nineteenth century works of Thomas Smith Webb, ritualist and premier Masonic lecturer, condensed Preston's Illustrations of Masonry to "better suit the needs of American lodges" in his work, the Freemason's Monitor or Illustrations of Freemasonry. ${ }^{11}$ Webb's edits completely reworked the rituals and "contained little that was original," and added more degrees to the everexpanding Scottish Rite and chivalric rites. The chivalric outgrowth led to the 1816 founding of the Grand Encampment of the United States of the Knights Templar. However not until 1855 was the 'Star of the East,' later known as the Order of the

\footnotetext{
${ }^{9}$ Jefferson S. Conover, Freemasonry in Michigan: a comprehensive history of Michigan from its earliest introduction 1764 (Coldwater, MI: Conover Engraving and Printing Company, 1884)12.

${ }^{10}$ Jefferson S. Conover, Freemasonry in Michigan, 36.

${ }^{11}$ John D. Hamilton, Material Culture of the American Freemason, (Lexington: National Heritage Museum, 1994), 5.
} 
Eastern Star, created for daughters, wives, unmarried sisters, or mothers of Master Masons. ${ }^{12}$

\section{American Fraternalism}

The professed purpose of fraternal groups was to "alleviate suffering, to inculcate good morals, loyalty to country, and [for members] to do good unto others." 13 In 1896 the top fraternal groups - Odd Fellows, Freemasons, Knights of Pythias, and Improved Order of Red Men had membership totaling over two and a quarter million men. In 1907 Stevens' Cyclopedia of Fraternities noted that " 40 per cent. of the present male population" was actively engaged as members of fraternal societies. In his guide Stevens listed more than three hundred and fifty active groups. ${ }^{14}$ Masonic Lodges offered fellowship and friendship in the Copper Country and a "means of conciliating true friendship among persons. ${ }^{, 15}$ In the vicinity of Calumet Township numerous men of status were Masons, including James McNaughton, General Manager of Calumet and Hecla, and John D. McKinnon, a physician at the Calumet and Hecla Hospital. Other members in 1920 were Alex N. Wilson and Ernest Stevens, both machinists working for the copper mines, and Samuel Jess, who worked as a trammer for Calumet and Hecla. This group of members allowed the formation of social networks that "link[ed] people into solidarity units" within the larger community through the common connection of brotherhood. $^{16}$

\footnotetext{
${ }^{12}$ Hamilton, Material Culture of the American Freemason, 5.

${ }^{13}$ M. Stevens, Cyclopedia of Fraternities (Forence, KY: Gale Group, 1980), xxii.

${ }^{14}$ Stevens, Cyclopedia of Fraternities, xvi.

${ }^{15}$ Anderson, The Constitution of the Free-Mason, 48

${ }^{16}$ Clawson, Constructing Brotherhood, 90.
} 
When the men gained entrance into the lodge they "symbolically became craft workers;" the lodge became a place where "workers rubbed shoulders with merchants, bankers, and politicians" in one fraternal body. ${ }^{17}$ The men who joined the lodge entered into the group setting, and into a bonding organization. Robert Putman, in Bowling Alone, defines bonding as "tending to reinforce... identities and homogeneous groups. ${ }^{18}$ The Lodge took a diverse membership body and professed to make them "brothers upon the same level." The men were primarily English, Scottish, Canadian and American, with smaller percentage of men from other nationalities. The rituals and brotherhood removed men from the outside world, and placed them within the secure setting of the lodge. The Freemasons provided a cohesive social network for new members that allowed people to make contacts, "cultivate credit sources," and gain access to a network of lodges that helped with employment as Americans became increasingly mobile. ${ }^{19}$ All of this depended on the initiate's successful application to join the lodge, and in his ability to pay the dues and membership.

As noted by Jacob Katz, in his article The Fight for Admission to Masonic Lodges, "in theory...membership was open to everyone, irrespective of his class or religion. ${ }^{20}$ According to Masonic monitors from the time there were only two types of requirements to join a lodge - internal and external qualifications. The internal qualifications included that a man sought membership "of his own free will and accord

\footnotetext{
${ }^{17}$ Rhonda R. Levine and Scott G. McNall, Bringing Class Back In: Contemporary and Historical Perspectives (Greely, CO: Westview Printing and Graphics, 1991), 102.

${ }^{18}$ Robert Putman, Bowling Alone: The Collapse and Revival of the American Community (New York: New York, 2001), 21.

${ }^{19}$ Carnes, Secret Ritual and Manhood, 2.

${ }^{20}$ Jacob Katz, "The Fight for Admission to Masonic Lodges," Leo Baeck Institute Yearbook, 11, no 1 (2000): 171.
} 
[and] prepared for the ordeal in his heart" before he sought entrance to the lodge. ${ }^{21}$

Externally, the "very first pre-requisite to initiation, [was] that the candidate [had to] be 'a man';" he must believe in God as "one of the unwritten Landmarks" of Masonry; and lastly be twenty-one years old. ${ }^{22}$ In theory men from every class could apply for membership in the lodge. They proclaimed a "disregard for social and economic position" of the prospective members. ${ }^{23}$ These were the basic requirements for brotherhood. In reality, however "admission was dependent on the decision of the existing lodge members.",24

${ }^{21}$ Drew, The Freemason's Handbook, 19.

${ }^{22}$ Ibid, 21-23.

${ }^{23}$ Mary Ann Clawson, "Fraternal Orders and Class Formation in the Nineteenth-Century United States," Comparative Studies in Society and History, 27, no. 4 (October 1985), 672

${ }^{24}$ Katz, "The Fight for Admission," 171. 


\section{Chapter 2: Masonic Auxiliaries}

\section{Background}

The Masons offered membership to those who sought a "means of achieving distinction in Masonry" to both women and to men. ${ }^{1}$ The first three degrees (Entered Apprentice, Fellowcraft and Master Mason) collectively were known as the Blue Lodge and provided an entrance to Masonry. Men who sought a more elite membership could apply to auxiliary organizations "commonly known as 'higher bodies'.,2 The most common bodies men joined were the Royal Arch Masons and the Knights Templar. Both were "perceived as elite groups...characterized by elaborate rituals and celebrations" by the general population and fellow Masons. The higher degrees attracted a large following; the Royal Arch and Knights Templar extended the Masonic secrets above the established Blue Lodge through myriad higher degrees. Another popular order established by Masons was the Order of the Eastern Star, or O.E.S. The O.E.S. bestowed Masonry upon the wives, mothers, and unwed daughters of Master Masons. Because most Masons rose to the third degree, they and their female relations were eligible for membership in the O.E.S. The Order of the Eastern Star was a true auxiliary, for its female members did not have the right to join a Masonic Lodge.

\footnotetext{
${ }^{1}$ Lynn Dumenil, Freemasonry and American Culture (Princeton, NJ: Princeton UP, 1984) 15.

${ }^{2}$ Ibid, 15.
} 


\section{Knights Templars}

The Knights Templar traced their history through both fact and legend; they maintained the "connection between Freemasonry and the Land of Solomon."3 The Commandery is the basic subdivision of the Knights Templar, comparable to the Masonic Lodge. Early Commanderies were organized ad hoc and after applying the “essential tests" to other Templars, a new Commandery could be constituted. ${ }^{4}$ In July 1816 eight Councils and Encampments assembled in New York, and "formed, adopted and ratified" a constitution. ${ }^{5}$ It was from this gathering that the Knights Templar as practiced in 1900 was organized in the United States. The spirit of the chivalric body was transferred to the Masons as the Knights expressed it though the " 30,000 swords... of five hundred" American Commanderies. ${ }^{6}$ Some of the elected officers were "of first rank in social...importance," which would continue with the various Commanderies as they were organized across the United States. ${ }^{7}$ One of these Commanderies was Montrose Commandery No. 38 from Calumet, MI, organized in October of 1885. It operated under a dispensation from the Grand Encampment of Michigan until it was granted a charter on May $11,1886 .^{8}$

Unlike Masonic lodges that drew from a limited geographic area, such as a city or neighborhood, the members of Montrose Commandery were drawn from Master

\footnotetext{
${ }^{3}$ Charles G. Addison, The History of the Knights Templars (Kempton, IL: Adventures Unlimited Press, 1997), 11.

${ }^{4}$ Ibid, 573

${ }^{5}$ Ibid, 574 .

${ }^{6}$ Ibid, 12.

${ }^{7}$ Ibid, 575 .

8 "Montrose Commandery," Calumet Evening News, undated article. Copper Country Vertical File, MTU $\& \mathrm{CCHC}$.
} 
Masons throughout the Copper Country. The majority of the membership hailed between the two villages of Houghton and Calumet but Willard Smith of Mohawk and James Mercer of Ontonagon were also members. The officers of the early group included the area elite such as John Duncan as Eminent Commander, Frank A. Douglas as Generalissimo, Edward F. Douglas as Captain General, F.J. Downer as Prelate, and W.A. Dunn as Treasurer. The Commandery was first organized in Hancock and met at the "old Masonic temple on Hancock Street" once a week. ${ }^{9}$ In 1889 the Commandery moved to Calumet and met at the newly completed Union Building in the same room as the Masonic Lodge 271, from which a majority of its membership was based. The Montrose Commandery was "an active and enterprising body," which during its existence had been represented either in its entirety or by representatives at national and state conclaves. ${ }^{10}$ In their 1895 trip to the triennial conclave in Boston they were accompanied by the Calumet and Hecla Band; this created a "marked impression" among those in attendance. ${ }^{11}$ The group grew to such an extent that in 1906 about fifty members left to form Palestine Commandery in Houghton. One thing of note however were the dues and fees required of members in the Commandery as seen in their ByLaws:

"Sec. 2. No person shall receive the Orders of Knighthood in this Commandery for a less sum than fifty dollars, which shall accompany the petition, and shall be refunded in case the petitioner is rejected.

\footnotetext{
9 "Montrose Commandery," Calumet Evening News.

${ }^{10}$ Ibid.

${ }^{11}$ Ibid
} 
An equipment fee of fifty dollars shall be paid by the candidate before he can receive the Order of Knights Templar, which shall be refunded when he has satisfied the Captain General that he has provided himself with the Regulation Uniform as per Article VIII of these By-laws." ${ }^{, 12}$

The uniform consisted of a "black regulation frock coat, black pantaloons, belt, sword, and chapeau, buff gloves, white standing collar, and white neck tie for full dress." Their fatigue dress was the "same as full dress, except for chapeau a black cloth cap, navy form, with appropriate cross in front and gloves." A majority of the population could not pay the one hundred dollars required to join the Knights Templars. ${ }^{13}$ The application and uniform fees were apart from the annual five-dollar dues, to be paid "at or before the Stated Conclave preceding Good Friday.” Also to remain a member of the Knights Templars he had to a member in good standing of a Masonic lodge. This good standing involved paying dues in a Masonic Lodge, so Knights had to roughly pay twice the fees of an average Mason to be a member of a Commandery. The Knights were seen traditionally as the "most distinguished Masonic order." ${ }^{\text {"14 }}$ For the cost of membership the organization offered membership among like-minded individuals, knights of faith, and arguably the economic elite of Copper Country society.

\footnotetext{
${ }^{12}$ By-laws and list of members of Montrose Commandery no. 38 Knights Templar : organized by dispensation from the Grand Commandery of Michigan, June 11, A.D. 1885, A.O. 767; chartered May 11, 1886, A.O. 768; adopted 1903. (Calumet, MI: Montrose Commandery, 1903), 4. [Accessed at Michigan Technological University, call number HS445.M5 K58]

${ }^{13}$ Ibid, 8.

${ }^{14}$ Dumenil, Freemasonry and American, 16.
} 


\section{Order of the Eastern Star}

Another auxiliary group to Masonic Lodge 271 was the Order of the Eastern Star. The Masons founded the Order of the Eastern Star as a women's auxiliary to their order, open to both men and women. The men had to be Master Masons and in good standing with a Lodge in order to join the Order of the Eastern Star. The General Grand Chapter of Michigan was organized in 1878, with the Calumet Constellation 182 instituted on June $10,1896 .{ }^{15}$ By 1907 total membership in the organization had risen to 160,000 in the United States and a total of 200,000 around the world. ${ }^{16}$ Stevens' Cyclopedia of Fraternities mentioned "this Order is not Freemasonry, and is in no way connected with it" and he was partially correct. It was a Masonic body although the ritual and "mysteries [were] no part of Masonry.""17 The O.E.S. was independent from Masonic organization, and yet only Master Masons and their immediate female relatives could apply for membership. The first manual for the order referred to the group as "adoptive Masonry" or "Adoptive Rite of Female Freemasonry" although the second title fell out of use. ${ }^{18}$ It was created as a separate order and afforded the women no "connection or right of membership in a Masonic lodge." "It afford[ed] no especial means by which women members may prove themselves relatives of Freemasons, except to Freemasons who are members of the Order of the Eastern Star."19 The Order

\footnotetext{
${ }^{15}$ William C. Hollands, The Eastern Star of Michigan, 1855-1942 (Ann Arbor, MI: Edwards brothers, Inc., 1942), 126. The Constellation is the basic division of the O.E.S., comparable to the Masonic Lodge.

${ }^{16}$ Stevens, Cyclopedia of Fraternities, 98.

${ }^{17}$ Ferguson, Fifty Million Brothers, 310.

${ }^{18}$ Robert Macoy, Manual of the Order of the Eastern Star (New York: Masonic Publishing and Manufacturing Co, 1865), 1.

${ }^{19}$ Stevens, Cyclopedia of Fraternities, 98.
} 
of the Eastern Star was acted as a social group that brought the wives of Masons into a Masonic body.

Within the context of the Order of the Eastern Star, class was important for membership, however eligibility was not based on the female members themselves. Within the Eastern Star constellation, eligibility was determined by the woman's male relation, through which "women [were] defined and recognized only in terms of their relationships" to both the family and the patriarch. ${ }^{20}$ A lady's social or economic position did not determine eligibility, but her husband's accepted status as a Master Mason. Within the Eastern Star constellation the Grand Patron, who was a Master Mason, was the highest ranking officer, with the "right to preside at meetings and appoint all committees," while the Grand Matron, the highest ranking woman officer, was "to assist him [the Grand Patron] in his duties." ${ }^{21}$ Not until the 1870s did the Grand Matron began to replace the Grand Patron as the head of the constellation, and only on a state-by-state basis.

However the O.E.S. was envisioned by Robert Macoy, who wrote the Order's original ritual, to "enable them [the ladies adopted into the Masonic communion] to express their wishes, and [give] satisfactory evidence of their claims, in a manner that no stranger to the Masonic family [could] do."22 The Order, like the Masons, was steeped in symbolism centered on the Bible. The Order also used a five-pointed star, or "signet of Solomon." Each of the five points stood for the five moral aspirations of

\footnotetext{
${ }^{20}$ Clawson, Constructing Brotherhood, 195.

${ }^{21}$ Ibid, 202.

${ }^{22}$ Macoy, Manual of the Order of the Eastern Star, 5.
} 
members - "the binding force of a vow," "devotion to religious principles," "fidelity to kindred and friends," "faith in the power and merits of the Redeemer," and charity. ${ }^{23}$ In order for a constellation to be constituted or degrees to be conferred "not less than five ladies who are entitled to receive, or have received the degrees" had to be present. ${ }^{24}$

It was not the Masons wishing to share their rituals and secrets that led to the formation of the Order of the Eastern Star. The Masons organized the Order of the Eastern Star to check further opposition because "ladies sometimes [took] umbrage against Masonry, and even [became] its enemies, and [opposed] it violently." ${ }^{25}$ The wives of Masons wondered how they could trust their husbands if they "refused to share its [Masonry's] secrets." Many Masonic editors suggested that the "veil of secrecy" be pulled back "just far enough to allay women's fears. ${ }^{, 26}$ Masons founded the O.E.S. to provide "a little knowledge, of the real nature and purposes of Masonry" and to "remove all this [hostility] in the mind of any lady present" in the constellation. Macoy stated that the Masons placed "great value upon their degrees" and the lodge meeting made the men "better, wiser and happier." He explained that Masonry meant so much to the men, through the O.E.S. the ladies "too [would] love Masonry."27 Through their connection to Masonry "the hand of relief [was extended] out toward" the ladies in a time of need. The Order provided them "all the advantages of the society... [without] any of the labor or expense of sustaining it." The only Masonic privilege denied to

\footnotetext{
${ }^{23}$ Stevens, Cyclopedia of Fraternities, 98.

${ }^{24}$ Macoy, Manual of the Order of the Eastern Star, 7.

${ }^{25}$ Macoy, Manual of the Order of the Eastern Star, 14.

${ }^{26}$ Dumenil, 81-82.

${ }^{27}$ Macoy, Manual of the Order of the Eastern Star, 15.
} 
female members of the O.E.S. was "that of visiting the lodge." 28 The reason given for Masonry's unwillingness to accept female members is seen in the rules of the lodge, which remained unchanged for "thousands of years." ${ }^{, 29}$ Each Mason "pledged himself...that he would never allow any of the ancient rules" to be changed. The Order of the Eastern Star gave the female members "some perfect, modest and proper, easily practiced and easily understood" way for members to display their Masonic attachment. ${ }^{30}$ Because women's membership was dependent on their husband however, their class likely corresponded with their husbands and the Order of the Eastern Star probably had similar class divisions to the Masonic Lodges.

The opening and closing ceremonies of the constellation unified members "in bonds of sisterhood." The repeated enactment of the ritual provided the members the values "deemed most worthy of emulation." However unlike the Masonic rituals the initiate was "neither blindfolded nor dressed differently." The Order of the Eastern Star acted as a social gathering with less of the ritualized transformation seen in the Masonic Lodge. ${ }^{31}$ The reason given for the lack of Masonic ritualistic transformation was because women "represented the highest [moral] type to which men aspired," they had no reason to undergo a ritual. ${ }^{32}$ During the initiation, an O.E.S. member guided the candidate around the lodge and vouched for her worthiness. Order of Eastern Star constellations formed near existing Masonic Lodges, and the Copper Country constellation drew from multiple lodges and a wider area. In 1896 when the Calumet

\footnotetext{
${ }^{28}$ Macoy, Manual of the Order of the Eastern Star, 16.

${ }^{29}$ Ibid, 17.

${ }^{30}$ Macoy, Manual of the Order of the Eastern Star, 18. Italics in original.

${ }^{31}$ Clawson, Constructing Brotherhood, 196-197.

${ }^{32}$ Dumenil, Freemasonry and American Culture, 84.
} 
Chapter was instituted, Mary N. Webber served as Worthy Matron with William M. Harris as Worthy Patron. Chapter 182 was the only Order of the Eastern Star Constellation in the Copper Country until the Houghton Constellation was organized in December 1901 and the Hancock Constellation in September of $1909 .{ }^{33}$ Within the O.E.S. the basic unit of the order was the constellation, comparable to the Masonic Lodge. Women who sought membership in the Order therefore had to travel to Calumet for the first few years of its existence in the Copper Country. ${ }^{34}$ Mary Webber was most likely related to a Master Mason in one of the other Masonic lodges, as there is no Webber appearing in the 1899 Annual Report for Calumet Lodge 271. While important, race and gender are not considered within this study because the group was an all-male, with membership drawn predominately from Northern Europeans - especially the British Isles.

\footnotetext{
${ }^{33}$ Hollands, The Eastern Star of Michigan, 144.

${ }^{34}$ Ibid, 146 \& 157.
} 


\section{Chapter 3: Membership Motivation and Costs}

\section{The Golden Age of Fraternalism}

W.S. Harwood defined the period from 1870-1910 as the "Golden Age of Fraternities," during which the Masons became one of the most popular fraternal groups in the United States - with over 750,000 members in $1897 .{ }^{1}$ This included the members of the Knights Templar, Scottish Rite, Royal Arch Masons and other auxiliary groups affiliated with the Masons. Its multifaceted appeal prompted men from various social groups to seek membership. The lodge had many reasons that caused it to be popular in late nineteenth and early twentieth century America. One of the reasons for the popularity of the order was evident through the visual displays of membership, with "men proudly [wearing] the Masonic symbol," to parades and public events.

Businessmen, politicians and clergy lent their respectability to the organization. ${ }^{2}$ Men could shop in official lodge supply catalogs to procure their robes, lodge furniture, fixtures, and everything needed in a modern Masonic lodge. The Sears, Roebuck and Company also sold 'Secret Society and Emblem Charms' in their 1902 catalog, including a "Blue Enameled, gold-filled Masonic" emblem priced at \$1.75, with a solid gold version of the same emblem also available for $\$ 3.75$. They also sold a "Gold filled emblem set in black onyx," a "Gold filled Masonic and Odd Fellows" emblem and a "Solid gold, hard enameled, engraved" emblem of the Order of the Eastern Star. All of these could be purchased from between $\$ 1$ to $\$ 4$, plus three cents shipping. ${ }^{3}$ (See Figure

\footnotetext{
${ }^{1}$ W.S. Harwood, "Secret Societies in America," North American Review 164 (May 1897), 9.

${ }^{2}$ Dumenil, Freemasonry and American Culture, 7-8.

${ }^{3}$ Sears, Roebuck, and Co. Catalog (Chicago: Sears, Roebuck and Company, 1902), 145.
} 
3.1) The men who became Masons were able to join, officially, "without regard to religion, nationality, or class" and the candidate had to agree to "[live] a moral life."4 A majority of members were Christian. Although officially open to everyone, irrespective of their religion (including Jews and Muslims) the religious aspect of the ritual tended to exclude non-Christians. This did not extend to Catholics, as Pope Clement XII in In Eminenti forbade Catholics from joining under threat of excommunication. This was due to the religious character of the lodge, the church worried the men might pay more

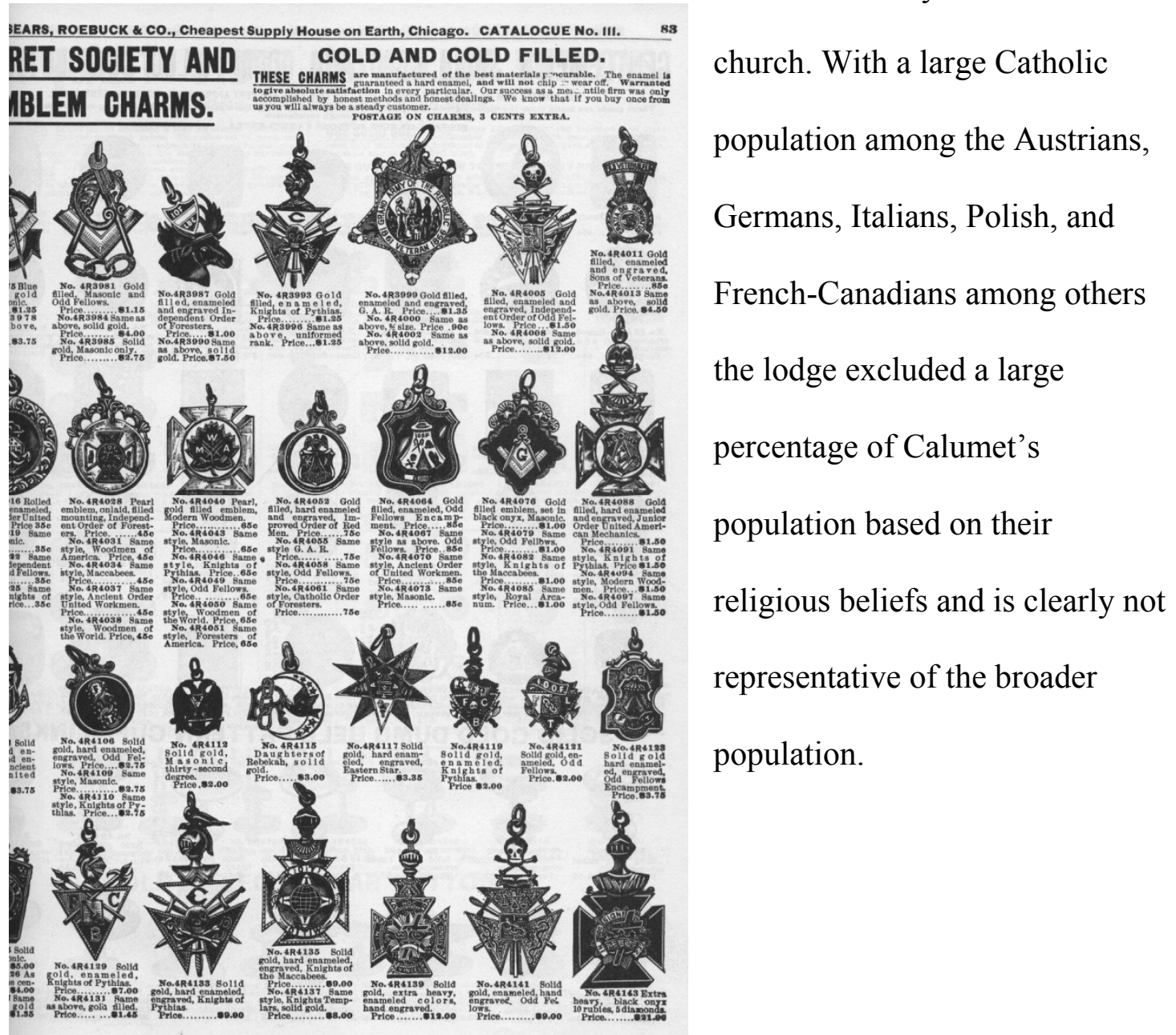

Figure 3.1: Sears, Roebuck, and Company advertisement for Masonic charms. Sears, Roebuck, and Co, Secret Society and Emblem Charms. ${ }^{4}$

${ }^{4}$ Sears, Roebuck and Company, 83. 
Men had other reasons for joining, including the order's structure, prestige, "financial aid, business and political connections, entertainment, and sociability." 5 Often the lodge meeting was also one of the few activities that took place on lodge night. Also the members "felt a strange and powerful attraction" to the ritual and lodge membership. ${ }^{6}$ For the great number of middle and working class members, the lodge offered an opportunity to achieve distinction. Another reason a man might seek membership was financial aid. Lodges sometimes offered charity to fellow members and their families. Lodge 271 had a Committee of Charity with the power to "draw orders on the Treasurer for any sum not exceeding five dollars for the relief of any one applicant." This relief fund later increased to ten dollars by 1906 and twenty-five dollars in $1923 .{ }^{7}$ By joining a lodge in one location the member was able to receive assistance wherever a lodge was in place. New members took an oath to aid "brethren and their brethren's dependents in time of need." "If a Mason could not help a brother in need, they were to direct him to someone who could provide assistance. Masonic charity also included visits to sick brothers so they would be reminded of this fraternal support. During the "Charge at Opening," or opening ceremony, the members were reminded to "[cultivate]... an active benevolence." Again during the "Charge at Closing," Masons promised to "befriend and relieve every brother who shall need... assistance." Members were to "do good unto all.",

\footnotetext{
${ }^{5}$ Dumenil, Freemasonry and American Culture, 14.

${ }^{6}$ Carnes, Secret Ritual and Manhood, 2.

7 "By-laws of Calumet Lodge 271," 1870-1923, 5.

${ }^{8}$ Drew, The Free-mason's Handbook, 26.

${ }^{9}$ Ibid, 31.
} 
During a Masonic burial all the Lodge members wore evergreen sprigs on their lapel symbolizing eternal life and that the Masons that passed on would not be forgotten. The Masons extended burials and funerals to both local and "out-of-town Masons who had died away from home." 10 The Grand Lodge of Michigan published the members' names and Lodge of deceased Masons each year in their annual report to ensure that a member would be remembered. Lodge membership instilled in members a sense of importance and it formed a bond between brothers. The lodge reinforced this bond through the Masonic rituals, with the aura of a Masonic Temple providing a churchlike backdrop for meetings. ${ }^{11}$

\section{Application and Ballot}

To take part in the rituals, a man had to make himself a "Candidate for the Mysteries of Masonry" and have personal recommendations from two Masons. In 1873 the applicants had to list the lodge they wished to apply to, their city of residence, occupation, and the names of two members recommending them (See Figure 3.2, an application to join Calumet Lodge 271.) ${ }^{12}$ The applicant then would "be presented at a regular meeting, and if received, be referred to a committee of three members for inquiry and report." His application then laid over "until the next regular meeting." One month after he submitted his application the Lodge informed the candidate of their decision. The candidate would be admitted to the Lodge only if a "unanimous vote [was] had in favor of the applicant for each degree," and even if accepted into the Lodge

\footnotetext{
${ }^{10}$ Dumenil, Freemasonry and American Culture, 19.

${ }^{11}$ Ibid, 31.

${ }^{12}$ Petition to Join Lodge 271, Copper Country Masons, Acc. \# 0035. Box 48, Folder 3. MTU \& CCHC.
} 
as an Entered Apprentice his advancement to Master Mason was not guaranteed. ${ }^{13}$ The Masons voted by means of casting marbles into a ballot box, white for yes and black for no. (Figure 3.3). ${ }^{14}$ In case one member voted in errors, a "second ballot [could] be taken, but in no case [should] a third ballot be had" to "rectify the possible mistake.",15

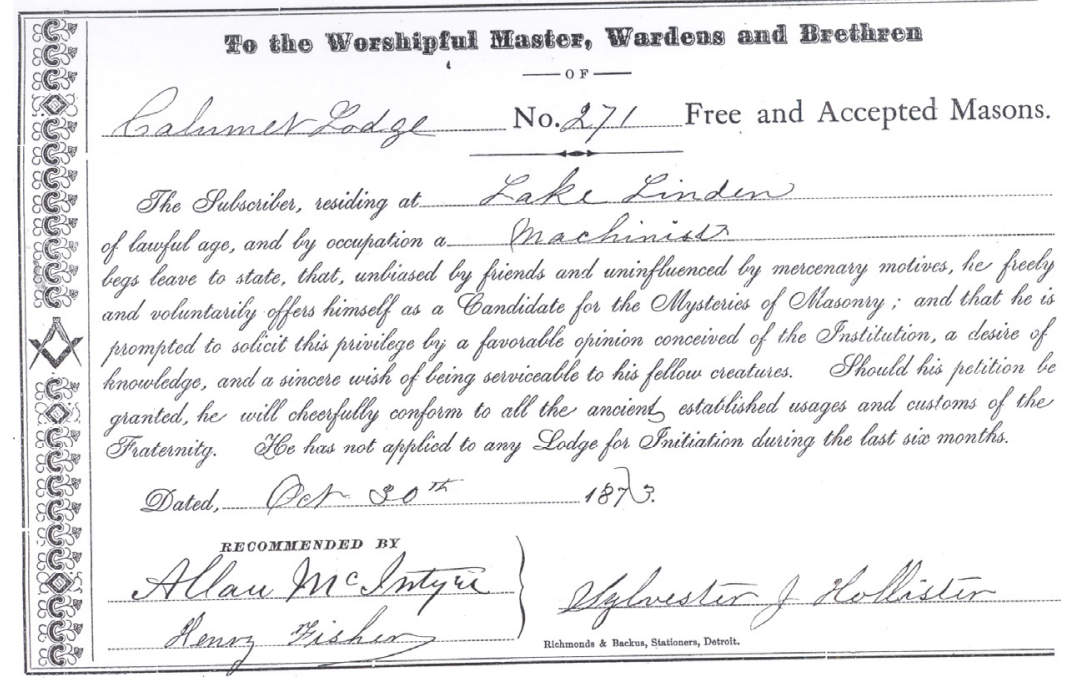

Figure 3.2: Application to Join Lodge 271. Figure from Michigan Tech Archives and Copper Country Historical Collections. ${ }^{12}$

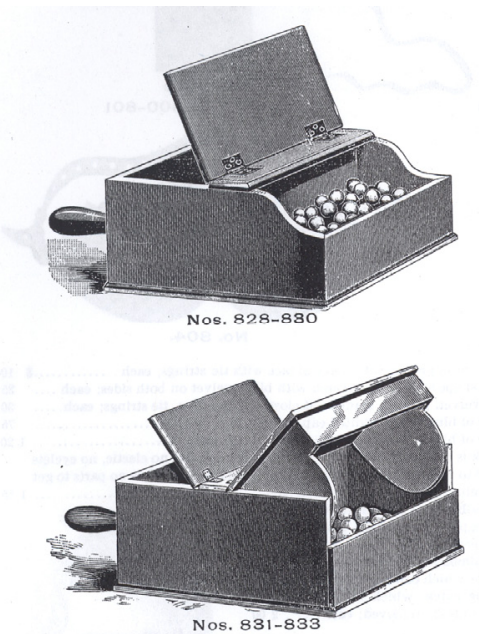

Figure 3.3: Masonic Ballot Boxes. Figure from The Henderson-Ames Company, Ballot Boxes. ${ }^{14} \mathrm{~A}$ ballot box nearly identical to the one used by Lodge 271

13 "By-laws of Calumet Lodge 271," 1870, 6.

${ }^{14}$ The Henderson-Ames Company, Manufacturers of Masonic Lodge Supplies (Kalamazoo, MI: The Henderson-Ames Co. 1902), 54.

15 "By-laws of Calumet Lodge 271," 1870, Acc. \# 035, Box 46, Folder 1, MTU \& CCHC, 4., "By-laws of Calumet Lodge 271," 1906, Acc. \# 035. Box 46, Folder 2. MTU \& CCHC, 9. 
Many men also joined the lodge because of the growing prestige associated with membership. Theodore Ross, an Odd Fellow historian writing in the nineteenth century, noted that membership came from "the great middle, industrial class." "16 The industrial class joined the Odd Fellows in 1870 when the average industrial worker earned thirty to forty dollars a month. The fee to advance from Earned Apprentice to Master Mason totaled twenty-five dollars plus the annual three dollar due. This put membership out of many workingmen's reach. ${ }^{17}$ During the 1880 s the fees needed for advancement to the rank of Knights Templars, stood at a low of \$75 in New York to \$230 in San Francisco; these fees did not include the cost of uniforms and jewelry. The Blue Lodges in America complained that these groups "undermined the egalitarianism of Masonry" as these higher orders "allowed...feathers and titles to destroy the democracy of [Masonry] and convert it into a system of castes." "18 These higher orders were an exception to the egalitarian nature of the Masonic Lodges. While some of the members joined the Lodge to gain entrance into the higher orders for a majority of the Masons the cost prohibited that. With its lower application costs and dues the Blue Lodge accepted a more reflective representation of the different economic classes in Calumet. However this depends on the definition of class and how it relates to occupation. Economic class could be based on the level of income or the individual's occupation. ${ }^{19}$

\footnotetext{
${ }^{16}$ Carnes, Secret Ritual and Manhood, 4.

17 "By-laws of Calumet Lodge 271," 1914, Acc. \# 035. Box 46, Folder 3. MTU \& CCHC, 8.

${ }^{18}$ Dumenil, Freemasonry and American Culture, 17.

${ }^{19}$ Wilbert E. Moore, Industrial Relations and the Social Order (Kansas City: Macmillan Company, 1946), 569.
} 
The records from Lodge 271 shed more light on this financial cost, with the initial cost in 1870 of fifteen dollars: five for "admitting to membership" and ten for the Entered Apprentice degree ${ }^{20}$ If the Lodge rejected the candidate, it would return his application fees. By 1923 Lodge 271 charged five dollar dues, and fifty dollars were needed to raise a member from Entered Apprentice to Master Mason. This made it difficult, purely on economic terms for the working class men to join the lodge. Membership also depended upon a member's behavior, and the lodge had two main routes to remove a brother from the Lodge. He could fail to pay his dues and be suspended for such non-payment. ${ }^{21}$ Non-payment of dues was the most common cause of suspension in Lodge 271. On average one member was suspended each year from 1899-1920, with a high of eleven suspensions in $1914 .^{22}$ Also the lodge could be expel a member for un-Masonic conduct if the charges of misconduct had been written out and filed to the Secretary. This course of action was not taken in Lodge 271, at least not which showed in the Annual Returns from 1899 to $1920 .^{23}$ The secretary "furnish[ed] the accused brother a copy thereof at least ten days previous to the trial." The whole testimony could be "reduced to writing...giving the Master of the Lodge three day's notice" if the accused wanted to appeal the decision. If the un-Masonic conduct, such as marital infidelity or drunkenness, occurred outside the jurisdiction of the Lodge in

\footnotetext{
20 "By-laws of Calumet Lodge 271," 1870, 3.

${ }^{21}$ Ibid, 5. "Within a reasonable time thereafter, [if he did] not remove the suspension by the payment of dues, he may be expelled."

22 "Roster of Calumet Lodge 271," 1911 \& 1920, Acc. \# 035. Box 46, Folders 6 \& 9. MTU \& CCHC.

23 “Annual Returns Calumet Lodge 271," 1900 \& 1920, Acc. \# 035. Box 46, Folders21 \& 25. MTU \& CCHC.
} 
which the charges were filed, they were to be forwarded to the "Secretary of the Lodge within whose jurisdiction the accused at the time resides. ${ }^{24}$

If the member was found guilty of un-Masonic conduct he could, within ninety days, make an appeal to the Grand Lodge by submitting a certified copy of the "proceedings had in his case, with the original testimony." 25 In the surviving documents this course of action was not taken between 1899 and 1920 in Lodge 271. However in the 1840s-1860, the Annual Report of the Grand Lodge of Michigan listed ten to sixteen members expelled for un-Masonic conduct each year, with marital infidelity the most common reason for expulsion. The Grand Lodge of Michigan expelled thirteen members in 1899 for un-Masonic conduct, and also listed five pages of suspensions for non-payment of dues for the entire state. ${ }^{26}$

Due to a lack of surviving records it cannot be said who was expelled or had their application to join Lodge 271 rejected. If these records survived it would provide an interesting facet to the study; if those rejected or expelled came from particular economic or ethnic backgrounds. By understanding the application process and who the Masons chose to accept into their Lodge light would be shed on how egalitarian the brothers were by who they welcomed into their ranks. The applications would also illuminate the equality of the organization. The applicants also had to be recommended by two current brothers, and there is a possibility that an applicants success depended on who vouched for their Masonic character.

\footnotetext{
24 “By-laws of Calumet Lodge 271," 1870, 6-7.

25 "By-laws of Calumet Lodge 271," 1870, 7.

${ }^{26}$ Transactions of the Grand Lodge of the State of Michigan (Detroit: Free Press Book and Job Printing House, 1899), 237.
} 


\section{Chapter 4: A Means of Respectability}

\section{Social Relations}

"In no country in the world, has the principle of association been more successfully used or applied to a greater multitude of objects than in America.

There is no end which the human will despairs of attaining through the combined power of individuals united into a society"

Alexis de Tocqueville, Democracy in America, 1847

In 1897, the number of fraternal lodges in America stood at 70,000. Numerically massive, the lodges provide an insight into the social relations in late-nineteenth century America. ${ }^{1}$ The lodge setting provided means through which the social relations between individuals could be examined. The Masons expressed their equality between members and their disregard of social standing. Anderson wrote in The Constitution of the Freemason that "all Masons are brethren upon the same level.", The members of Lodge 271 were generally anything but typical wageworkers of their time however. This stands in contrast to the idea that some groups were "an organ of lower-middle class

respectability."3 Wageworkers generally took up membership in the Knights of Labor or the Odd Fellows. Men with the means to do so joined the Masons, but the Masonic lodge still provided a means for Copper Country working and middle class men with

\footnotetext{
${ }^{1}$ Clawson, Constructing Brotherhood, 88.

2 Anderson, The Constitution of the Free-Mason, 54.

${ }^{3}$ Clawson, Constructing Brotherhood, 95.
} 
disposable income an avenue to socialize on lodge night. ${ }^{4}$ Many workers embraced respectability "as a key component of their complex identities" and while Historian Andrew August wasn't specifically discussing the Masons, through membership in the Lodge it allowed them to "define themselves as respectable. ${ }^{5}$ Unless however the applicant was precluded from joining based on personal beliefs such as religion as Catholics.

The Calumet Masons can be examined through Census records that listed personal information such as occupation and presence of household servants. Variability in these categories indicated a varied class membership for Lodge 271 and provided a means to understand a member's economic class. While members of the lodge came from different economic backgrounds, they "behaved towards each other as social equals." ${ }^{\prime 6}$ One fact that is true with Calumet and Laurium is there was less of a spatial distinction between economically based neighborhoods. As noted by Sean Wilentz in his thesis, "in smaller single-industry cities and mining towns, divisions between workers and the independent middle classes tended to be less sharp than in larger cities." 7 This lack of economic class division was reinforced in the Laurium National Historic District nomination. In a mining community with a constant influx of residents the boundaries between 'low' and 'middle' classes, and to some extent the 'upper-middle' class were fluid and at times hard to define. This is also true from a spatial aspect by looking at where the members of Lodge 271 lived in the area. Class is

\footnotetext{
${ }^{4}$ Clawson, Constructing Brotherhood, 96.

${ }^{5}$ Andrew August, The British Working Class: 1832-1940 (New York: Pearson Longman, 2007), 68.

${ }^{6}$ Robert L. Sutherland and Maxwell Woodward, Introductory Sociology (Philadelphia: Lippincott, 1948), 368.

${ }^{7}$ Sean Wilentz, "Rise of the Working Class," (M.A. Thesis, Northern Illinois University, 1990).
} 
a cultural construction defined by those who are active members in it, so while class can be define on paper the real importance is how the community acted in regards to class. ${ }^{8}$ Class formation involved the larger community that "caused classes to take shape" in relation to each other. ${ }^{9}$ One thing that all classes held in common was a need for fellowship. In an age of demographic expansion the lodge was seen in the community as an outgrowth of the industrial culture were men of different classes could seek this fellowship. The question remains then, in this period of societal flux, how much did social class influence Masonic membership?

In this study, the main variable used to determine social class in the Copper Country is occupation. One member, Paul P. D. Roehm, who worked as a laborer in 1920, joined the lodge in 1918. He followed family tradition: his father Paul P. Roehm and brother Hiram H. Roehm were also Masons. From Erik Williamsen the miner, to Arthur C. Jones, Agent of the Mineral Range Railroad, the men of the lodge came from multiple backgrounds and covered many aspects of the society. ${ }^{10}$ It is necessary to break the occupations down into four or five groupings to allow a comparison between the men's social rank and to see if patterns of membership, such as Lodge officers, were affected by economic class. The Masons came from upwards of forty occupations in 1900 and even more in 1920; the sheer diversity of jobs necessitated a simple division into five economic classes.

\footnotetext{
${ }^{8}$ Elizabeth M. Scott, Those of Little Note (Tucson, AZ: University of Arizona Press, 1994), 97.

${ }^{9}$ Stuart Blumin, The Emergence of the Middle Class: Social Experience in the American City, 1760-1900 (New York: Cambridge UP, 1989), 258.

10 “Annual Return Calumet Lodge 271," 1920.
} 


\section{Classes within Calumet}

The "fundamental economic class structure" of Calumet included the poor class, a working class of unskilled and semiskilled workers such as miners and trammers, an “artisan [middle] class of skilled workers," a professional class of white collar workers including doctors and lawyers in the upper middle, and then the elite of society - the "mining capitalists, managers." Within this sectioned division of classes there are some occupations that defy a niche, including the mine captains. Above mine captains were the head mine captain, "part manager, part geologist, and part mining engineer" that will be categorized as middle class . ${ }^{12}$ Each mine captain "orchestrated the mine's entire production" and produced the metal that was cast into profits at the smelter. ${ }^{13}$ Given their level of autonomy, practical working knowledge of the mines, and the authority invested in these individuals by the company they had more in common with the middle than the lower class. Even if they worked in the same location as miners, they were masters of their craft.

In 1900 the members worked in jobs as members listed as a 'miner': John Berryman, Richard Edwards, and John S. Morrison, to Lachlan McNab as watchman, and Charles W. Niles who worked as a physician in the Calumet and Hecla Hospital. Their multiple occupations were divided into four classes; working class occupations

\footnotetext{
${ }^{11}$ Paula Petrik, "No step backward: Women and family on the Rocky Mountain mining frontier, Helena, Montana, 1865-1900," Montana Historical Society, (1987), quoted in Mary Jackman, "The Subjective Meaning of Social Class Identification in the United States," The Public Opinion Quarterly, 43, no. 4 (Winter 1979): 445.

${ }^{12}$ Lankton, Cradle to Grave, 59.

${ }^{13}$ Ibid, 60 .
} 
consisted of miners, supply clerks, bookkeepers, and draftsmen. The middle class had men working as instructor at the manual training school, Calumet's postmaster, mine captains, plumbers, and other skilled trades. Upper middle class men had occupations ranging from physician, and lawyers, to James D. Ramsay - the superintendent of motive power for Houghton and Torch Lake Railroad. The elite group was more limited and included Calumet and Hecla's superintendent - James McNaughton as well as Robert B. Wetzel - the chief pharmacist of the Calumet and Hecla Hospital. Lodge 271, however, did not have any members who could have been classified in the poor class. Due to the cost of membership this is not surprising. These occupations were divided based largely on their relationship to the means of production. Jobs that involved more manual labor ranked lower on the economic scale than jobs that involved a skilled trade or higher education. Following the divisions used by both Jackman and Wright, occupations were used to define a man's economic class. Occupations such as the overseer of Calumet and Hecla's blacksmith shop in 1900 - Charles Rupprecht - ranked among the middle class because of their moderate level of authority within the organization. Clerks, miners, and bookkeepers, while white and blue collar occupations, were both working class because of their wage-labor occupations involving nonsupervisory positions. However, while ethnicity within the lodge was recorded through the census records, a corresponding relationship between occupations, class, and ethnicity was not included for this study but the percent of members of different ethnic groups was recorded in the data. 


\section{Chapter 5: "Brethren Upon the Same Level:" Class Membership}

\section{Previous Research}

Like other fraternal orders, the Masons “possessed a strong appeal for American men." ${ }^{1}$ Scholars (such as Guillermo De los Reyes and Antonio Lara in Civil Society and Volunteerism: Lodges in Mining Communities, and Lynn Dumenil in Freemasonry and American Culture) have examined class membership within lodges. ${ }^{2}$ According to Masonic rhetoric "economic, political, and religious differences became unimportant," within the lodge as the brethren were equal. ${ }^{3}$ For Dumenil, even though "Masons claimed their order was composed of all classes...it was predominantly middle class."4 She noted that "the bulk of the membership was drawn from the low-level white-collar group" such as clerks and salesmen. ${ }^{5}$ This is taken from her study of Live Oak Lodge in Oakland, CA from 1880 to 1900. Dumenil's study provided a good perspective on membership for an urban lodge. In general the Masons had essentially a "native, middle-class Protestant nature."6 John Cumbler, in Working-Class Community in Industrial America, thought of lodges as a "working-class community institutions, both formal and informal [which] acted to maintain strong class solidarity as well as

\footnotetext{
${ }^{1}$ Clawson, "Fraternal Orders and Class Formation," 672.

${ }^{2}$ Guillermo De Los Reyes and Antonio Lara, "Civil Society and Volunteerism: Lodges in Mining Communities," Annals of the American Academy of Political and Social Science, vol. 565 (September 1999): 220.

${ }^{3}$ Dumenil, Freemasonry and American Culture, 103.

${ }^{4}$ Ibid, 12.

${ }_{6}^{5}$ Ibid, 12.

${ }^{6}$ Ibid, $12-14$.
} 
contribute to collective action. ${ }^{, 7}$ In some mining towns, in Montana and California for instance, "the first voluntary association organized" was a Masonic Lodge. ${ }^{8}$ Like Calumet's Lodge 271, Dumenil noted Masons had a higher percentage of “clerks, salesmen, accountants...retail merchants" and a lesser proportion of "doctors, lawyers and other professionals." This breakdown was echoed in Lodge 271 through the member's occupations listed in the Polk Directory and the U.S. Census. The Masons drew from Calumet's population, but it was not a representative sample of the entire population. Census data is not available to determine how many occupations existed in the vicinity of Calumet, and how representative Lodge 271 was.

Historian William Moore, in Masonic Temples, noted that Masonry was "composed almost exclusively of middle-class men of European decent." ${ }^{\text {"9 }}$ He drew this from New York Masonic membership, which in 1929 composed 10\% of the entire American Masonic organization. As such, with the wide variation in urban, rural, agricultural and industrial workers provides a fair cross-study of the overall fraternal group. Among the members he studied were leading citizens in the towns. In addition to this there were men who aspired to achieve social status and saw the lodge as a means to that end. To give an idea as to their scope, in 1900 the Masons with their 11,600 local lodges initiated 50,000 new brothers. ${ }^{10}$

Mary Ann Clawson argued that class relations within the lodge were more

\footnotetext{
${ }^{7}$ John Cumbler, Working-Class community in Industrial America: Work, Leisure, and Struggle in Two Industrial Cities-1800-1930 (Westport, Conn: Greenwood Press, 1979) quoted in Clawson, "Fraternal Orders and Class Formation," 673.

${ }^{8}$ De Los Reyes, "Civil Society and Volunteerism," 220.

${ }^{9}$ Moore, Masonic Temples, xvii.

${ }^{10}$ Mark A. Tabbert, American Freemasons (New York: NYU Press, 2006), 124.
} 
complex, that they were not the "working class community institutions" that Cumbler described. ${ }^{11}$ Clawson saw the Masons as the "accepted elite of the fraternal world," which they reinforced through their "venerable traditions and greater selectivity" than other groups. ${ }^{12}$ Historian Guillermo De Los Reyes reinforced this through a study of mining communities in California; he concluded "Freemasonry was not a working-class phenomenon."13 With Clawson "a focus on the Masons as the representative group [of fraternities] may lead to an underestimation of working-class participation in the movement." ${ }^{14}$ In a way, Clawson preferred not to study the Masons because of the perceived higher percentage of members that belonged to elite groups. Her analysis did not take into account the extent of Lodge member variations at the local level. Within Lodge 271 the horizontal networks created within the lodge "provided a contrast to the hierarchical social relations of the workplace and civil society." 15

\section{Division Between Occupations}

Between the five economic classes - poor, working, middle, upper middle and elite or professionals into multiple classes- the question presented itself on how to divide occupations between them. Which occupations belong in which economic class? Class beyond occupation and income, is also reflected in the "attitudes and values" of the group. ${ }^{16}$ In her article, "The Subjective Meaning of Social Class Identification in the United States," Mary Jackman tackled the issue of dividing different occupations into

\footnotetext{
${ }^{11}$ Clawson, "Fraternal Orders and Class Formation," 673.

${ }^{12}$ De Los Reyes, "Civil Society and Volunteerism," 220.

${ }^{13}$ Clawson, "Fraternal Orders and Class Formation," 679.

${ }^{14}$ Ibid, 679.

${ }^{15}$ Clawson, Constructing Brotherhood, 94.

${ }^{16}$ Loren Baritz, The Good Life: The Meaning of Success for the American Middle Class (New York: Perennial Library, 1989), 105.
} 
classes. Because "occupation has traditionally been regarded as a key element of socioeconomic status" she looked at how Americans perceived class in relation to occupation. ${ }^{17}$ In her survey of Americans she used occupation as the main division between classes. Membership within a class was also defined by lifestyle, beliefs, and feelings "in terms of shared objective characteristics." ${ }^{18}$ A comparison by occupation provides the most reliable insight into class divisions. According to economist Douglas Eicher, in Occupation and Class Consciousness in America, occupation was one of the most important determinants of class besides education. ${ }^{19}$ As early as 1897 , William C. Hunt of the U.S. Bureau of Census "grouped occupations into four hierarchical categories" as part of an occupational based scheme for economic class ranking. ${ }^{20}$ Eicher also concluded in his study that there is a "relationship between class and occupation," even though classes are heterogeneous in their membership. A class with heterogeneous membership was a class that drew from multiple occupations. E.P. Thompson noted that class consciousness is a "consciousness of the identity of interests between working men of the most diverse occupations and levels of attainment." ${ }^{21}$

In 1940s America class was also seen as a set of values, enhanced or formed by an economic standing. ${ }^{22}$ Some occupations that had high earnings may have had a relatively low social class due to social connotations. This is in contrast with the

\footnotetext{
${ }^{17}$ Jackman, "The Subjective Meaning of Social Class," 444.

${ }^{18}$ Ibid, 445 .

${ }^{19}$ Douglas M. Eichar, Occupation and Class Consciousness in America (Santa Barbara,CA: Greenwood Press, 1989), 84.

${ }^{20}$ Eicher, Occupation and Class Consciousness, 10.

${ }^{21}$ E.P. Thompson, The making of the English working class (New York: Vintage Books, 1966), 807.

${ }^{22}$ Baritz, The Good Life, 106.
} 
Weberian approach to class that is determined "solely [by] an economic category." 23 Class also included a "social affiliation of members, shared lifestyle and beliefs." ${ }^{24}$ Max Weber, the sociologist and economist, in Occupation and Class Consciousness in America, noted that classes "merely represent possible bases for communal action;" they were not usually routes through which communal identities were formed. ${ }^{25}$ Individuals of similar economic standing likely formed these identities. It is important to note that while categories and divisions between economic sectors of the American public are used to define class, the notion itself is subjective based on how the general public defines class membership. ${ }^{26}$ Thompson noted that class-consciousness is a "consciousness of the identity of interests between working men of the most diverse occupations and levels of attainment." ${ }^{, 27}$ As such, myriad occupations can find common ground within one class, from working to upper class.

Erik Olin Wright reinforced this division of the classes that Jackman put forth to some extent in his article, "Class and Occupation." Even when classes are not defined by occupations, he saw classes as determined in a large part by occupations. He divided the population into seven categories through the Institute of Social Research Survey of Working Conditions conducted in 1969 with a national random sample of 1,533 adults. ${ }^{28}$ The survey included questions that allowed a "rough operationalization of classes," with which people identify. His studies largely aligned with Jackman, having a

\footnotetext{
23 Jackman, "The Subjective Meaning of Social Class," 445.

${ }^{24}$ Ibid, 445.

${ }^{25}$ Max Webber as quoted in Eichar, Occupation and Class Consciousness, 4.

${ }^{26}$ Jackman, "The Subjective Meaning of Social Class," 444.

${ }^{27}$ E.P. Thompson, The making of the English working class, 807.

${ }^{28}$ Erik Olin Wright, "Class and Occupation," Theory and Society 9:1 (January 1980), 184. In his 1980 study he revised it to 12 categories.
} 
bourgeoisie, top managers and middle managers, bottom managers and foreman and the proletariat. These groups align with the working, middle, upper middle and upper classes expressed by Jackman. Also "71\% of all unskilled laborers" are in the working class with Wright, with $75 \%$ of the factory workers listed as working class under Jackman. ${ }^{29}$ There then seems to be an agreement on social class divisions based on occupation between the two, adding further weight to the divisions used by Jackman and adopted for this study, especially between the association between the working class and manual occupations.

Table 5.1

Social Classes Assigned by Occupation

\begin{tabular}{|c|c|c|c|c|c|c|c|}
\hline Occupations & Poor & Working & Middle & $\begin{array}{c}\text { Upper } \\
\text { Middle }\end{array}$ & Upper & Don't Know & Base N \\
\hline Migrant farm workers & $73.3 \%$ & $21.7 \%$ & $2.2 \%$ & $0.5 \%$ & $0.5 \%$ & $1.7 \%$ & 1,846 \\
\hline Janitors & 25.2 & 66.6 & 6.1 & 0.5 & 0.2 & 1.4 & 1,840 \\
\hline $\begin{array}{c}\text { Assembly-line workers } \\
\text { and laborers }\end{array}$ & 5.0 & 75.1 & 16.0 & 1.7 & 0.7 & 1.6 & 1,862 \\
\hline $\begin{array}{c}\text { Workers in offices and } \\
\text { stores }\end{array}$ & 1.5 & 59.9 & 33.4 & 3.4 & 0.8 & 1.0 & 1,843 \\
\hline $\begin{array}{c}\text { Plumbers and } \\
\text { carpenters }\end{array}$ & 1.1 & 43.9 & 40.0 & 11.7 & 1.9 & 1.3 & 1,853 \\
\hline $\begin{array}{c}\text { Foremen in factories } \\
\text { Schoolteachers }\end{array}$ & 1.4 & 18.7 & 59.7 & 17.4 & 2.5 & 1.2 & 1,858 \\
\hline Small businessmen & 1.7 & 17.6 & 60.5 & 17.7 & 1.2 & 1.3 & 1,859 \\
\hline $\begin{array}{c}\text { Supervisors in offices } \\
\text { and stores }\end{array}$ & 0.1 & 16.7 & 56.2 & 22.5 & 3.2 & 1.3 & 1,853 \\
\hline $\begin{array}{c}\text { Business executives } \\
\text { and managers }\end{array}$ & 0.1 & 3.0 & 13.8 & 55.8 & 25.7 & 1.6 & 1,861 \\
\hline Doctors and lawyers & 0.0 & 1.8 & 3.9 & 35.6 & 57.1 & 1.7 & 1,866 \\
\hline $\begin{array}{c}\text { Corporation directors } \\
\text { and presidents }\end{array}$ & 0.4 & 1.3 & 3.0 & 21.5 & 71.8 & 1.9 & 1,852 \\
\hline
\end{tabular}

In 1975 the Survey Research Center conducted a "national probability survey of adults" over eighteen years old living in the contiguous United States. Through a series of questions the Center asked respondents "which of these classes - poor, working,

${ }^{29}$ Wright, "Class and Occupation,” 187, Jackman, "The Subjective Meaning of Social Class," 449. 
middle, upper middle, and upper class" - do you associate yourselves with and which class do you associate occupations with. ${ }^{30}$ The study received 1,914 responses, and all but $3.3 \%$ of respondents were able to identify with one of the five classes. In this study 7.6 percent identified with the poor, 36.6 percent with the working class, 43.3 percent with the middle class, 8.2 percent with the upper middle, and 1.0 percent with the upper class. This study asked the respondents how strongly they felt about their class identification. Eighty percent felt "at least somewhat strongly" about their class. ${ }^{31}$ The respondents were next asked to divide twelve occupations into the five classes; an agreement was reached about the class locations of the occupations. The twelve occupations in the study had to be broad enough to be easily recognized by the crosssection of Americans involved in the survey, and most of the respondents "completed the occupation-class sort board with little or no hesitation." ${ }^{, 32}$ This is compared to the over 28,000 occupations recorded in the 1970 U.S. Census. Basic agreement existed then on how occupations were associated with one of the five economic classes based on the survey results. As seen in the Table 5.1, from Jackman's study, moving from the top to the bottom of the occupations the class placement shifts from poor to upper class with a slight percent of respondents who were unsure. ${ }^{33}$

One pattern that Jackman noticed is that jobs in the middle - skilled-blue collar work and factory foreman, as well as factory workers to some extent - had an almost even distribution between the working and middle class. This is because those job titles had to be vague, and encompassed more internal variance in "prestige, job authority,

\footnotetext{
${ }^{30}$ Jackman, "The Subjective Meaning of Social Class," 446.

${ }^{31}$ Ibid, 447.

${ }^{32}$ Jackman, "The Subjective Meaning of Social Class," 448.

${ }^{33}$ Jackman, "The Subjective Meaning of Social Class," 449.
} 
educational attainment, and income" than workers at either the top or bottom of the list. ${ }^{34}$ Relatively unskilled, low-authority, blue-collar workers such as miners or trammers, which were "organized in group settings," seem to fit in the working class based on the nature of their work. ${ }^{35}$ The point is how people perceived class and social standing on the streets of Calumet, with occupation being the main determinate of economic class.

When people in similar positions become akin in thinking and lifestyle they tend to form social classes. ${ }^{36}$ As Americans moved into the middle class they sought to express a cultural affinity of their social ranking as a means of class attainment. Was one of the main ways through which individuals expressed class in the Copper Country by who joined the Free and Accepted Masons? ${ }^{37}$ As an act of class attainment, men from multiple classes joined the lodge as evidenced in the numerous small business owners, clerks, and middle class occupations that choose membership in Lodge 271. The multiple occupations in the 1900, 1908, and 1917 Polk's Directory were divided among classes as outlined in the 1975 Survey Research Center of the Institute for Social Research. Using the available data, it is possible to determine if Calumet's Lodge 271 had a significant working class membership. While relying on the 1975 survey for this study that is not to say that class identity was not studied previous to the sociological studies of the 1960s and 1970s. Author Mark Twain, in The Gilded Age, offered a commentary on the role of class in America during the second half of the $19^{\text {th }}$ century.

\footnotetext{
34 Jackman, "The Subjective Meaning of Social Class," 450.

35 Ibid, 450.

${ }^{36}$ Dennis L. Gilbert, The American Class Structure (Newbury Park,CA: Pine Forge Press, 1998), x.

${ }^{37}$ Ethnic lodges include the Italian-American Mutual Aid Society and the St. Stanislaus Lodge of the Polish Roman Catholic Union of America.
} 
He writes of Squire Hopkins whose neighbors in Obedstown of East Tennessee “dressed in homespun jeans," all "wore one suspender and sometimes two" who composed the country working class seeking a living off the land. ${ }^{38}$ Also he made note of Senator Abner Dilworthy who occupied himself with "guiding the destinies of the nation." ${ }^{39}$ At the top of society were the great men, the wealthy elite, and the economic system that favored them. The men that joined the Masons were likely aware of the class divisions within society by using their increased economic mobility as a means of social attainment.

\section{In Relation to Each Other}

Each of the five classes had a set of characteristics that helped in assigning a class identity to the different occupations. One aspect is the validity through which economic classes gained importance through their relationships to each other. By sorting twelve occupations between five classes the respondents were forced to see their contextual relevance. ${ }^{40}$ The poor class was noted by marginal occupations with an irregular employment schedule. The working class included all "wage-laborers regardless of their function within the production process" mainly including those involved with productive "manual, non-supervisory labor." that "class experience is largely determined by the productive relations into which men are born." ${ }^{, 42}$ The working class has also been defined as someone whose labor directly

\footnotetext{
${ }^{38}$ Mark Twain, The Guided Age Vol. I, vol. 10 of Mark Twain's Works (New York: Harper \& Brothers, 1901), 14.

${ }^{39}$ Mark Twain, The Guided Age Vol. I, 225.

${ }^{40}$ Wright, "Class and Occupation," 177.

${ }^{41}$ Wright, "Class and Occupation," 179.

42 Thompson, The making of the English working class, 9.
} 
produces surplus value, along a neo-Marxist view. The middle class was generally white-collar, with moderate job authority associated with low-level professionals. Between working class and middle class there was a divide between skilled blue-collar work like plumbers and blacksmiths, who due to their higher level of responsibility and autonomy were more likely to be associate themselves with the middle class. The upper middle class was generally associated with upper level positions in business, plus doctors, and lawyers. The upper class consisted of the social elite. ${ }^{43}$ This breakdown matched the demographic classification used in the United Kingdom, as seen in their NRS social grades. ${ }^{44}$ The social grades assign a social class based mainly on the occupation of the head of the household from higher managerial to pensioners. Through Jackman and Wright, as well as the social grades, a clear relationship between occupation and class has been outlined for the purpose of this study.

\section{Lodge 271}

Lodge 271 provided an understanding of class relationships among members within the lodge setting. Of the four members listed as having joined Lodge 271 in 1900, there was an engineer, a mine captain, the Wolverine Copper Mining Company's chief clerk, and a driver for D.A. Holland. The membership for the lodge stood at 159 members in 1900, with Table 5.2 providing a breakdown of membership into the five classes discussed above and defined by Jackman. Table 5.2 is derived fro the

\footnotetext{
${ }^{43}$ Jackman, "The Subjective Meaning of Social Class," 455.

${ }^{44}$ Occupation Groupings: A Job Dictionary, $6^{\text {th }}$ ed. http://www.mrs.org.uk/publications/downloads/occgroups6.pdf
} 
occupations of members listed in the 1902 and 1918 Polk Directories and the U.S. Census.

When compared to the occupation distribution in Table 5.3 it becomes clear that in the Masonic lodge the middle class had a high representation. Table 5.2 lists a local division of economic class in Lodge 271, while table 5.3 has the occupational division of economic classes at a national scale in 1900 and 1920. Through this Lodge 271can be seen in comparison to national trends in class and a occupational breakdown. The clerical, sales, operatives, and nonfarm laborers correspond with the working class. Those noted as 'craft, managers and administrators, and professional and technical' that correspond to the middle, upper middle, and upper classes are disproportionally represented. The services sector in Table 5.3 accounted for about eight to nine percent of the United States population in 1900 and 1920 and sat at the low end of the social spectrum. This would be in the poor class, which counted no members in Lodge 271. In 1900 and 1920, 37.5\% and 27\% of Americans repectively were employed in agriculture, while both the 1900 and 1920 Annual Report for Lodge 271 listed no members from that category of employment. ${ }^{45}$ This occupational structure helped to illustrate the point that the upper middle, and upper classes congregated in the lodge

\section{Table 5.2}

Masonic Membership in 1900 and 1920 for Lodge 271

With Members Divided by Social Class

\begin{tabular}{|c|c|c|c|c|c|c|}
\hline Class & Poor & Working & Middle & U. Middle & Upper & N/A \\
\hline Number in 1900 & 0 & 45 & 44 & 45 & 3 & 22 \\
\hline Percent in 1900 & $0 \%$ & $28 \%$ & $27 \%$ & $28 \%$ & $2 \%$ & $14 \%$ \\
\hline Number in 1920 & 0 & 66 & 62 & 58 & 8 & 25 \\
\hline
\end{tabular}

${ }^{45}$ Eichar, Occupation and Class Consciousness, 46. 
hall and it also had a significant middle and working class membership. The fact they were seen in higher numbers within the lodge than society in general, showing that that the middle class had a significant representation within Lodge 271. As anthropologist Viktor Turner noted, communitas, or the spirit of community, tended to be inclusive rather than exclusive. ${ }^{46}$ Masonic communitas thus allowed men who expressed an interest in joining the lodge to do so - assuming they passed the ballot. While he was not studying Masons, his studies on group organizations add insight to Masonic membership.

It's important to note that the lodge membership was not representative of the larger community of which it was a component part. With about thirty percent of the membership coming from the working class, it was underrepresented within the Lodge. Also with roughly thirty percent of the membership, the upper middle class was overrepresented. However Calumet's Lodge had a substantial faction of working class members, which nearly equaled the middle and upper middle class. It is interesting that the divisions between classes remained nearly constant over the study period. This allowed the working class members to have a substantial voice within Lodge activities. An important distinction when talking about white-collar and blue-collar membership is that membership in one of the two classes does not imply membership in a social class. Numerous clerks, bookkeepers, and miners all fit within the working class and may have had values more in line with each other. ${ }^{47}$ When comparing a low-level clerical

\footnotetext{
${ }^{46}$ Viktor Turner, From Ritual to Theatre: The Human Seriousness of Play (New York: Performing Arts Publications, 1982), 51.

${ }^{47}$ As opposed to two distinct social classes.
} 
worker to an upper-level manager, even though both the clerical worker and manger could be counted as 'white-collar,' they may have belonged to distinctly different social classes. There is a tendency to treat this division "as a fundamental division between classes rather than an internal division within the working class. ${ }^{, 48}$ These numbers contravene the data found by Roy Rosenweig, Lynn Dumenil and John Gilkson who found through the lodges they examined that about "75 percent of the members...were white-collar workers" on the national level. ${ }^{49}$ While Clawson argued that being whitecollar denotes a social class separate and perhaps above a blue-collar employee, that most likely was not how the social stratification was practiced in the community or perhaps within the lodge setting at Calumet. Clawson focused on groups other than the Masons because they would not allow a means to "understand class character [in a] fraternal [body]." 50

Table 5.3

Occupational Distribution in the United States in 1900 and 1920

\begin{tabular}{|c|c|c|}
\hline Occupation & 1900 & 1920 \\
\hline White Collar & $17.6 \%$ & $24.9 \%$ \\
\hline Professional and Technical & 4.3 & 5.4 \\
\hline Managers and Administration & 5.8 & 6.6 \\
\hline Clerical & 3.0 & 8.0 \\
\hline Sales & 4.5 & 4.9 \\
\hline Blue Collar & 35.8 & 40.2 \\
\hline Craft & 10.5 & 13.0 \\
\hline Operatives & 12.8 & 15.6 \\
\hline Nonfarm Laborers & 12.5 & 11.6 \\
\hline Services & 9.0 & 7.8 \\
\hline Farm Workers & 37.5 & 27.0 \\
\hline Total & $100 \%$ & $100 \%$ \\
\hline
\end{tabular}

${ }^{48}$ Wright, "Class and Occupation," 192.

${ }^{49}$ Clawson, Constructing Brotherhood, 94.

${ }^{50}$ Ibid, 96. 
In Calumet, however the Lodge provided the insight needed to understand economic class relations in a fraternal context.

\section{Masonic Portraits}

To illustrate the variety of men who belonged to Lodge 271 a portrait will be drawn of Willard J. Smith, Albert R. Tucker, and Thomas H. Soddy. This will give a more complete illustration of what type of men called themselves Masons in 1910. All three of the members were of the upper middle class and do not reflect the middle class lodge members. Willard Smith was described as a "wake-awake, brainy and enterprising young man" from Mohawk, Michigan. His father and grandfather both worked for the copper mines so it was only fitting that after graduating from the Michigan School of Mines in 1899 he found employment with the Wolverine and Mohawk mines. In 1903 he was promoted to the superintendancy of the mines. Like many of his contemporaries Mr. Smith was "prominent in fraternal circles," he belonged to four Masonic bodies as well as the Elks. ${ }^{51}$

Thomas Soddy also belonged to the Shriners, Royal Arch Masons, Knights Templars and Masonic Lodge 271. He started work at the Pewabic Mine and took employment with the Hecla Consolidated Mining Company. His rise in that company was "continual, and step by step he [became] superintendant of the concern [the Calumet and Hecla Mining Company]" for their motive power. ${ }^{52}$ Soddy was active in

\footnotetext{
${ }^{51}$ Sawyer, A History of the Upper Peninsula and its People (Chicago: The Lewis Publishing Company, 1911), 750.

${ }^{52}$ Sawyer, A History of the Upper Peninsula, 1018.
} 
the community as well. Elected the mining company's first fire chief in 1888, another prominent individual who belonged to the lodge was Albert R. Tucker. Born in Detroit and educated at the Detroit College of Medicine and Surgery, he came to the "new village of Mohawk" in 1899. Because his activeness in his profession... he won "the confidence of the people" through his knowledge and ability. ${ }^{53}$ Like both Soddy and Smith, Tucker married a woman from the Copper Country: his wife Lila Cecilia Foley was born in Eagle Harbor. In addition to membership in Lodge 271 and other Masonic bodies Tucker was an active member in the Knights of the Modern Maccabees, Modern Woodmen of America, the Elks, the Eagles, the Sons of St. George, and numerous other Masonic bodies. ${ }^{54}$ While these three individuals shed light on who was a Mason, it provides a view favoring the privileged members of the lodge. While not featured in Sawyer's book, the working class members interacted with Tucker, Soddy, and Smith within the lodge.

While the occupations listed in the Polk Directories did not always match the Census records, the census records were used if they conflicted. The percentage of working class and middle class men who joined the lodge were part of a larger national trend in the Masons. As they joined the fraternal body they "replaced a departing older elite class of men" and turned "their attention to Freemasonry's social aspects." ${ }^{55}$ As middle class men joined, they brought their friends and family members into the lodge. While some of the older lodges may have "become more exclusive and expensive to

\footnotetext{
${ }^{53}$ Sawyer, A History of the Upper Peninsula, 1060.

${ }^{54}$ Ibid, 1061.

${ }^{55}$ Tabbert, American Freemasons, 126-127.
} 
join," this was not the case in Lodge $271 .{ }^{56}$ Through the rites of initiation, membership requirements, the shared beliefs of members, and rituals the class identity of and among the members seemed to brake down within Lodge 271. Men joined possibly as the result of the dynamic social relations in a mining town, or that men in Calumet and Laurium had a greater desire or financial ability to join the Masons. As the younger members joined the lodge at the end of the nineteenth century the social aspect of the lodge became paramount, this was expressed through the Masonic ritual and increased middle and working class membership.

\footnotetext{
${ }^{56}$ Tabbert, American Freemasons, 126-127.
} 


\section{Chapter 6: Membership Spatial Relation}

\section{Diversity}

The Calumet vicinity had a very diverse population. The people came from multiple economic and ethnic backgrounds and lived together in the mine towns. Calumet and Hecla was landlord as well as employer, and it extended considerable influence over the "social, political, as well as the economic life of" the town. ${ }^{1}$ Red Jacket was plotted on land owned by Edwin Hulbert, outside of the Calumet and Hecla industrial core. ${ }^{2}$ The Laurium Mining Company plotted, or set aside land for residential settlement twenty acres of their land in 1877 , selling off the lots for two to three hundred dollars. The fortune of both villages and the surrounding area rose and fell with the mining industry. ${ }^{3}$ Around Calumet Township the resulting population distribution was economically mixed, and while Red Jacket maintained a mostly working-class population there were also professionals that lived near their businesses. Laurium was "home to doctors, shopkeepers, bakers, barbers, laundresses, and all the other [occupations] needed to sustain a community" as well as a significant number of working class homeowners. ${ }^{4}$ The copper mines were intertwined with the community; mineshafts such as the Hecla 15 and Osceola 13 were located on the verge of the residential sections of town. While Calumet and Hecla's land penned in Red Jacket, hampering growth, Laurium grew to handle the surplus population and "experienced its

\footnotetext{
${ }^{1}$ J. Douglas Porteous, "Social Class in Atacama Company Towns," Annals of the Association of American Geographers, 64, no. 3 (September 1973): 410.

${ }^{2}$ National Register of Historic Places, Laurium Historic District, Laurium, Houghton County, Michigan, 80 .

${ }^{3}$ Ibid, 78 .

${ }^{4}$ Ibid, 78 .
} 
greatest growth in the 1890s" to 5,643 residents in 1900. The Calumet News from 1896 referred to Laurium as "our flourishing suburb" even though Laurium's population exceeded Red Jacket's 4,668. ${ }^{5}$

The area was "diverse - socially, economically, and ethnically;" Laurium was home to elite members of society such as the Roehm, Lawbaugh, and Vivian families: members in the Calumet Lodge of the Free and Accepted Masons. ${ }^{6}$ The Masons, that attracted men from multiple classes strengthened the cross-class membership of the Lodge reinforced this diversity. The members' houses in design and construction were an expression of their class. The working class of Laurium "made up a large - perhaps the largest - part of Laurium's population," with many of the workers living in Laurium due to the housing shortage in Red Jacket. With "its wide, clean streets, neat houses and well-built stores [it gave] little evidence that most of its dwellers [were] mine workers." ${ }^{7}$ In a way the population of Laurium - and Red Jacket - maintained a mixed economic setting. The "homes of the working and middle classes were not segregated from the homes of the upper class," as the attached maps of the 1900 and 1920 Masons can attest. ${ }^{8}$ Unlike other "company towns" with their "deliberate ethnic and socioeconomic segregation in housing location" it was less clear in Calumet and Laurium. ${ }^{9}$ With the "creation of separate institutions for each class" such as the YMCA and the Miscowaubik Club - a social club for Copper Country elite - the area offered members of different classes a chance to intersect within Masonic Lodge 271. Major

\footnotetext{
${ }^{5}$ National Register of Historic Places, 80 .

${ }^{6}$ Ibid, 82.

${ }^{7}$ Ibid, 86.

${ }^{8}$ Ibid, 93.

${ }^{9}$ Porteous, "Social Class in Atacama Company Towns," 411.
} 
social divisions may be part of company town life, but this was not as clearly expressed in the distribution of members but more in the architectural styles expressed in their houses. ${ }^{10}$ Membership came from all classes of the Copper Country economy; the Masons were also widely dispersed around the Calumet vicinity, drawing members from Ahmeek to Houghton. The members from Houghton and Hancock could have attended meetings at their local lodge. Its possible they joined the Calumet Lodge due to friends or family in the Lodge, or preferred Calumet to other area lodges. At a time when the Houghton County Traction Company allowed an easy commute between Copper Country villages, men could make the monthly trip to attend to their Masonic duties.

\section{Plotting Members}

One way to examine the class relationship within the lodge setting is to see if a spatial relationship existed between members of different classes. Mapping was done through the use of ESRI's ArcMap's High-Low Clustering and Average Nearest Neighbor analysis feature. First, the addresses for the group were geocoded onto the current road network in the Copper Country, matching addresses in a database to their spatial location. Geocoding began with building the reference data that were used to map the Lodge 271 members. In this case the Polk's Directory provided the address data used for 1901 and 1918 for the 1900 and 1920 membership list to see if the membership distribution changed over time. ${ }^{11}$ Their addresses were compared against the North American Geocode Service, a list of postal address for the United States,

\footnotetext{
${ }^{10}$ Porteous, "Social Class in Atacama Company Towns," 411.

${ }^{11}$ The Polk directories do not match the Census years because they were issued irregularly, in 1901 and again in 1918.
} 
giving an automatic matched percent of 68 and $72 \%$ for 1900 and 1920. Further manual matching adjusted for changes in street names or other alterations between the period of study and 2011; this brought the total matched for both periods to 81 and $82 \%$ of membership which was used for the analysis. (Figure 6.1 and Figure 6.2) The plotted members were then divided among their classes as shown in Figures 6.3 and 6.4. These figures show the divisions between the years 1900 and 1920.

With the members successfully plotted on the map one can determine spatial clustering of classes with a focus on the area around Calumet Township. The members in Ahmeek, Mohawk, Houghton, and Hancock were 2-3\% of the total population and because those members were significant spatial outliers they were discarded. For the purpose of the analysis the class membership data needed to have numerical values. This was achieved by reclassing the economic groups with working $=1$, middle $=2$, upper middle $=3$ and upper $=4$, with those of no assigned class $=0$. The High-Low Clustering measured the degree of clustering "for either high values or low values using the Getis-Ord General G statistic" for the economic classes of the Masons. ${ }^{12}$ This determined the amount to which the data were clustered, from low-clustered, random to high-clustered. The p-value in the output represents "the probability that the observed spatial pattern was created by some random process." A low value corresponds with low-clusters, a medium values indicates a random sample and a high value shows highclustering. With a p-value of 0.6685 for 1900 and 0.5664 for 1920 the patterns were both shown to be randomly distributed. As seen in Figures 6.5 and 6.6 for the clustering

\footnotetext{
12 "High-Low Clustering," ESRI, http://edndoc.esri.com/arcobjects/9.2/net/shared/geoprocessing/spatial_statistics_tools/high_low_clusterin g_getis_ord_general_g_spatial_statistics_htm.
} 
reports, both dates provide evidence of random clustering on the basis of class within the Lodge membership.

After examining the clustering of the membership the next step was to determine if the random distribution of members followed any patterns through the use of the Average Nearest Neighbor tool in ArcMap. Like the High-Low Clustering, the outliers were not included in this study. For the Average Nearest Neighbor tool, the z-value determined to what extent the data were clustered, either random or dispersed. In 1900 the $\mathrm{z}$-value was 27916.984 and for 1920 it was 12701.1652 . This is seen in Figures 6.7 and 6.8, with high z-values showing the data are significantly dispersed within the area around Calumet. The observed mean distance was 199.053 in 1900 and 67.4178 in 1920; this could be the result of the addition of seventy new members between 1900 and 1920. Either way, the members in 1920 were less dispersed than in 1900, but still significantly spatially dispersed. Given these z-scores "there is less than $1 \%$ likelihood" that the dispersed patterns could be the result of random chance. ${ }^{13}$ The result of the data analysis through the use of ArcMap reinforced the conclusion of random-dispersed membership from across multiple economic classes within the Copper Country.

\section{Masonic Households}

Another method through which the different economic classes can be understood is by analyzing at the houses of members. This included the Queen Anne styling with elaborate designs and Jacobsville sandstone foundations favored by the

\footnotetext{
13 “Average Nearest Neighbor," ESRI, http://edndoc.esri.com/arcobjects/9.2/net/shared/geoprocessing/spatial_statistics_tools/average_nearest_n eighbor_spatial_statistics_.htm
} 
upper classes. There was no spatial relationship based on where members of different economic classes lived, looking at the houses as a reflection of class might provide insight into class divisions. The examined members were: James Gribble, who worked as a mining captain for the Tamarack Mining Company and a member of the middle class; James Wilson a working class member - a bookkeeper; and William J. Galbraith, an upper middle class lawyer. Both Wilson and Galbraith lived in Laurium while Gribble lived in Calumet.

However because the buildings may have changed over time there is a chance the buildings' appearances have been altered. Figure 6.9 shows the house of James Wilson, a front-gabled two and a half story wood frame house resting on a poor rock foundation. This house reflected the Wilson's working class background in its construction and the single lot it occupied in the village. The layout of the house almost echoes its footprint in the 1917 Sanborn Map of Laurium with slight modifications over the years. As an example of a working class residence it is possible this house served as a duplex, however, according to the 1900 U.S. Census James had seven dependents, two boarders, and a servant. Boarders were a typical arrangement in the community; the boarders helped to offset the cost of owning a house and allowed the family to employ a servant. 


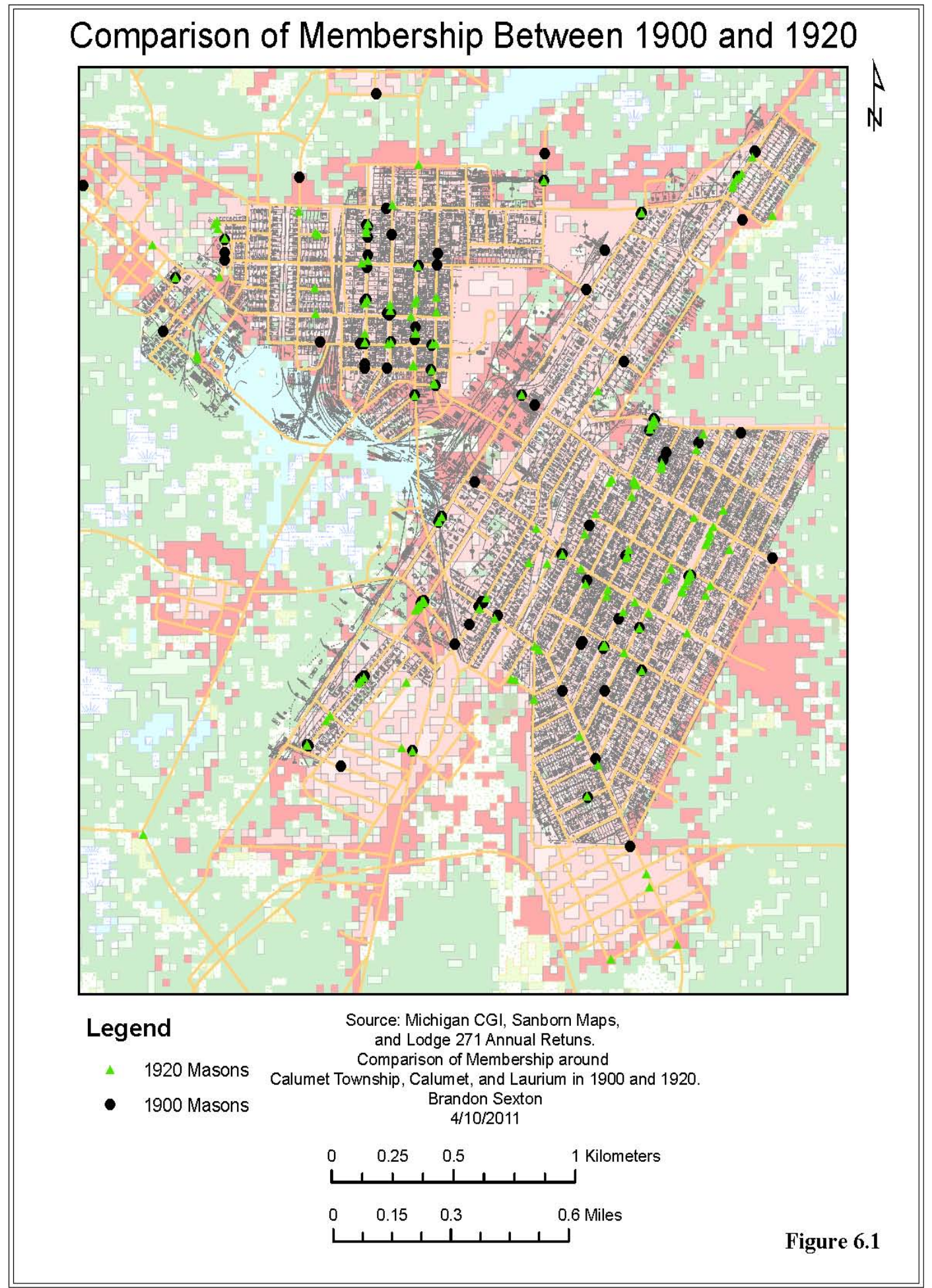

Figure 6.1: Comparison of Membership Between 1900 and 1920. 


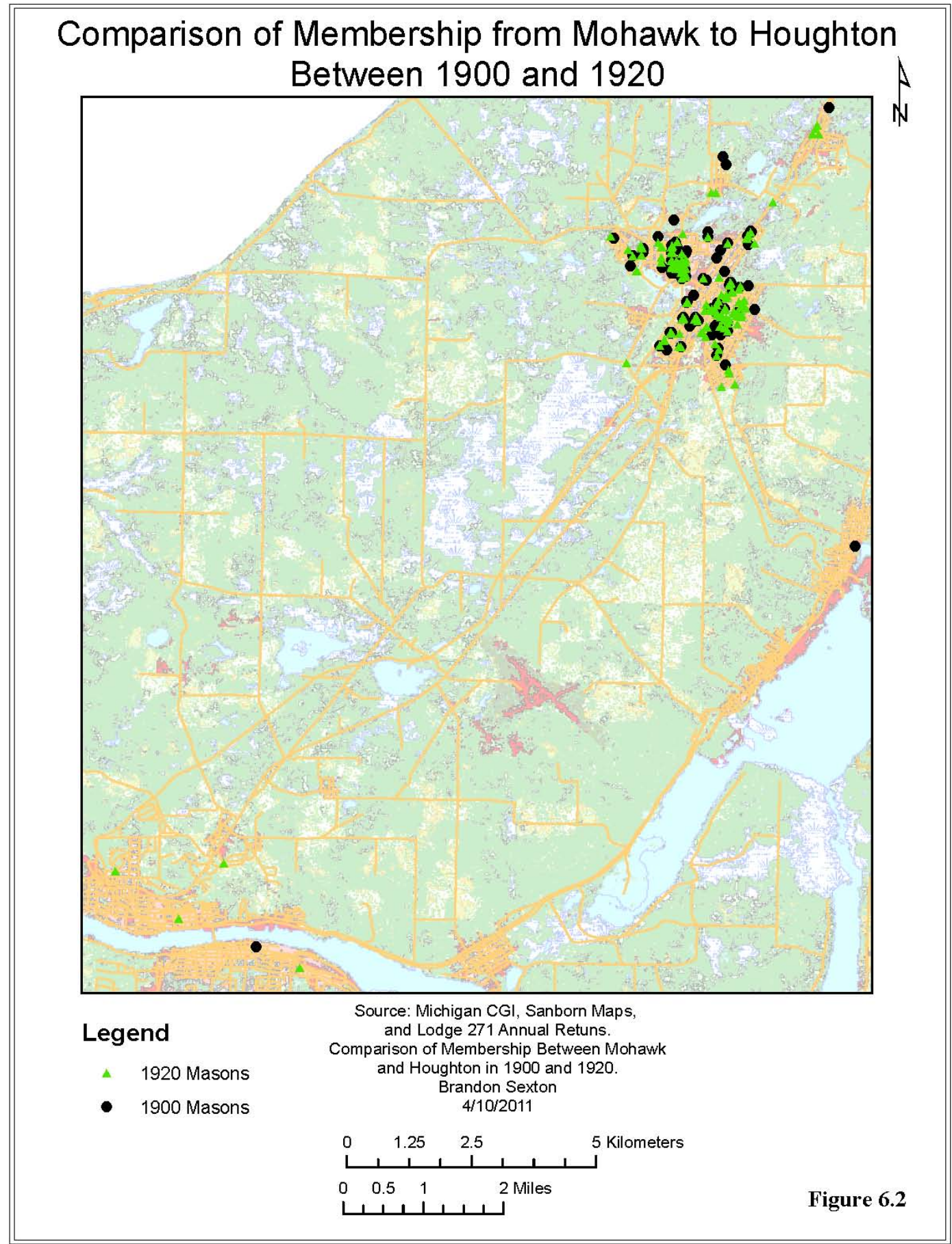

Figure 6.2: Comparison of Membership from Mohawk to Houghton Between 1900 and 1920. 


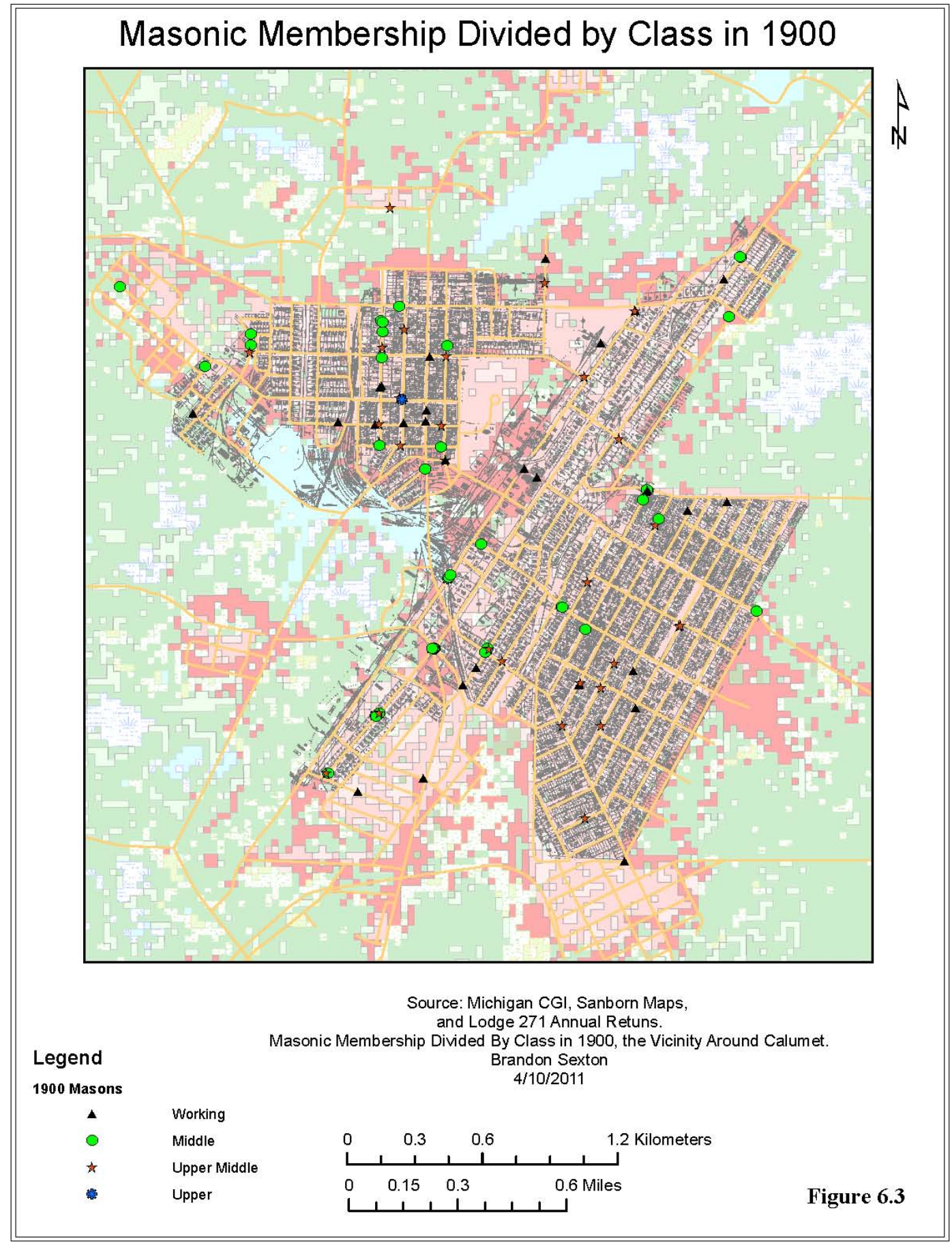

Figure 6.3: Masonic Membership Divided by Class in 1900. 


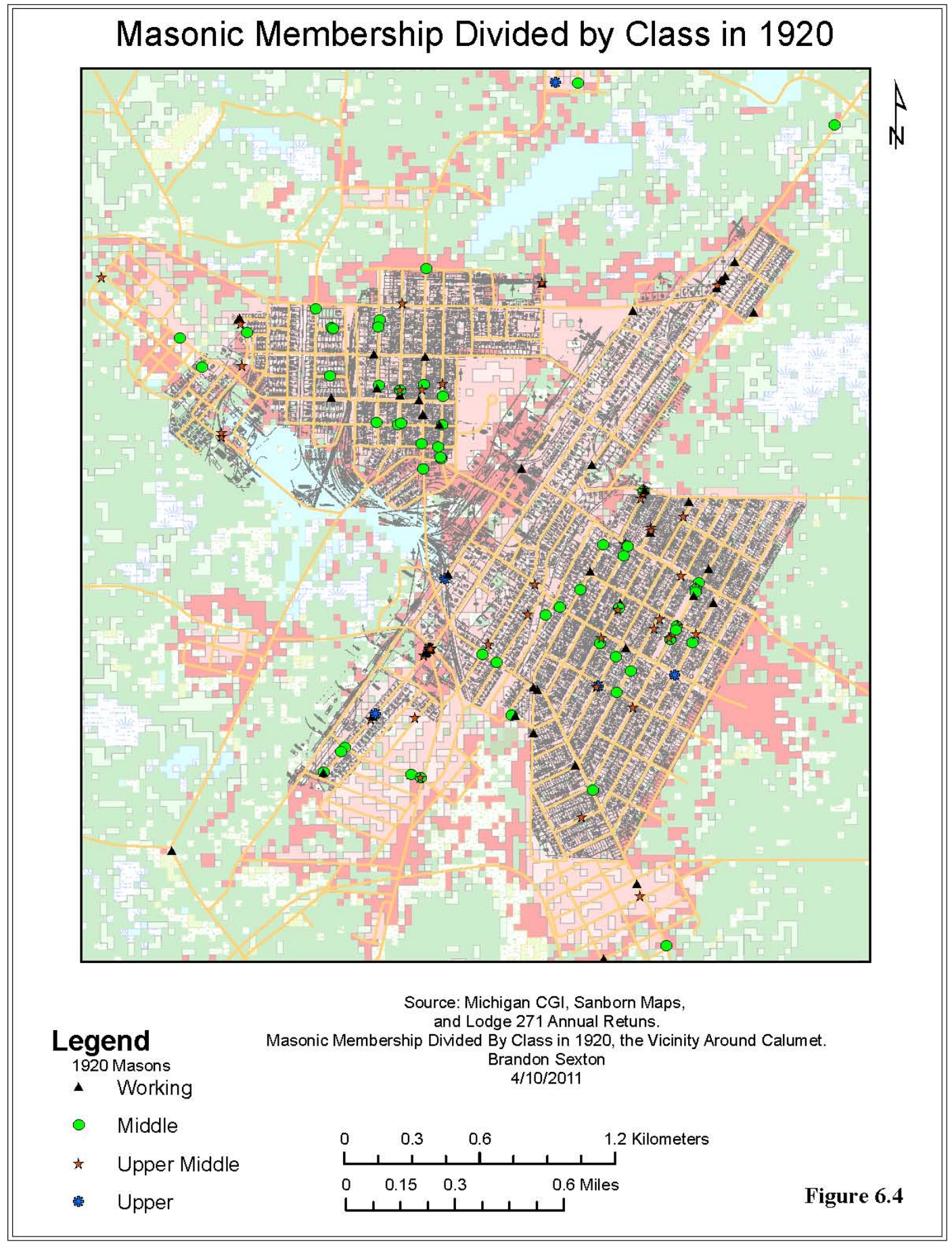

Figure 6.4: Masonic Membership Divided by Class in 1920. 


\section{High-Low Clustering Report}

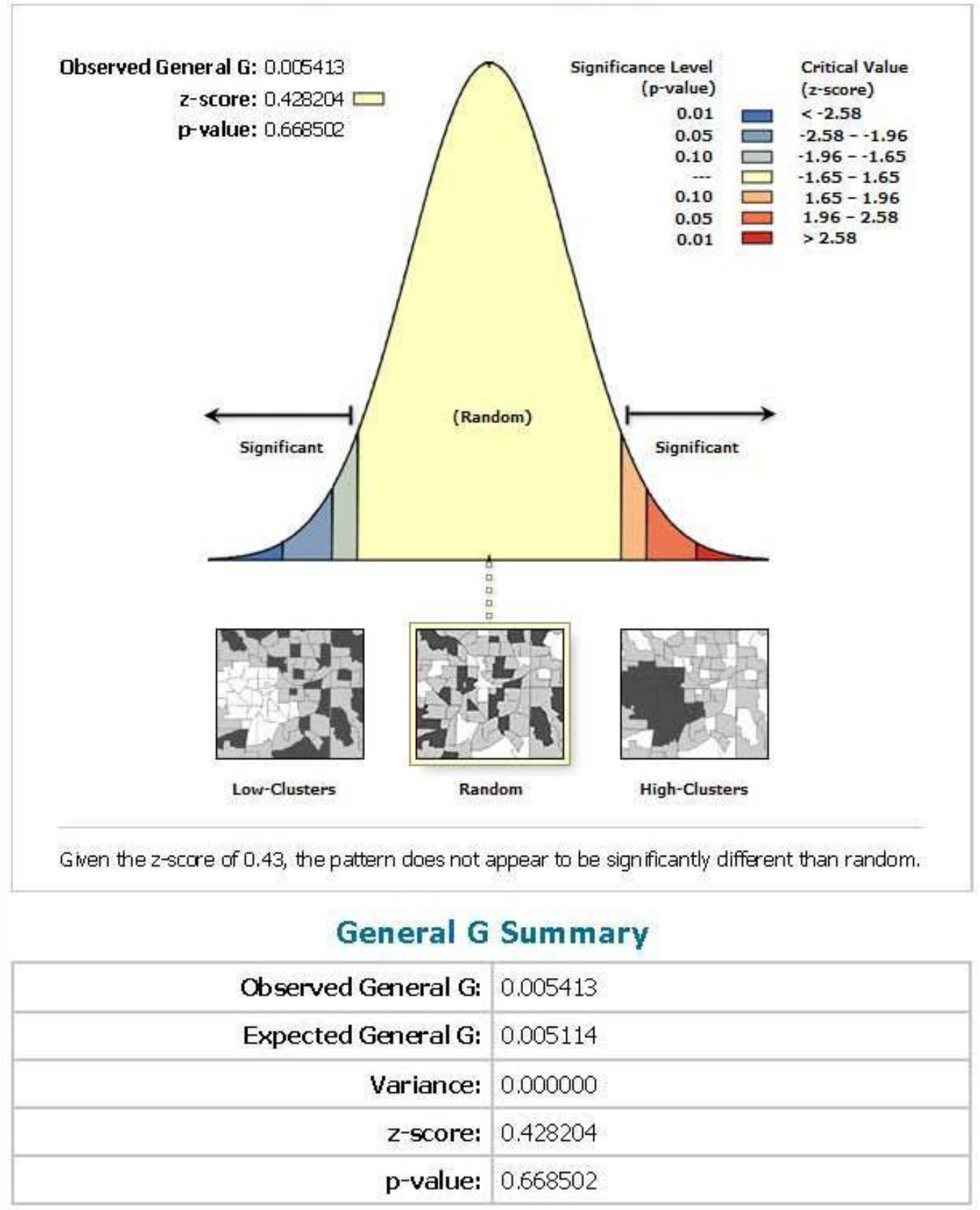

Figure 6.5: High-Low Clustering of Masonic Lodge 271 in 1900. 


\section{High-Low Clustering Report}

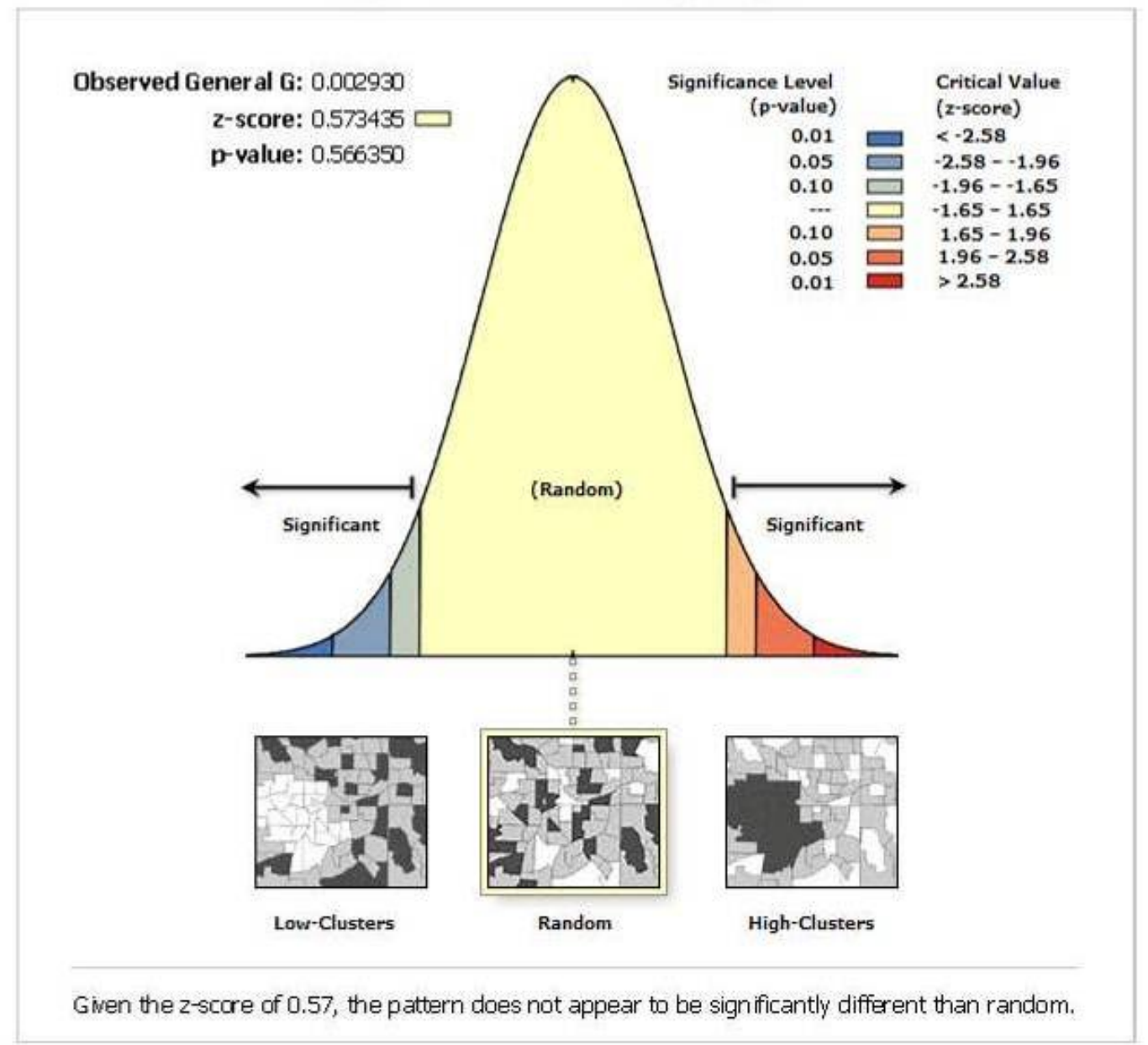

\section{General G Summary}

\begin{tabular}{|r|l|}
\hline Observed General G: & 0.002930 \\
\hline Expected General G: & 0.002749 \\
\hline Variance: & 0.000000 \\
\hline z-score: & 0.573435 \\
\hline p-value: & 0.566350 \\
\hline
\end{tabular}

Figure 6.6: High-Low Clustering of Masonic Lodge 271 in 1920. 


\section{Average Nearest Neighbor Summary}

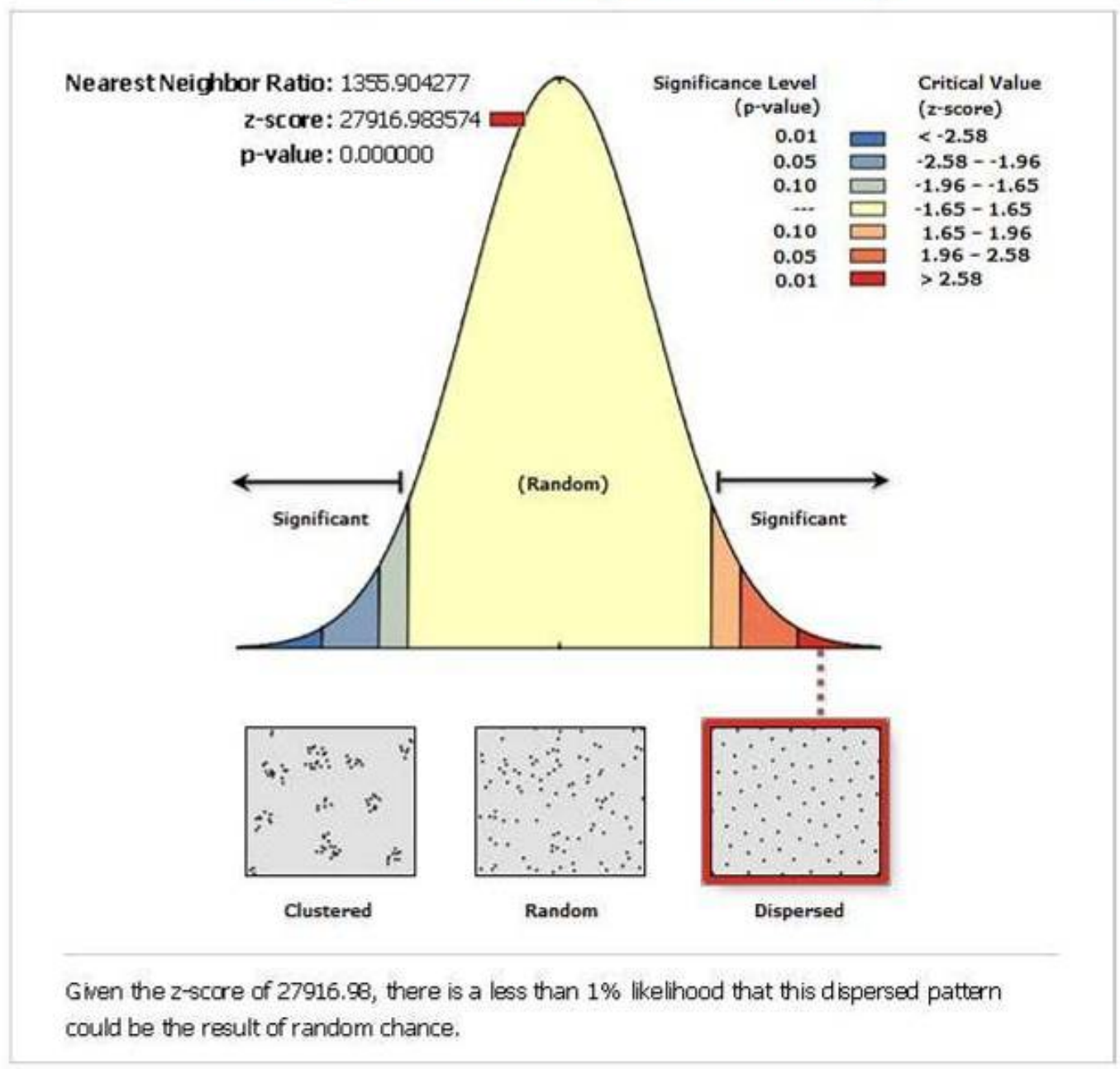

Average Nearest Neighbor Sum mary

\begin{tabular}{|r|l|}
\hline Observed Mean Distance: & 199.053602 \\
\hline Expected Mean Distance: & 0.146805 \\
\hline Nearest Neighbor Ratio: & 1355.904277 \\
\hline z-score: & 27916.983574 \\
\hline p-value: & 0.000000 \\
\hline
\end{tabular}

Figure 6.7: Average Nearest Neighbor of Masonic Lodge 271 in 1900. 


\section{Average Nearest Neighbor Summary}

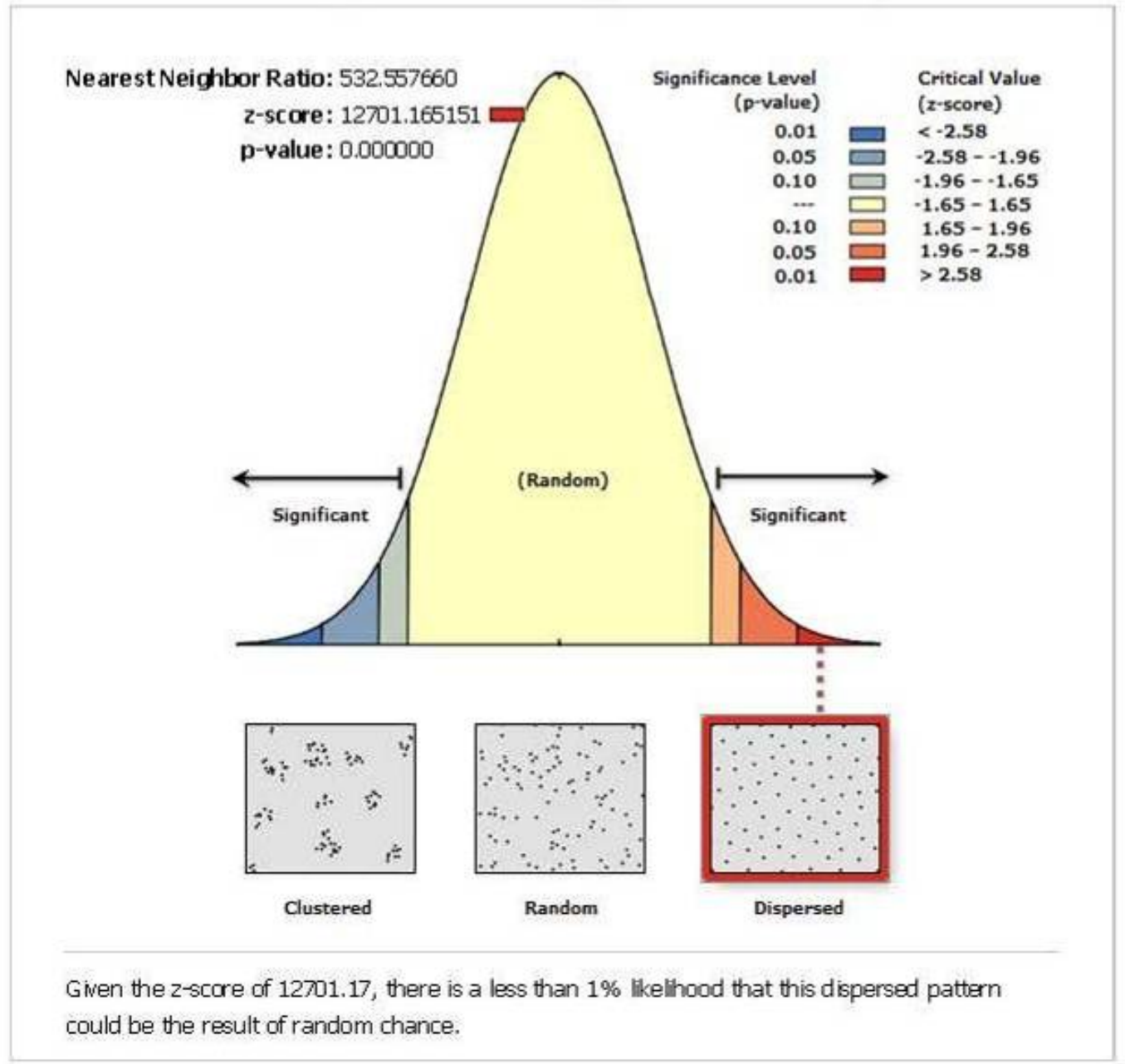

Average Nearest Neighbor Summary

\begin{tabular}{|r|l|}
\hline Observed Mean Distance: & 67.417763 \\
\hline Expected Mean Distance: & 0.126592 \\
\hline Nearest Neighbor Ratio: & 532.557660 \\
\hline z-score: & 12701.165151 \\
\hline p-value: & 0.000000 \\
\hline
\end{tabular}

Figure 6.8: Average Nearest Neighbor of Masonic Lodge 271 in 1920. 


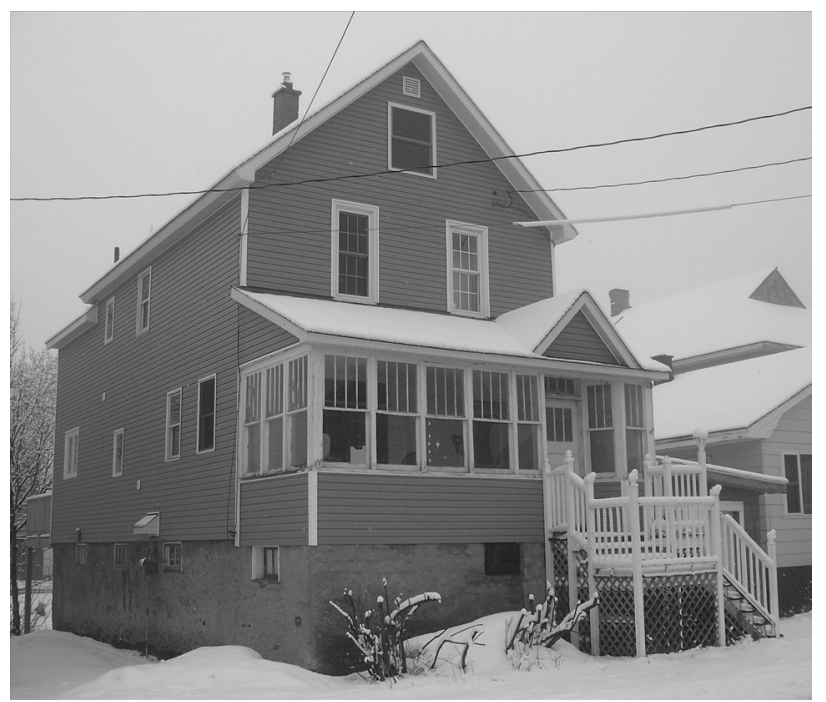

Figure 6.9: 118 Amygdaloid in Laurium, house of James Wilson. (Image by author)

The upper middle class house of William Galbraith differs significantly from the Wilson's middle class house. (Figure 6.10) Not only was the house more substantial in construction, it also had a poor rock foundation with sandstone quoins and a large front porch. While James Wilson's house had a small square open porch which was later expanded after 1917, Galbraith had a rectangular design with a cross gabled layout

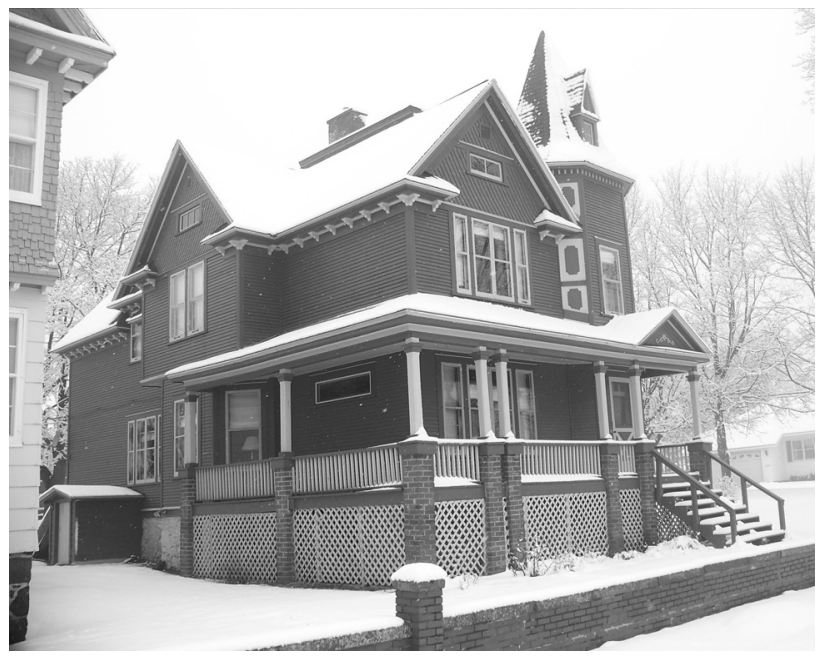

Figure 6.10: 205 Pewabic in Laurium, home to William J. Galbraith. (Image by author) ornamentation and gingerbreading

under the eaves. Galbraith's lot was

also larger than Wilson's (roughly

$30 \%$ ), and a wider street gave the

house a more impressive

appearance. Galbraith employed one 
servant, had a boarder, and a wife, two children, as well as his mother-in-law and father living with him. ${ }^{15}$ Even with five dependents, a boarder, and servant, Galbraith had more space per person than Wilson, fitting his economic standing in the community.

The last house to examine was Thomas Gribble, on $3228^{\text {th }}$ Street in Calumet. This house had more in common with Wilson's house in Laurium, Thomas Gribble worked as a shoemaker and belonged to the working class. While the shingle skirt hides the foundation, the house most likely was built with a poor rock foundation. The hipped roof, wood frame construction, and layout indicate it was most likely a single-family home. Interestingly, the Gribbles did not have any boarders in 1900, nor any servants but his five children lived with him, four of whom were employed. Two of his daughters - Phoebe and Florence - were teachers, Winifred was as a stenographer, and Arthur a private secretary. His youngest daughter Helen was still in school at the time, but with the entire family living together their combined income allowed them to have a house without the need for a boarder. ${ }^{16}$ Comparing Gribble's house with Galbraith and Wilson, enables the

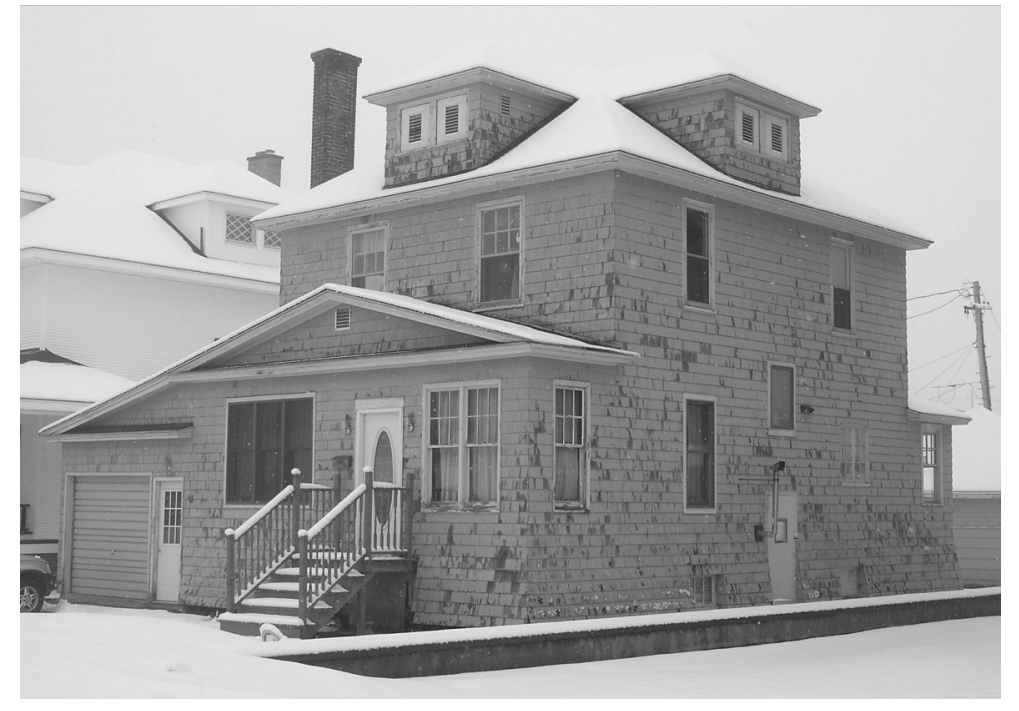

Figure 6.11: $3228^{\text {th }}$ Street in calumet, home to Thomas Gribble. (Image by author)

${ }^{15}$ U.S. Census of Population and Housing, 1901. 
class division in the 1900 Calumet area to be more pronounced. Yet all these men, from different classes and ethnic backgrounds, belonged to the same group. Within the liminal otherworldly lodge atmosphere they were all Masons. 


\section{Chapter 7: Masonic Ritual}

\section{Ritual Transformation}

Through the focus on "the sacred ritual over interpersonal relationships" Freemasons joined men from multiple backgrounds within the lodge, uniting them as brethren. ${ }^{1}$ Ritual was important because it provided the men with the knowledge needed to understand Masonic mysteries; each step to the next degree further illuminated the understanding of the moral code to which all Masons aspired. The moral code included treating all men, regardless of class, as equals and helped to democratize the order. Through ritual the effects of class and class differences among members are mitigated by a shared bonding experience of Masonic leveling. All initiates were symbolically made craft workers. With the ritual men from all economic backgrounds felt accepted into the Lodge, prompting men such as James Nankervis who worked as a bookkeeper to seek membership. He passed through the same refinement as Richard Jones, an upper middle class dentist and fellow Mason. Without the ritualistic leveling, working and middle class men might have felt resentment towards an elite Masonic membership. By removing the members from the world at large and placing them within the secluded, liminal setting of the lodge, they could relate to each other outside of Calumet's stratified society. Through the ritual, a profane outsider became a 'perfect ashlar stone' of Masonic refinement. This transformation equalized all Masons into a group of brethren; this process was one of the main reasons for men to seek membership within Lodge 271.

\footnotetext{
${ }^{1}$ Laurie A. Wilkie, The Lost Boys of Zeta Psi (Los Angeles: University of California Press, 2010), 3. 
The Masonic ritual of the mid nineteenth century onwards stood in stark contrast to the 'merry Masons' of 1800 . Before the anti-Masonic crusades of the 1820 s the group gathered in taverns and other local establishments. Around 1840 the Masons emerged "purged of alcohol and imbued with a sobering... ritualism." Money that had been spent on liquor and reinforcing the popular image of the 'merry Mason' went towards "expensive costumes and paraphernalia." More of the meeting time was occupied with "increasingly complex and time-consuming rituals." Through rituals Masonry gained acceptance by "reiterating middle-class values and by preaching a...doctrine of brotherhood." ${ }^{4}$ The ritual existed, according to fraternal scholars, to fill a universal need among men. By setting the ceremony within the Old Testament or other ancient times, they removed the contemporary issues of "ethnicity, work, and politics" from the "central concern of the ritual." Within the lodge the members were instructed not to "hold private committees or separate conversations," for they would jeopardize unity among lodge members. ${ }^{6}$ The ritual practices of the lodge took place within the Masonic Temple, which physically separated Masonic practices from the profane world at large. As Lévi-Strauss wrote, rituals were "entities independent of men's consciousness of them, although they in fact govern a groups existence." This was applied within the Masonic lodge, where the ritual was paramount to the lodge structure. The members did not see the ritual as a "repeated pattern of

\footnotetext{
${ }^{2}$ Carnes, Secret Ritual and Manhood, 79.

${ }^{3}$ Ibid, 25.

${ }^{4}$ Ibid, 89.

${ }^{5}$ Ibid, 107.

${ }^{6}$ Albert G.Mackay, Manual of the Lodge (New York: Maynard, Merrill, \& Co, 1898), 219.
} 
action...empirically observed and measured." ${ }^{7}$ However there was a difference between how the rituals were written within the Masonic monitors and how the members of the lodge enacted them.

Freemasonry's ritual embodied the unwavering belief in fraternal members both past and present. Men joined the lodge out of a desire to be a part of that long tradition. As a member progressed through the various degrees from Earned Apprentice to Master Mason he sought to learn the workings and demonstrate the tenets of the craft "in [his] daily life." ${ }^{8}$ Each member strove to be an "honorable and active [member] in the most noble Craft that has adorned the annals of the world's history." "9 The men felt compelled to seek admission to the Craft, each sought a fraternal bond or perhaps a call to be a part of something greater than themselves. Another reason that might lead a man to apply for membership was a desire to gain internal improvement. This involved following the lessons "taught to him on his initiation and afterwards... [that framed] his life [along] Masonic lines." ${ }^{10}$ The path to becoming a Master Mason, and upwards to Knights Templar in the York Rite, not only moved a man through each step of Masonic knowledge but sought to endue within him a moral code by which he could lead his life. A candidate learned he was "working for the friendship of the whole human family." "Freemasonry acts as a master gardener, and trains the human sapling in the direction of its own spiritual ideal...[and] is working for the friendship of the whole human

\footnotetext{
${ }^{7}$ Lévi-Strauss, quoted in Paul Bohannan II and Mark Galzer, eds. High Points in Anthropology (New York: McGraw-Hill, 1988), 506.

${ }^{8}$ Dudley Wright, The Ethics of Freemasonry (repr., Whitefish,MT: Kessinger Publishing, 2010), 3.

${ }^{9}$ Ibid, 3 .

${ }^{10}$ Ibid, 5 .
} 
family...bringing man near to man [and] man nearer to God." ${ }^{11}$ The candidate progressed up the Masonic steps as seen in the winding stairs of Masonic rituals, sold by firms such as the Henderson-Ames Company of Kalamazoo, Michigan. (Figure 7.1) ${ }^{12}$ The values of the lodge superseded class divisions, as members learned "selfreliance... and good moral character."13

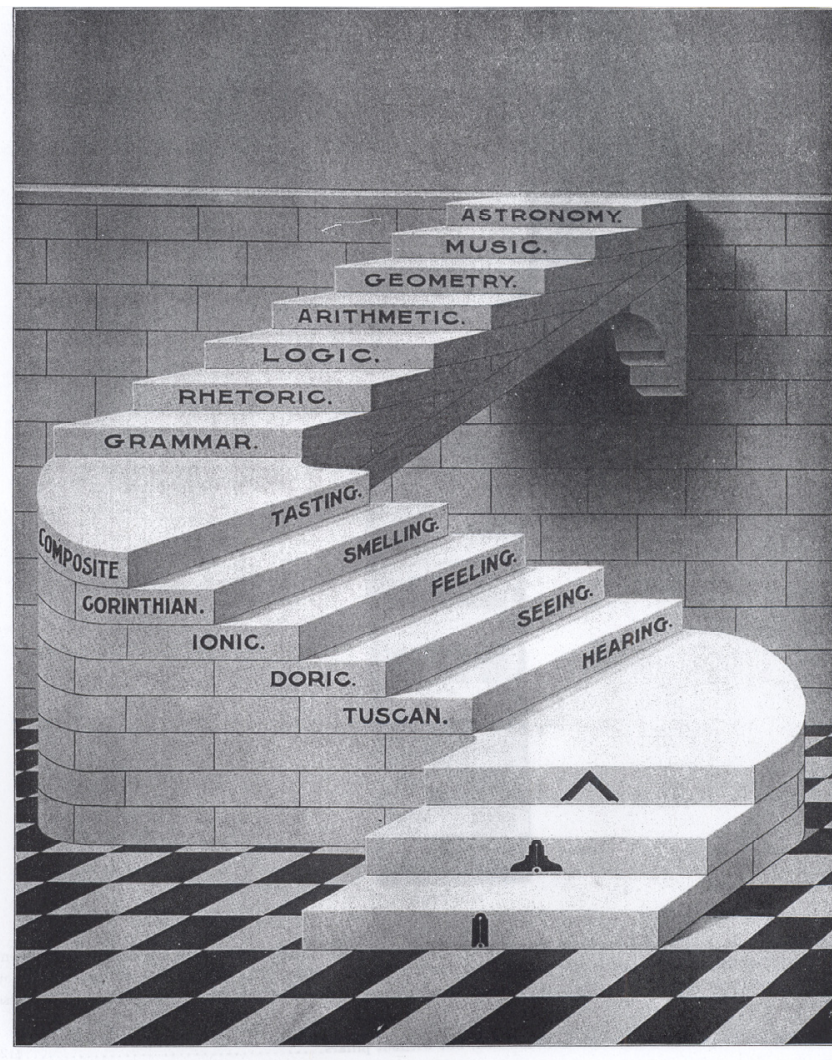

No. 1162

1162 Seven feet wide and niue feet. long. Artistically painted in oil colors, as seen in the above illustration on oileloth, making a beautiful p!ain and durable chart, mounted on a roller for shipmen and future preservation; eacls...

Figure 7.1: Masonic F.C. Winding Stairs.

Figure from The Henderson-Ames Company, F.C. Winding Stairs. ${ }^{12}$

\footnotetext{
${ }^{11}$ Dudley Wright, The Ethics of Freemasonry, 5-8.

${ }^{12}$ The Henderson-Ames Company, 80.

${ }^{13}$ David T. Beito, From Mutual Aid to the Welfare State (Chapel Hill: University of North Carolina Press, 1999), 27.
} 
"Coming from the ignorance and darkness of the outer world his first craving is for light - not that physical light which springs from the great orb of day as its fountain but the moral and intellectual light which emanates from the primal Source of all things - from the Grand Architect of the Universe"14

\section{William Drew in The Freemason's Hand-Book}

\section{Out-of-world Atmosphere}

Central to lodge membership was the "out-of-world atmosphere, which enveloped the scenes where men are knit together by the closest of ties," that transpired every week during the ritual setting. ${ }^{15}$ The Masonic ritual stood at the center of Masonic belief structure, and the Masonic charge was emphasized in the 9,000 lodges across the United States. In 1880 these numerous lodges "permitted much variation" from lodge to lodge. The variation was evident in not only in the lodge's location from "both rural and urban areas" but also the "composition of the lodges" that reflected class membership. ${ }^{16}$ The values that Masonry inculcated - "industry, sobriety, self-restraint, honesty, and fear of God" - were instilled in the candidate during the ritual and in the guidebooks candidates used to prepare for the ceremony. ${ }^{17}$ One of the most important characteristics of the Masonic lodge, the respect for God, could be seen in the religious aspect of the lodge, as exemplified in the Masonic Temple sign. Also the building where the lodge assembled was referred to as a Masonic Temple. (Figure7.2) The lodge setting paralleled organized religion, as the Bible stood "open at the altar; meetings were

\footnotetext{
${ }^{14}$ Drew, The Freemason's Hand-Book, 64.

${ }^{15}$ Carnes, Secret Ritual and Manhood, 2.

${ }^{16}$ Dumenil, Freemasonry and American Culture, 13.

${ }^{17}$ Ibid, 13.
} 
opened and closed with prayers; lodges had a chaplain; the ritualistic exchanges between Master and brethren resembled responsive readings." ${ }^{18}$ This all centered on the dramatic pageantry of the lodge meeting.

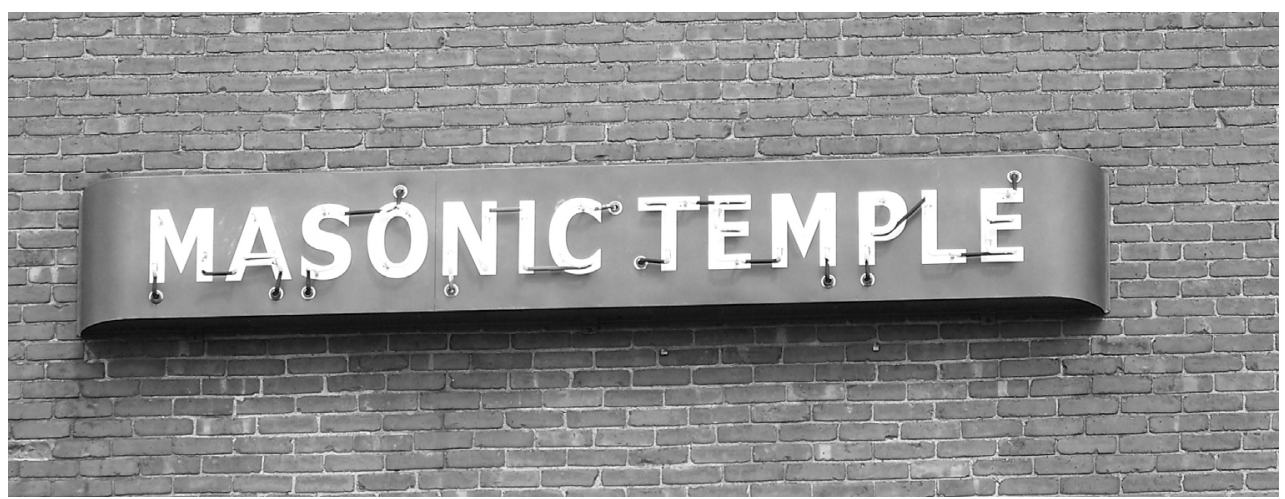

Figure 7.2: Masonic Temple Sign, in Calumet, MI on Lodge 271's hall. Currently it serves as the visitor center for the Keweenaw National Historical Park. (Image by author)

The 1900 Los Angeles Freemason remarked that "Masonry has no creed but the fatherhood of God...Masonry is the world's religion." Members reinforced their acceptance of the religious wording and orientation in ritual practice. ${ }^{19}$ This included: the Bible at the center of the ritual of the first three degrees, variously called the 'craft,' 'symbolic,' or 'blue lodges,' that defined Masonry. ${ }^{20}$ On the side of the altar three white candles were arranged "in the shape of a right triangle" that reinforced the sacred atmosphere of the lodge. ${ }^{21}$ As Dumenil noted, the aura of the Masonic Temple emphasized the "sacred quality of the order" in the churchlike setting. American Freemasonry's ritual originated in English traditions and existed to "disclose secret

\footnotetext{
${ }^{18}$ Dumenil, Freemasonry and American Culture, 31.

${ }^{19}$ Ibid, 49.

${ }^{20}$ Moore, Masonic Temples, 1.

${ }^{21}$ Carnes, Secret Ritual and Manhood, 39.
} 
passwords and recognition signals." ${ }^{22}$ The Americans did away with them almost entirely - resulting in the theatrical Masonic ritual.

Each of the first three Masonic degrees served as a rite of passage transforming a "profane outsider to [a brother] occupying a position of equality with other Masons." 23 Within this study, Viktor Turner's notion of the transformative nature of groups is applied to the Masons. They underwent an act of leveling "in which signs of their preliminal status were destroyed and signs of their liminal non-status applied." 24 Through Masonry the candidate learned the "foundation on which Masonry rests" - a supreme being. His acknowledgement of that being provided him with "sure confidence... [to] protect his steps in all the dangers and difficulties he [would be] be called to encounter in his progress through life." ${ }^{25}$ Once the candidate earned the first degree - Entered Apprentice - they gained knowledge in the "Masonic alphabet, and...the fundamental principles of this time-honored institution." 26 The Entered Apprentice moved from the outside world through the liminal ritual, or the transformative atmosphere, as part of the larger Masonic ritual. It "prepare[d] the candidate for the higher and fuller instructions of succeeding degrees." 27 Through the first degree the individual was introduced to the symbols of the craft, from the white leather apron, to the twenty-four inch gauge, and the common gavel. He learned the symbolism of moral guidance as he underwent instructions in the "moral architecture"

\footnotetext{
${ }^{22}$ Carnes, Secret Ritual and Manhood, 22.

${ }^{23}$ Dumenil, Freemasonry and American Culture, 39.

${ }^{24}$ Turner, From Ritual to Theatre, 26.

${ }^{25}$ Drew, The Freemason's Hand-Book, 36.

${ }^{26}$ Ibid, 36.

${ }^{27}$ John R. Bennett, The Origin of Freemasonry and the Knights Templar (repr., Whitefish,MT: Kessinger Publishing, 2010), 85.
} 
of the craft. ${ }^{28}$ The second degree added more symbols to the initiate's vocabulary. Upon undergoing the third degree the individual, portraying Hiram Abiff, was 'killed' during the ceremony for failing to turn over the secrets of Masonry. Hiram Abiff, according to Masonic lore, was the mason that designed Solomon's Temple, and killed for refusing to share his craft with the laborers building the temple. In the ritual the candidate was reborn and incorporated into the Masonic body. He left the profane world behind and was "raised incorruptible" the divine lodge. ${ }^{29}$

The Masonic ritual was paramount in the organization and "the importance of ritual to late nineteenth-century Masonry is indicated by the extensive attention officials...gave it." 30 Some Masons believed that the "prosperity of a Lodge [was] indicated by the number of its members. ${ }^{, 31}$ Others thought that little was paid to the character and qualification of the candidate [as they rushed] through the degrees." ${ }^{32}$ As the order reached the twentieth century the rituals became a central tenet of the organization nationwide. The Michigan Grand Lodge insisted on a uniform ritual to avoid having the language of it obscured as many lodges "exhibited a strange departure from the ancient Landmarks [of the ritual]. ${ }^{, 33}$ Without a uniform ritual practice the work of two lodges "scarcely correspond[ed] in unity and harmony." 34 The Grand Lodge sought to bring the ancient and genuine ritual into the lodge meeting. To reinforce the unity of the lodges Michigan had inspectors "visit lodges and [to insure]

\footnotetext{
${ }^{28}$ Drew, The Freemason's Hand-Book, 42.

${ }^{29}$ Michigan Masonic Monitor (Detroit: The Grand Lodge of Michigan, 1897), 29.

${ }^{30}$ Dumenil, Freemasonry and American Culture, 32.

${ }^{31}$ Conover, Freemasonry in Michigan, 10.

${ }^{32}$ Ibid, 10.

${ }^{33}$ Transactions of the Grand Lodge of the State of Michigan, 15.

${ }^{34}$ Ibid, 15.
} 
that their ritual conformed" to the rites and ceremonies that stood upon the tradition of thirty centuries." ${ }^{35}$ The emphasis on ritual, and the Grand Lecturer who visited lodges to inspect ritual performance, reinforced the ancient origins of the craft and guided the lodge members towards proficiency in their craft. ${ }^{36}$ Through ritual the Masons "retained a substantial uniformity, independent of...time and place." ${ }^{37}$ The Masons portrayed the ritual as "evidence of the changelessness and importance of Masonry itself," through the ritual uniformity - prestige was portrayed. ${ }^{38}$ "Thus has Masonry ever done; thus will she ever do., 39

\section{Ritualistic Symbolism: The Blue Lodge}

The introductory ritual had a deeply symbolic for the members of the lodge. As defined by Bennett, in Freemasonry and Knights Templar, the rite was a "method of conferring Masonic light by collection and distribution of degrees." ${ }^{40}$ Within the ritual, brothers escaped into an "asylum from the secular or profane world outside the temple." ${ }^{41}$ This demarcation was maintained through an emphasis on secrecy in regards to lodge business because "religion, politics and business could not be considered within the lodge walls," thus keeping the two worlds apart. ${ }^{42}$ The strife from the outside world did not enter through the "well-guarded portals" of the lodge guarded by the

\footnotetext{
${ }^{35}$ Dumenil, Freemasonry and American Culture, 32, Transactions of the Grand Lodge of the State of Michigan, 15.

${ }^{36}$ Transactions of the Grand Lodge of the State of Michigan, 21.

${ }^{37}$ Ibid, 15.

${ }^{38}$ Dumenil, Freemasonry and American Culture, 33.

${ }^{39}$ Transactions of the Grand Lodge of the State of Michigan, 15.

${ }^{40}$ Bennett, The Origin of Freemasonry and the Knights Templar, 81.

${ }^{41}$ Dumenil, Freemasonry and American Culture, 38.

${ }^{42}$ Ibid, 38.
} 
Tyler. ${ }^{43}$ The candidates for membership sought to "embark upon a journey to discover for themselves" the lost Word of God, as they "lacked that crucial knowledge." ${ }^{, 44}$ When the initiate entered into the lodge they were "thrown to the floor, bound and carried to the preparation room" and charged with rebuilding the temple at Jerusalem. ${ }^{45}$ The initiates struggled towards Jerusalem where they were "denied entrance to the construction site...until they spoke the secret phrase. ${ }^{, 46}$ The candidates stood at the threshold to a new life, a symbolic rebirth and in "darkness, helplessness, and ignorance" until the trapdoor was discovered under the temple, opening their eyes to the Masonic mysteries. ${ }^{47}$ The initiate discovered three squares of past Grand Masters, “manna, Aaron's rod, and the 'long lost book of the law'." These items linked Masonry with the Biblical past and guided the candidate towards a fuller understanding of Masonic writ. ${ }^{48}$

Each degree educated the candidate in the symbolism of the ritual and accepted behavior of each member. In the first degree, the Entered Apprentice, the candidate studied "moral architecture" that "maintain[ed] the propriety of [their] rites" and "illustrate[d]...which might lead [them] to error." Also important within the ritual is the 'badge of a mason,' or the lambskin apron. It is an emblem of innocence, reminding the candidate "that purity of life and conduct" is expected of a Mason both within and outside of the lodge. ${ }^{49}$ The candidate also had the lodge orientation and features

\footnotetext{
${ }^{43}$ Transactions of the Grand Lodge of the State of Michigan, 32.

${ }^{44}$ Carnes, Secret Ritual and Manhood, 44.

${ }^{45}$ Ibid, 44.

${ }^{46}$ Ibid, 44.

${ }^{47}$ Dumenil, Freemasonry and American Culture, 39.

${ }^{48}$ Carnes, Secret Ritual and Manhood, 45.

${ }^{49}$ Drew, The Freemason's Hand-Book, 42-43.
} 
explained to him, from the east-west orientation to the Masonic pavement, Indented Tessel and Blazing Star ornaments. Each of these built on the Masonic heritage; Masons used the pavement as a "representation of the ground floor of King Solomon's Temple" and it is "emblematical of human life, checkered with good and evil." $"$ At the center of the Lodge, and the focal point of the ritual, was the Bible on the altar that reminded the Mason that their service was dedicated to the service of God. Behind the altar was the seat of the Grand Master for the lodge, with a rough and perfect ashlar stones on either side. In moving from Entered Apprentice through the degrees the initiate emulated the stone. The perfect ashlar reminded the candidate of the "state of perfection at which [they] hoped to arrive" after entering into the lodge as rough ashlar prior to initiation, in need of Masonic refinement. ${ }^{51}$

\section{The First Three Steps}

"They now bid you welcome to their number and fellowship, to their affection and assistance, to their privileges and joys; and through me [Worshipful Master] they promise to protect you by their influence and authority...to advise you...to assist you....and to cheer you"

The Freemason's Handbook, p.66-67.

Those are the lines the Worshipful Master spoke when welcoming a new member into the first degree of Masonry, the "beginning of our art" that "will lead you

\footnotetext{
${ }^{50}$ Drew, The Freemason's Hand-Book, 48-49.

${ }^{51}$ Ibid, 54 .
} 
forward to higher degrees. ${ }^{, 52}$ The Masonic ritual provided an opportunity for religious experience. As noted by Bronislaw Malinowski in Magic, Science and Religion, the ritual served as an "efficient mean of transmitting...lore, or insuring continuity in tradition. ${ }^{, 53}$ When applied to Masons it reinforces why they invested their time and effort into the ritual practices; by having a standardized ritual they maintained cohesion for the group and the "personal impact on the individual should not be underestimated. ${ }^{, 54}$ During the preparation for the third degree the candidate was informed that it was "calculated to bind men together... as in a bond of fraternal affection and brotherly love," which set the stage for brotherly equality in the lodge setting. All those who earned the third degree were also able to become lodge officers because they were "capable of giving instructions, that [they could] reasonably [be expected] to receive it." ${ }^{\text {} 55}$ The cement of brotherly love that the Masonic trowel spreads, like the mortar in a building, united the group as one.

The second degree for a Mason to earn was the Fellow Craft. Through this degree a candidate learned of the five senses that allowed the Mason to go about his craft. The three key senses are hearing, seeing, and touching with "sight the noblest" faculty. ${ }^{56}$ These faculties also allowed him to reason and apply Masonic teachings to his life at the seven liberal arts and sciences from grammar to music. Grammar allowed a Mason to "speak with propriety, precision, and purity" which paired with rhetoric,

\footnotetext{
${ }^{52}$ Drew, The Freemason's Hand-Book, 67.

${ }^{53}$ Bronislaw Malinowski and Robert Redfield, Magic, Science and Religion and Other Essays (repr.,Whitefish,MT: Kessinger Publishing, 2004), 23.

${ }^{54}$ Dumenil, Freemasonry and American Culture, 41.

${ }^{55}$ Drew, The Freemason's Hand-Book, 101.

${ }^{56}$ Ibid, 87.
} 
arithmetic, geometry and astronomy and logic. Though it is through geometry, the "first and most noblest of sciences," by tracing nature the universe's apparent order it is reveled to a Mason. "Through reason and nature," he comes "out of ignorance and into knowledge." 57

Upon receiving the third degree the Mason was charged to "conform to the principles of the order." ${ }^{, 58}$ A guide to the Master Mason in The Freemasons Hand-book, Drew describes the symbolism needed by the third degree, to prove their Masonic knowledge. Having gained the meaning behind the "hour-glass with its swiftly flowing grains" reminded the Masons that life eventually drew to a close, and to the scythe "which cuts the brittle thread of life," mortality was reinforced throughout the third degree. ${ }^{59}$ Due to this the Masons felt charged with correcting the faults of their less informed brethren, to "fortify their minds," to their equals in rank or office "courtesy and respect" are due, and to one's superiors "kindness and condescension." ${ }^{60}$ Mutual acts of kindness preserved the order, the respect due to each other truly made members equal within the lodge. This is seen in the variation in the lodge officers, who were not all upper middle or upper class, but men from all classes of society - equal in the lodge setting.

The ritual process as described by Turner helps to understand the transformation that made the Masons symbolically craft workers, equals among each other. Turner's ritual involved separation of the individual from the general public, a transformative or

\footnotetext{
${ }^{57}$ Dumenil, Freemasonry and American Culture, 36, Drew, The Freemason's Hand-Book, 94-97.

${ }^{58}$ Ibid, 37.

${ }^{59}$ Drew, The Freemason's Hand-Book, 123.

${ }^{60} \mathrm{Ibid}, 128$.
} 
liminal phase, and reintegration into the larger community. In this study, its applied to mean the reintegration into not only the community at large but also the Masonic Lodge. Also the members presiding over the transformation were "segmentalized into roles which [they] play," what Radcliff-Brown has called "persona, the role-mask, not the unique individual," where one individual might portray multiple personas over the evening, or multiple people might portray one persona ${ }^{61}$ This persona is seen within the ritual, as those who already took the oath as Master Mason underwent the ritualistic transformation through their role-mask each meeting. This allowed a greater understanding of Masonry to current members while instilling the ideals into a new generation of Master Masons.

The ritual formed a "distinct phase in the social process" of Masonic advancement whereby a member "adjusted to [the] internal changes" through the first three degrees of Masonry. ${ }^{62}$ The Masonic symbols such as the ashlar stone, the apron, and working tools "[became] a factor in social action, a positive force in an activity field;" the ritual process reinforced the moral code to which all members aspired. The Masonic ritual outlined by ethnographer Arnold van Gennep in Rites de Passage. In his work rites of passage have two meanings, but the one that is important to Masonic transformation is "ritual accompanying an individual or cohort of individuals change in social status. ${ }^{63}$ Van Gennep noted three stages in the ritual transformation beginning with the separation of the individual from society at large - from the profane world

${ }^{61}$ Bohannan, High Points in Anthropology, 507.

${ }^{62}$ Turner, From Ritual to Theatre, 21-22.

${ }^{63} \mathrm{Ibid}, 22-24$. 
outside the lodge. During the ceremony or ritual the candidate was in limbo, in a transition from a non-Mason to Mason, betwixt and between two stages of their life.

Turner's theory rested on the recognition that ritual is not an “'epiphenomenon' but has 'ontological status'." Ritual is "part of the process of social change, given its capacity to generate new... social arrangements." ${ }^{64}$ It does not "mirror nor rest on the surface of more fundamental social processes. ${ }^{, 65}$ However with Turner's definition that "social-structural prescriptions have been relaxed" does not fit in with the Masonic model entirely, as even though the ritual both creates and dissolves liminal states, the ritual still follows a prescribed path codified in the Masonic monitors. ${ }^{66}$ Thus the Masons formed what Turner described as a "normative communitas," or the spirit of community, a "perduring social system.... a group which attempts to maintain relationships or spontaneous communitas on a more or less permanent basis. ${ }^{.67}$ Unlike a group that arose from "some 'natural' or technical 'necessity," the Masonic communitas formed within the ritual is based on an ideological belief. This communitas also took its meaning through its relationship to the outside world and the interaction between the sacred and profane. ${ }^{68}$ Through the ritual members proved themselves worthy of Masonry, entered into this social system, and attended meetings at the hall.

The whole system emulated the "symbolic idea of man passing through the pilgrimage of life," with the man emerging into maturity as a Master Mason and gaining

\footnotetext{
${ }^{64}$ Bobby C. Alexander, Victor Turner Revisited (Atlanta: Scholars Press, 1991), 19.

${ }^{65}$ Ibid, 19.

${ }^{66}$ Ibid, 19.

${ }^{67}$ Turner, From Ritual to Theatre, 49.

${ }^{68}$ Ibid 50.
} 
"proficiency in the 'craft' of Freemasonry." ${ }^{, 69}$ After he earned the third degree the individual gained the right to "sign his name on the roster, to attend meetings, to speak and vote in lodge...wear the lambskin apron at meetings and the square and compass on his street clothes." Now integrated into the lodge the new Mason displayed his membership to the "profane' world outside the lodge. This set him "apart and above" from non-Masons. ${ }^{70}$ Older members of the lodge underwent the ritual transformation by participating in the ceremonies. They were reminded that they were "members of an important and mysterious organization" and "reaffirmed[ed] their allegiance to Masonry and its teachings." ${ }^{, 71}$ On lodge nights the Masons used the ceremonies to "promote [a] communal solidarity" between each other and between different lodges. ${ }^{72}$ By passing through the three degrees the Mason gained entrance into the inner temple, and only in the presence of other Master Masons was full lodge voting and practices carried out. Historian Arthur Schlesinger stated that fraternities enacted the ritual once a year and forgotten tucked it away until the next year. The Masons used the ritual as a vital part of the group identity. The Masonic ritual was "long and complex; nearly all required well over an hour to perform.."73 The ritual was also important from a numerical standpoint, with thousands of men undergoing the process annually.

\footnotetext{
${ }^{69}$ Bennett, The Origin of Freemasonry and the Knights Templar 86, Moore, Masonic Temples, 4.

${ }^{70}$ Dumenil, Freemasonry and American Culture, 39.

${ }^{71}$ Ibid, 39.

${ }^{72}$ Ibid, 3940.

${ }^{73}$ Carnes, Secret Ritual and Manhood, 4.
} 


\section{Chapter 8: Masonic Temples}

\section{Calumet's Union Building}

"Just as a church stands for spiritual life, the school for educational, the factory for commercial, and the residence for the home, so does this new Temple have a peculiarly definite significance in the community... [the building] stands for a certain spiritual

$$
\text { factor." } 1
$$

Masonic Lodges became ubiquitous parts of most American cities and towns throughout the country at the end of the nineteenth century, from "simple frame structures to magnificent exotic piles."2 Calumet's Union Building sits on the corner of Fifth Street and Red Jacket Road, in Calumet Township, bordering Calumet's primary commercial street and gateway. Masonic Lodge 271 built their structure with the aid of the Independent Order of Odd Fellows, Hecla Lodge 90. This began on Friday, May 11, 1888 when a "prospectus was circulated among the citizens of Calumet, Michigan for signatures."3 The reason behind the construction of a purpose-built structure was given as "quite a number of the members of Calumet lodge of Free and Accepted Masons [were] desirous of having a more commodious lodge room, and Hecla lodge of Odd Fellows [also wanted] a lodge room." 4 The Masonic hall on the third floor removed the sacred space of the lodge from the view of the outside world. In 1874 Christopher G. Fox, Grand Master of New York State remarked lodges should be on the third floor or above - "I do not like the idea of holding Lodge meetings in the second story of a

\footnotetext{
${ }^{1}$ Moore, Masonic Temples, 1.

${ }^{2}$ Ibid, 1.

3 "Union Building Association of Calumet records," 1888. MTU \& CCHC, 2.

${ }^{4}$ Ibid, 2.
} 
building...I am inclined to think it will not do for a Lodge Room.." To provide funding for the lodge the Masons and Odd Fellows formed a building association "or stock company, provided a sufficient amount of stock [would be] subscribed to warrant the undertaking," with the purpose of "erecting a good and commodious building." the Union Building Association sought to issue six hundred shares at twenty-five dollars apiece. After 572 shares were subscribed the Association set about "opening stock subscription books." ${ }^{, 7}$ In June of that same year the officers for the Association were elected, with R.H. Osborn elected as chairman and H.K. Cole secretary. At the first meeting they adopted a mission statement to:

"Erect, own, occupy, lease or sell a building, on lands of the Calumet and Hecla Mining Company, in the Township of Calumet and County of Houghton, which building shall be suitable for, and shall contain Lodge Rooms for the meeting of Calumet Lodge 271 F\&AM, and Hecla Lodge No. 90 IOOF, and also such stores or office rooms for rent or use as the director shall determine." ${ }^{n}$

The Association built a structure, with the chief financiers having bought 600 shares led by John Duncan, 20, John S. Morrison, 20, Charles Geiger, 4, Thomas Hoatson 6, Jacob Reuther, 4, H.K. Cole, 8, F.A. Kohlhaas, 10, W.C. Watson, 10, and R.H. Osborn with 518. It is no surprise that the Masons elected Osborn as one of their first Worshipful Masters in 1880 and the rest of the individuals stood at the foreground of the other fraternal groups seeking to use the building.

\footnotetext{
${ }^{5}$ Moore, Masonic Temples, 26.

6 "Union Building," 2.

${ }^{7}$ Ibid, 5 .

${ }^{8}$ Ibid, 5 .
} 
The meeting minutes from the Union Building Association survive from its inception in 1888 until 1914. This ledger provides insight and historic context for the building as an active part of the Calumet community. After tendering bids for the design the Association selected B.H. Pierce \& Co. from Hancock, MI to design the three-andone-half story brick building. Its completion was scheduled for 1889 at total projected cost of $\$ 18,000$. The growth of fraternal groups in Calumet was part of the larger goal of the Calumet and Hecla Mining Company to "shape the social infrastructure" and provided a "stable, productive, and loyal workforce." donation of the land to the lodges. While the Union Building Association was still in the planning stages the Masons met at the Calumet and Hecla administrative office in Calumet. When completed the Union Building accommodated over twenty of Calumet's "fraternal groups, benevolent organizations, and allied societies" that made use of the building, giving the building "significance in the area of social history, representing the role of fraternal organizations" in the community. ${ }^{10}$

By the time the Masons occupied the building in August of 1889 the total cost had risen to $\$ 23,000$. Like most Masonic halls of the period in small communities, the Union Building "included commercial space on the ground floor." The Merchants and Miners Bank expressed interest in renting space while the building was still in the planning stages. ${ }^{11}$ The building had a bank on the south side of the first floor and on the north side retailer sold "dress goods, trimmings, and fancy goods." These two commercial tenants allowed the Masons and Odd Fellows to use the space without

\footnotetext{
${ }^{9}$ Union Building Historic Structure Report (Draft) (Calumet,MI: Keweenaw National Historical Park, 2002), 2.

${ }^{10}$ Ibid, 8

${ }^{11}$ Ibid, 2.
} 
much direct cost. A vernacular building, the "Union Building was ornamented with decorative elements used throughout Calumet's commercial district: metal cornices, and columns, and sandstone wall trim." ${ }^{12}$ It formed part of a "continuous wall of façades extending north along Fifth Street. ${ }^{, 13}$ Like the local talent that designed and constructed the building, local components such as Jacobsville sandstone and poor rock were used in its construction. The later addition of a blue-tone metal sign along the southwest corner of the second floor façade that read "MASONIC TEMPLE" in neon bulbs, acted as a beacon for those seeking a Masonic connection.

\section{Lodge Organization}

In Masonic ritual what "happened within the space [is] more relevant to the lodge than the space itself." ${ }^{\prime 14}$ This difficulty in understanding the Lodge hall comes from the secret symbols and actions that are "not easily translated by an outside viewer [as] to the untrained eye [they said] little." ${ }^{, 15}$ Men who already belonged to Lodge 271 could enter directly into the lodge room from the anteroom, although the door was equipped with a lock and a peephole. While the meetings were in secession the Tyler sat at the door with a sword, guarding the entrance. Within the anteroom a second door on the north side of the room removed the candidate in preparation for the ritual. Within the candidate's room the intiate donned the ritual attire. For the Entered Apprentice this was "barefoot, [having removed] his outer clothing and has all metal objects [were] taken away [and was given] a slipper on his right foot and a pair of pants to wear; a

\footnotetext{
${ }^{12}$ Union Building Historic Structure Report, 20.

${ }^{13}$ Ibid, 20.

${ }^{14}$ Stephanie K. Atwood, Historic Use of the Interior Space of the Union Building (Calumet,MI: Keweenaw National Historical Park, 2008), 9.

${ }^{15}$ Ibid, 9.
} 
noose, usually of blue silk, [was] put on his neck and he was 'hoodwinked'." ${ }^{16}$ This symbolically meant the Masons accepted men when they were "penniless, wandering, and unclothed" - he was not accepted for material gain but out of brotherly respect. Within the Union Building, the candidate entered into the lodge blindfolded through the 'candidate's doors', a set of double doors in the northwest corner of the lodge hall. Upon entering the lodge the candidate underwent the 'Shock of Entrance.' This was a set of questions regarding his intentions; they informed the candidate should he reveal Masonic secrets he would "have [his] throat cut, [his] tongue torn out by the root, and buried in the sand of the sea at low water mark. ${ }^{, 17}$ This progression only occurred if the meeting contained 'floorwork' or 'degree work,' otherwise the costume room could be used by Masons to prepare for the meeting. (See Figure 8.5 for a layout of the Union Building's third floor during the initiation ritual, and Figure 8.2 for the movement taken by a candidate during the process). ${ }^{18}$

Within the ritual, the candidates and Masons relived the "mythic concept of ritual time and space," as the membership "transcend[ed] time" back to King Solomon. ${ }^{19}$ Men "existed simultaneously in their own chronology, in ancient Israel, and in all eras between." In a sense the men were part of both worlds concurrently but not completely in either. ${ }^{20}$ This brought the Masons into the timeless ceremony. The lodge room served as a "space disconnected from chronological time" and

\footnotetext{
${ }^{16}$ Atwood, Historic Use of the Interior Space of the Union Building, 12.

${ }^{17}$ Ibid, 12-13.

${ }^{18}$ Ibid, 14-15.

${ }^{19}$ Moore, Masonic Temples, 18.

${ }^{20}$ Ibid, 18.
} 


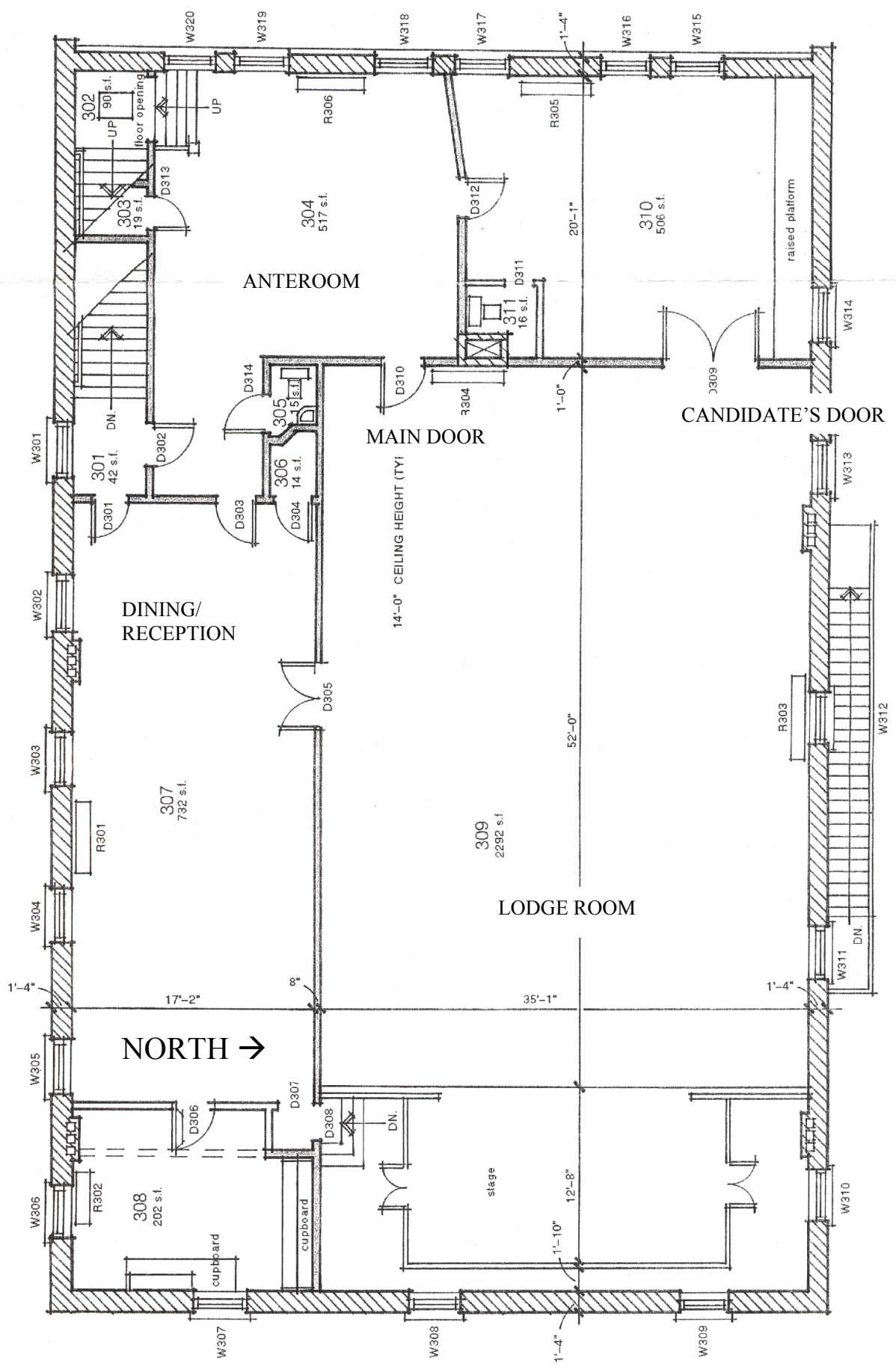

Figure 8.1: Layout of the Union Building's Third Floor, modified from S. Atwood's Historic Use of the Interior Space of the Union Building. ${ }^{18}$ 


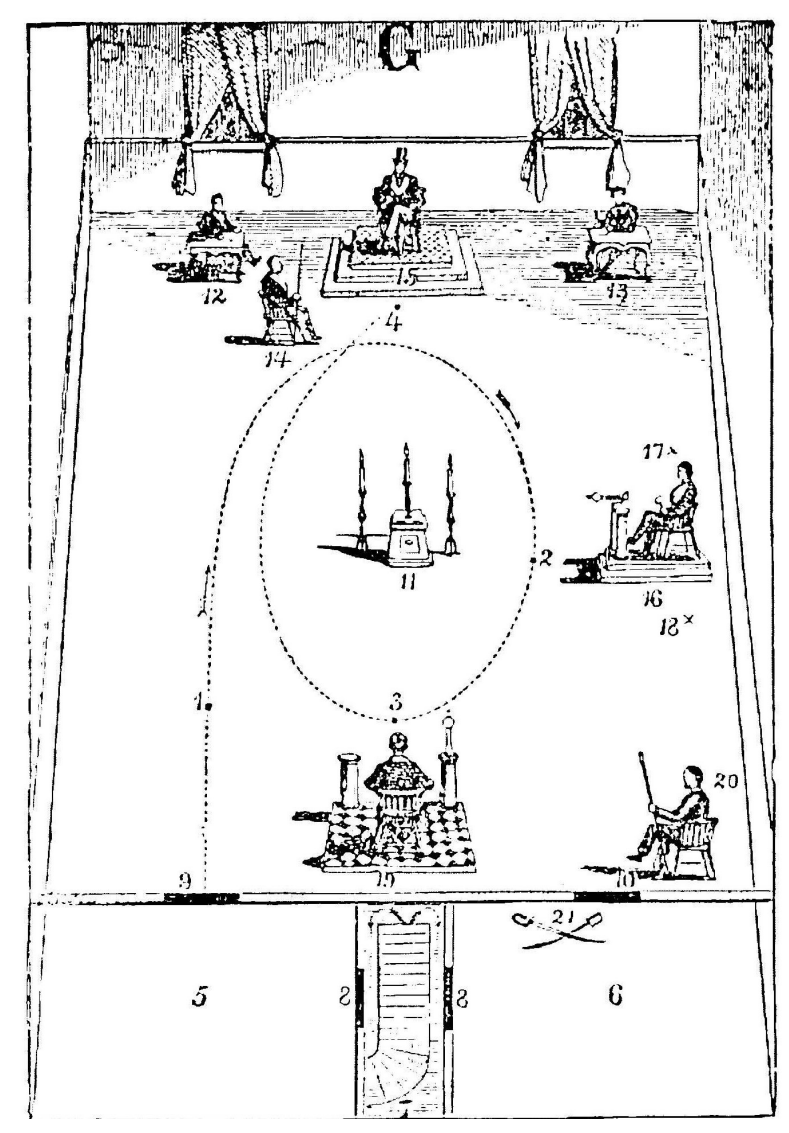

Figure 8.2: Movement taken by the candidate during the ritual process. From Duncan's Ritual and Monitor of Freemasonry. ${ }^{21}$

also as a space that excluded all nonmembers. ${ }^{22}$ Even while the members separated themselves from the world at large, it was still an active part of the larger community. The lodges relied on word-of-mouth to create interest in the organization. Like most 'secret' societies they advertised in the Polk Directory and also in local newspapers. In the summer of 1908 for example, the Calumet Lodge 271 published ads in the Calumet News multiple times from July to September informing the community that a "regular communication of Calumet Lodge No. 271 F\&AM will be held Thursday evening,

\footnotetext{
${ }^{21}$ Malcolm C. Duncan, Duncan's Ritual and Monitor of Freemasonry (New York: Dick \& Fitzgerald, 1866), 8.

${ }^{22}$ Moore, Masonic Temples, 18.
} 
August $6^{\text {th }}$ at 7:30 o'clock J.J. Ellis Jr. WM Pierce Roberts Sec'y., ${ }^{, 23}$ Also on lodge nights the lantern affixed to the front of the Union Building was lit, with the Masonic glass panes set in the lantern. (See Figures 8.3 and 8.4) Each group that used the building for meetings had their own glass panes, to inform the public which group was meeting in the hall that night.

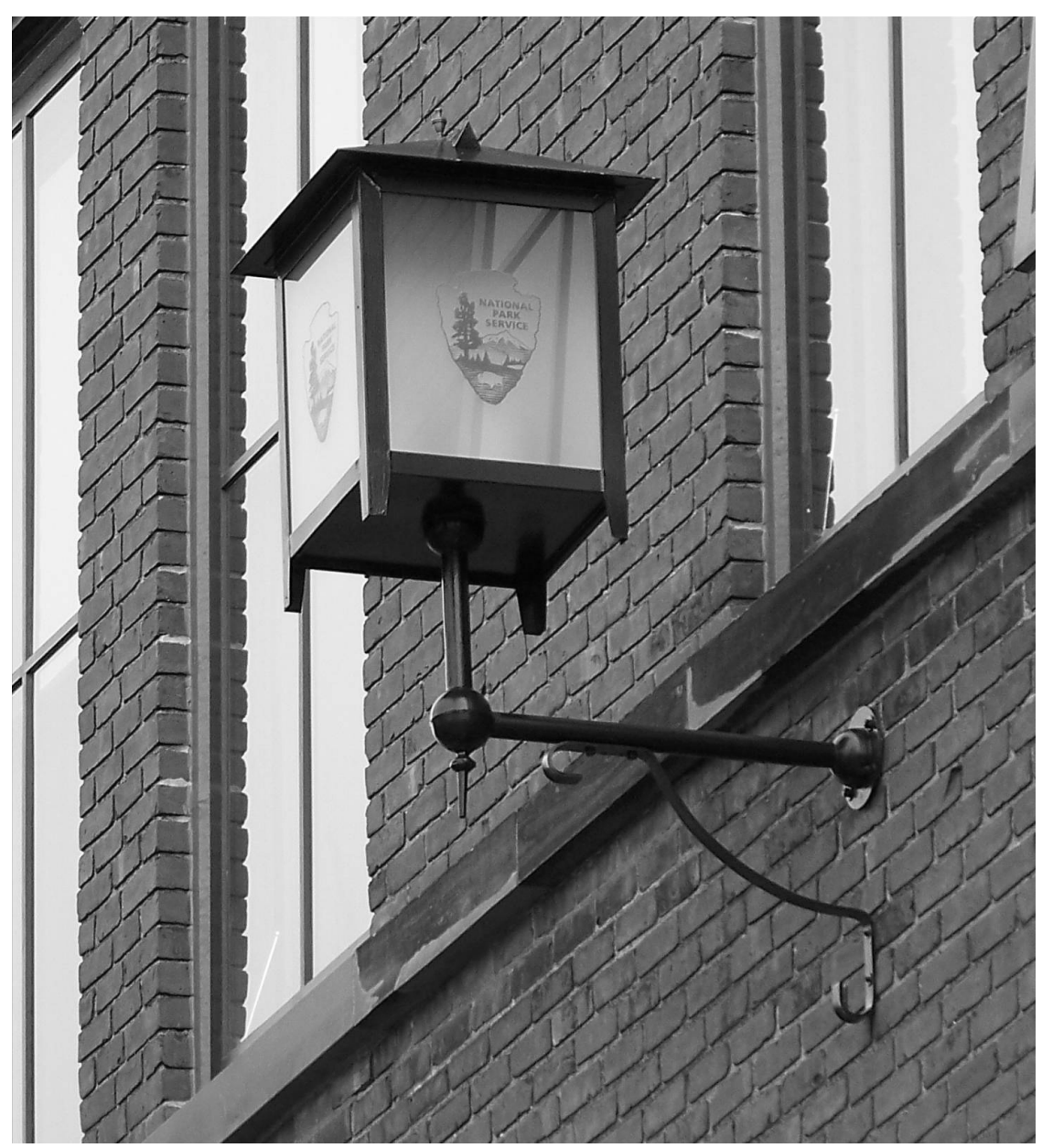

Figure 8.3: Reproduction of the lantern lit during meetings. (Image by author)

${ }^{23}$ Calumet News, August 4, 1908, MTA\&CCHC, 8. 


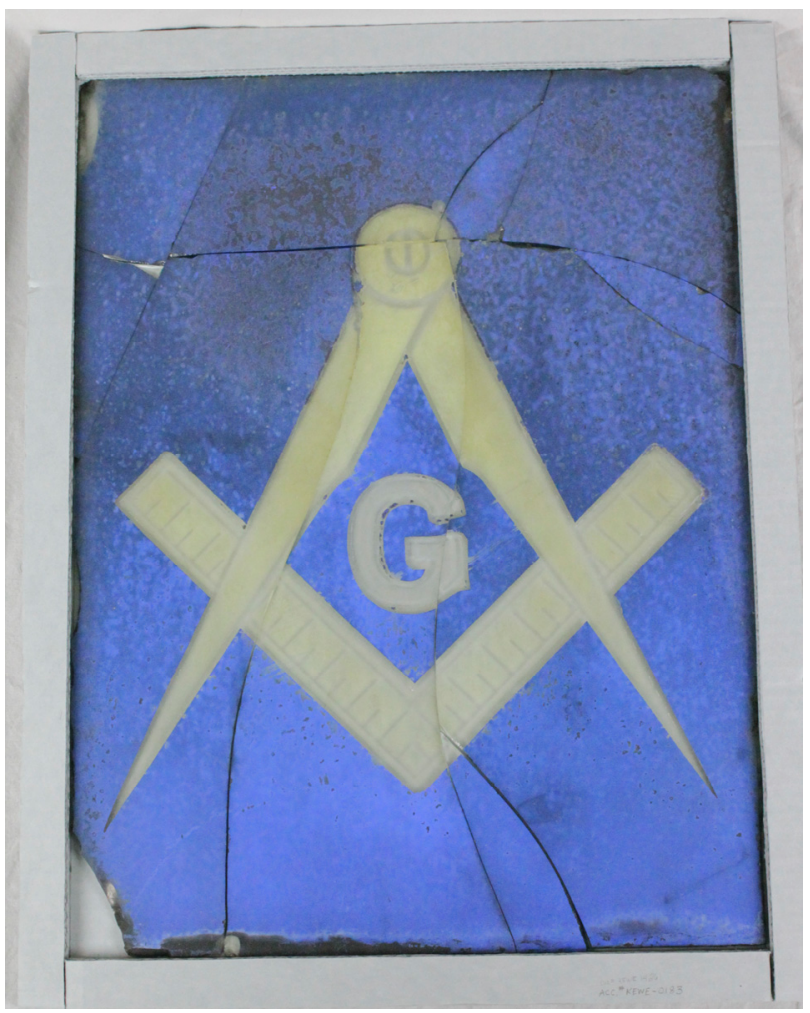

Figure 8.4: Lantern pane used by Masonic Lodge 271. (Image by author)

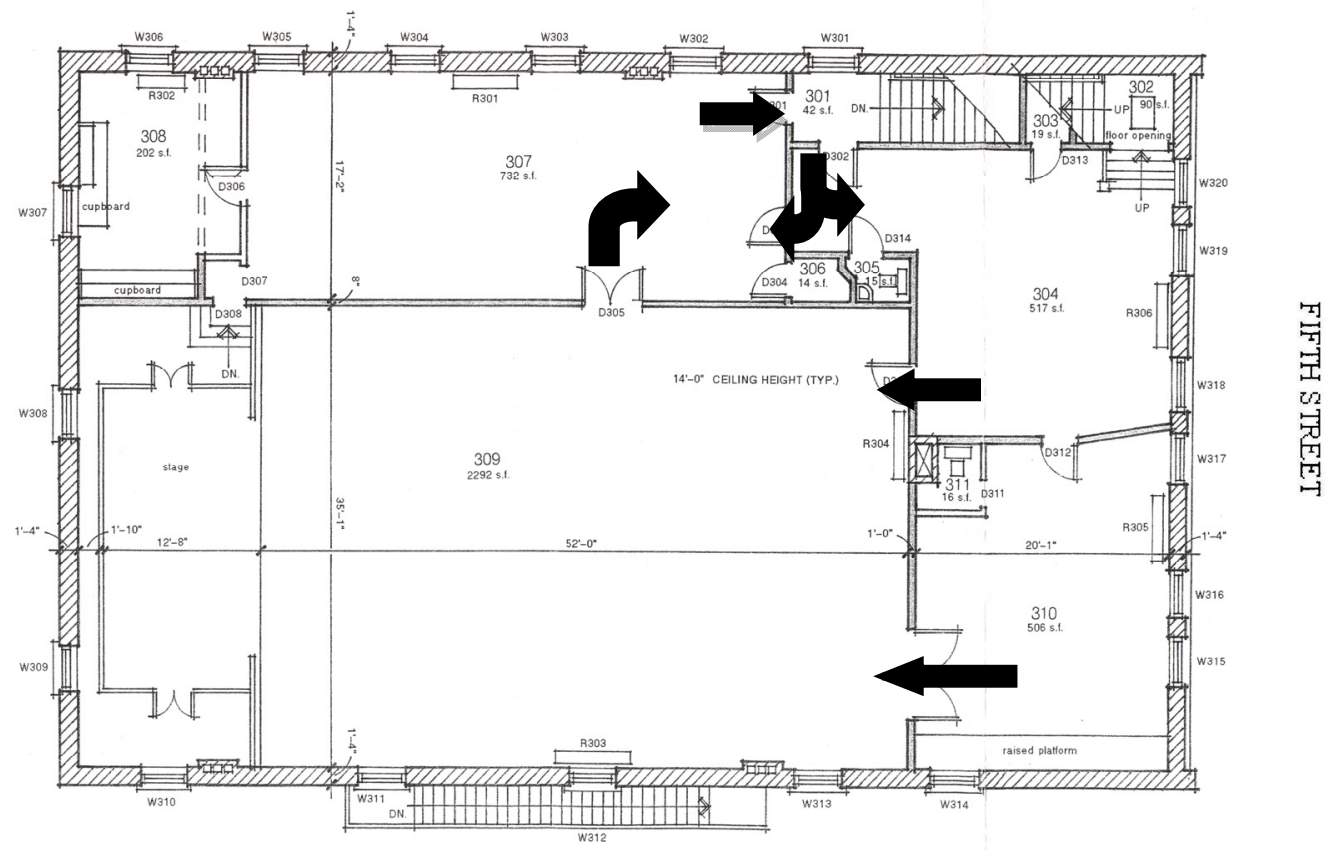

Figure 8.5: Ritual Use of the Union Building's Third Floor, modified from the Union Building Historic Structures Report. ${ }^{12}$ Arrows indicate movement taken by members, and bottom right shows the candidates entering through the candidates' door. 
Multiple distinct rituals "introduced new initiates to the fraternity's teachings and bolstered the belief systems of those enrolled. ${ }^{24}$ Candidates underwent a ritual at each step of his progression, ending with the third degree - Master Mason. Like Clifford Geertz's 'thick description,' the lodge hall is a "stratified hierarchy of meaningful structures [layers] are produced, perceived, and interpreted." ${ }^{25}$ The lodge hall enveloped meaning in the design of the structure through the Masons' use of the building within their ritualistic processions. In addition to providing meeting space the lodge shaped the ritual, from the procession of a new candidate to formal gatherings. In a way the Union Building served as an architectural anchor to their beliefs, to borrow from Max Weber it was a "web of significance he himself has [built]." The cultural atmosphere of the Masonic Lodge provided an interpretive approach to the meaning of the ritual. ${ }^{26}$

This atmosphere within the Masonic lodge was based around the construction of Solomon's Temple, echoing Masonic beliefs. Within the Lodge Masons "[assumed] the archetypical identity of "craftsman"” by separating themselves from the profane world outside. ${ }^{27}$ Kings Solomon, Hiram, King of Tyre, and Hiram Abiff represented the ideals the Masons were to emulate, and the kings became "living, breathing organisms each time the ceremony was performed." A solemn ceremony, the ritual took place in a private room, designed to house the performance. The performance was part symbolic drama, a "participatory theatre" and through the adoption of Christian elements in a

\footnotetext{
${ }^{24}$ Moore, Masonic Temples, 1.

${ }^{25}$ Max Webber, quoted in Bohannan, High Points in Anthropology, 534.

${ }^{26}$ Bohannan, High Points in Anthropology, 534.

${ }^{27}$ Moore, Masonic Temples, 2.
} 
consecrated place, as a "place of worship." ${ }^{, 28}$ This sentiment was seen in the Michigan Masonic Monitor, when "the officers and brothers of Lodge No .... are desirous that the Lodge should be duly consecrated, constituted, and dedicated...for which purpose they are now met in the Lodge room, by order of the Most Worshipful Master.” During the process of the consecration a ceremony began with a prayer asking the Great Architect of the Universe to "be with us now at our beginning." ${ }^{29}$ With the "corn of nourishment, the wine of refreshment, and the oil of joy" the hall underwent consecration into a proper Masonic Temple, an operating Lodge that transformed men into Masons. ${ }^{30}$

The hall served as both a location for ritualistic transformation as well as the pageantry. One of the most important aspects of the lodge hall is seen in the orientation of the ritual space and the lodge layout as seen in Figure 8.5. Within the lodge the

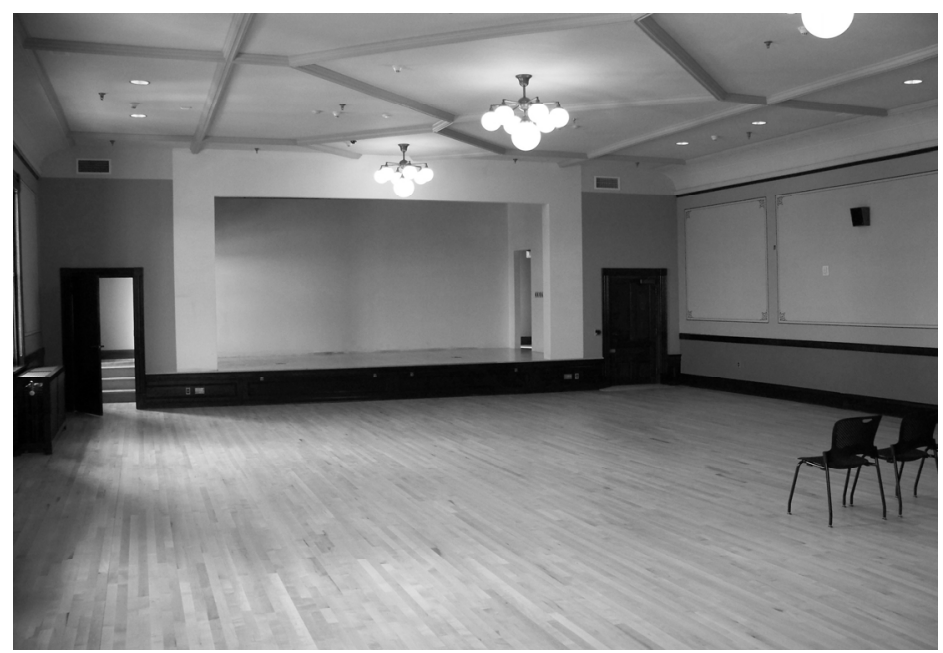

Figure 8.6: The third floor of the Union Building in Calumet today. This is after extensive rehabilitation to the room, although while similar it is not how it appeared historically. Compare to fig. 8.7 (Image by author)

\footnotetext{
${ }^{28}$ Moore, Masonic Temples, 14-16.

${ }^{29}$ Michigan Masonic Monitor, 33. This dedication ceremony was to follow the "ancient usages and customs of the Fraternity."

${ }^{30}$ Ibid, 34 .
} 
seating ensured that each individual "both saw and was seen by everyone" in an act of mutual observation. Through this observation the Masonic ritual and belief reinforced the group identity by providing a "concrete image of the brotherhood... and tightened the mystic tie that supposedly bound them together." In order to gain access to the sacred Masonic temple, the members had to climb two flights of stairs, passing the Independent Order of Odd Fellows Lodge No. 90 on the second floor, undergoing a liminal period that "separated the membership from pedestrian pursuits and prepared them for ritual activities." 31 Once the candidate reached the third floor, he went through an anteroom that prepared him for the ritual. Usually the candidate would be left alone, or with just one brother while the lodge prepared for his initiation. Within the Lodge Masons underwent "long periods of seclusion and training...rich in the deployment of symbolic forms." 32

Lodge halls typically lacked windows that would allow outsiders to observe the meeting. In an effort to maintain their secrecy the Masons usually used shutters, as used by Lodge 271, or in other cases decorative stained glass depicting Masonic lore. This decoration only added to the sense of the lodge as a spiritual space; even though "Freemasonry's status as a religious organization was hotly debated," the members identified the lodge room as sacred. ${ }^{33}$ The display of beauty and architecture also served to impress candidates with the agelessness of Masonry, as seen in Figure 8.7, with the painted scenery backdrops of the lodge. ${ }^{34}$

\footnotetext{
${ }^{31}$ Moore, 22-27.

${ }^{32}$ Turner, 41.

${ }^{33}$ Moore, 31.

34 "National Park Service, Keweenaw NHP"; Keweenaw Historic Photograph Collection; Newton, $50^{\text {th }}$ Anniversary Masons.
} 


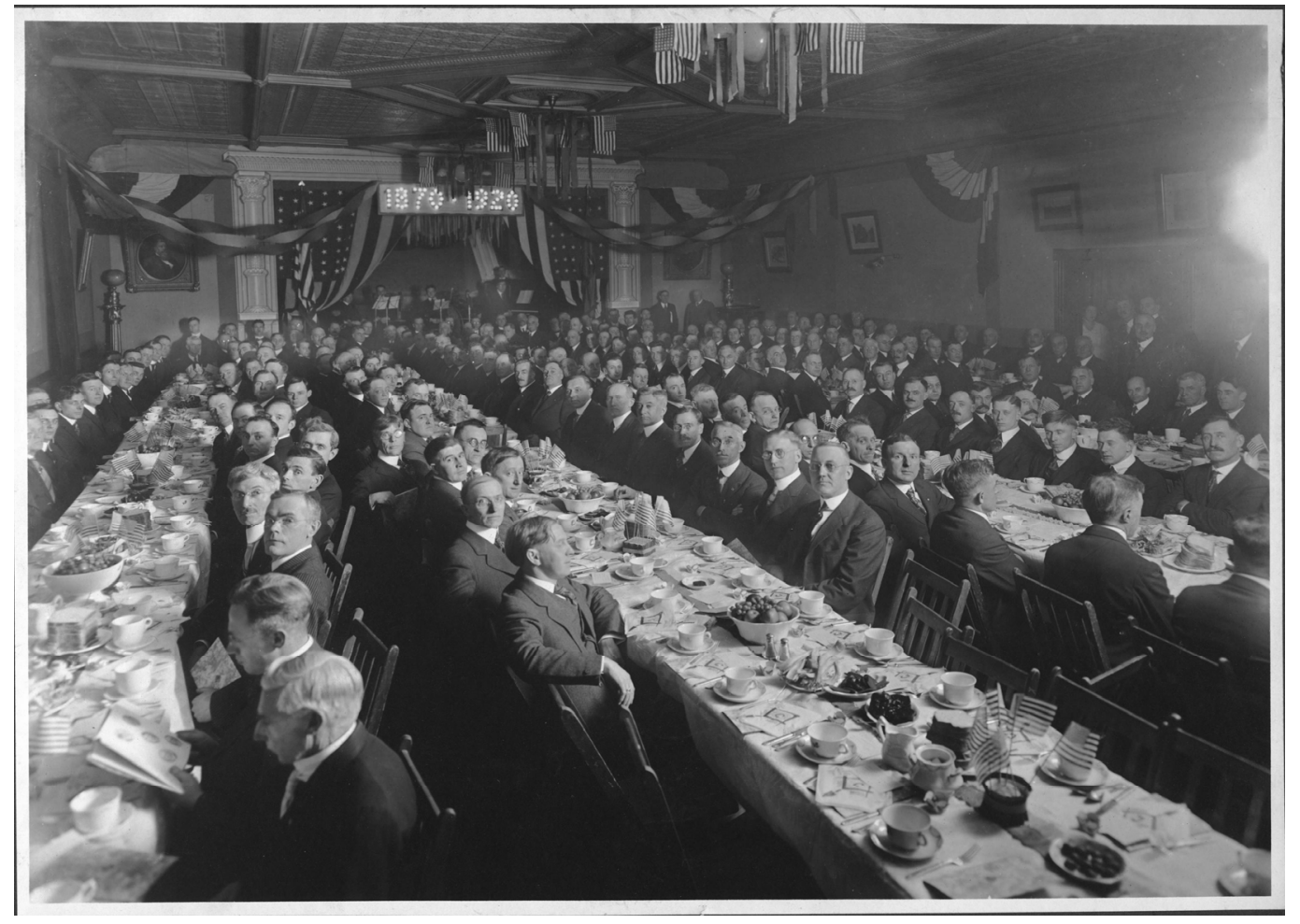

Figure 8.7: The third floor of the Union Building in use. Note the stage and scenery in the background as well as the pressed-tin ceiling. Figure from Masonic Lodge 271, $50^{\text {th }}$ Anniversary dinner of Lodge $271 .^{34}$

\section{Masonic Religion}

"Masonry is not a religion, yet it is religious," and it "rests upon the foundation of faith in the eternal God." "If there is a place on earth next to the church of God where reverence should be found and dignity should be observed, it is that place where a Masonic meeting is in session." 35 This meant that while Masonry did not serve the function of a church, it was interested in "directing the attention and concerns of its

\footnotetext{
${ }^{35}$ Henry W. Rugg, ed., The Freemason's repository (Providence,RI: E.L. Freeman \& Co, 1882-83),222. Moore, Masonic Temples, 33
} 
members towards spiritual considerations. ${ }^{, 36}$ Fraternal organizations clearly were not churches, "yet many of them have important rituals, ethical codes, and stands on public issues that are distinctly religious in flavor." ${ }^{, 37}$ As such the organization could be labeled a 'civil religion' - defined by Bellah in The Broken Covenant as a "common set of moral understandings" based on a "common set of religious understandings." ${ }^{38}$ When comparing the lodge space to a church or religious service, the behavior expected of Masons was "church etiquette." A member would "never...see the propriety of smoking in Lodge Rooms any more than in a church...to desecrate the Lodge-room is like desecrating the sanctuary of God itself., ${ }^{39}$ At the time Masonic rituals were codified, "toward the end of the nineteenth century Protestantism largely dominated American culture. ${ }^{\not 40}$ The comparisons to church behavior and the likeness between Masonry are seen not only in the attitude of members, but also in the lodge furnishings. ${ }^{41}$ The catalogues of S.C. Small \& Co supplied the same furniture to both groups. This reinforced the idea that while not a religion, the Masonic officers and Christian ministry "assumed equivalent forms" through the functional tie of furniture. ${ }^{42}$ Through their "religio-moral character" the Freemasons used the church as a framework to connect with the Protestant values to which a majority of the members then subscribed. ${ }^{43}$

\footnotetext{
${ }^{36}$ Dumenil, Freemasonry and American Culture, 48.

${ }^{37}$ Pamela Jolicoeur and Louis L. Knowles, "Fraternal Associations and Civil Religion," Review of Religious Research, vol. 20 (Fall 1978): 4.

${ }^{38}$ Robert Nelly Bellah, The Broken Covenant (Chicago: University of Chicago Press, 1984), ix.

39 “The Lodge Room," Masonic Standard 1, no. 16 (July 30, 1898): 4

${ }^{40}$ Dumenil, Freemasonry and American Culture, 46.

${ }^{41}$ Moore, Masonic Temples, 32.

${ }^{42}$ Ibid, 33.

${ }^{43}$ Jolicouer, "Fraternal Associations and Civil Religion," 6.
} 
Another important aspect of the Masonry that took place within the lodge ritual is the lodge room as a theatre. In this instance the lodge room served as both a "sacred space [but] also theatre in which participatory dramas were enacted." ${ }^{44}$ Part of the theatrical setting within the Union Building is the third floor stage, which "served to centralize and intensify focus on [the] ritual" with the "Revivalist design...concentrated on and around the stage. ${ }^{, 45}$ When the Union Building was constructed the third floor was an open space, as were most contemporaneous Masonic halls. However following the 1884 Scottish Rite Lodge in Chicago's relocation to the H.H Richardson's American Express building, and the 1893 Burnham and Root's Masonic Temple both of which had a stage "as well as a theatrical backdrops" Masonic halls underwent a redesign. ${ }^{46}$ (See Figure 8.7) These two structures ushered in a new era in lodge construction which affected the Kenwood Lodge No. 303 in Milwaukee, built in 1910. The lodge's architects, Leenhouts and Guthrie, designed "the lodge room to be

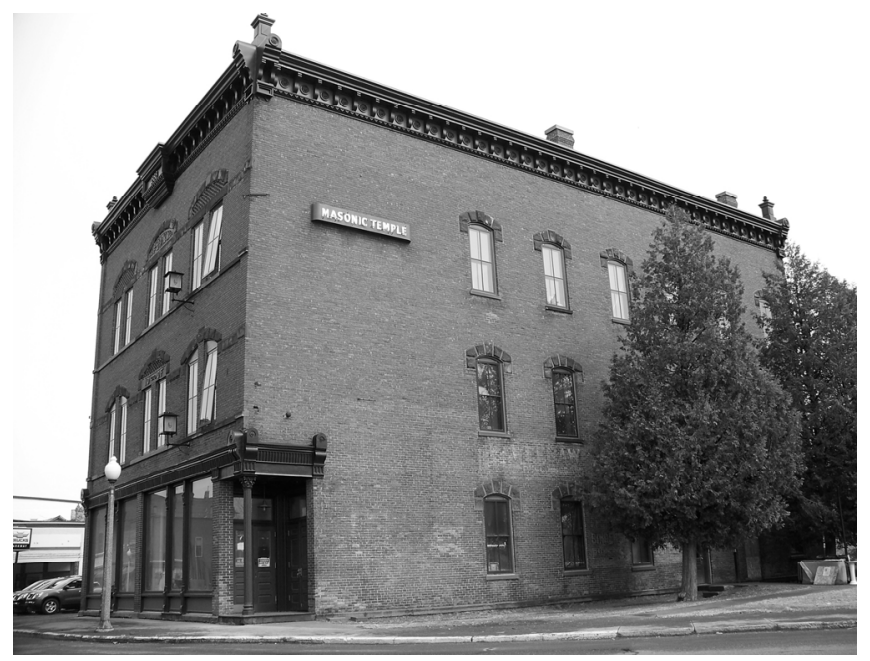

Figure 8.8, Exterior photograph of the Union Building taken in 2011 after undergoing exterior stabilization which preserved the historic structure. (Image by author)

\footnotetext{
${ }^{44}$ Moore, Masonic Temples, 34.

${ }^{45}$ Atwood, Historic Use of the Interior Space of the Union Building, 22.

${ }^{46}$ Ibid, 21.
} 
equipped with a stage," with stages becoming more the rule than an exception. The stage served to heighten the theatrical aspect of the Masonic Lodge, and this intensified focus on the Masonic ritual. ${ }^{47}$ (See Figure 8.7)

\section{Theatrical Masonry}

Despite the uniform ritual and ancient order the Freemasons added theatrics to "their rituals and made membership more appealing, so as not to lose members." One way to make the rituals more appealing was through the use of ceremonial clothing, which over time became more specialized into costumes. In the 1870s, the ritual "usually was performed in the member's business attire augmented by Masonic aprons, but by the 1890s lodges began to use costumes." ${ }^{48}$ In 1894 a commentator wrote "that the use of robes not only intensifie[d] the realistic part of the degree, but [was] more in keeping with the period which [they] intended to be portray." (Figure 8.9) The costumes "could be used as a crutch to assist brethren who were challenged by the presentation of the ritual." By the 1920s the market expanded beyond clothing to theatric backdrops

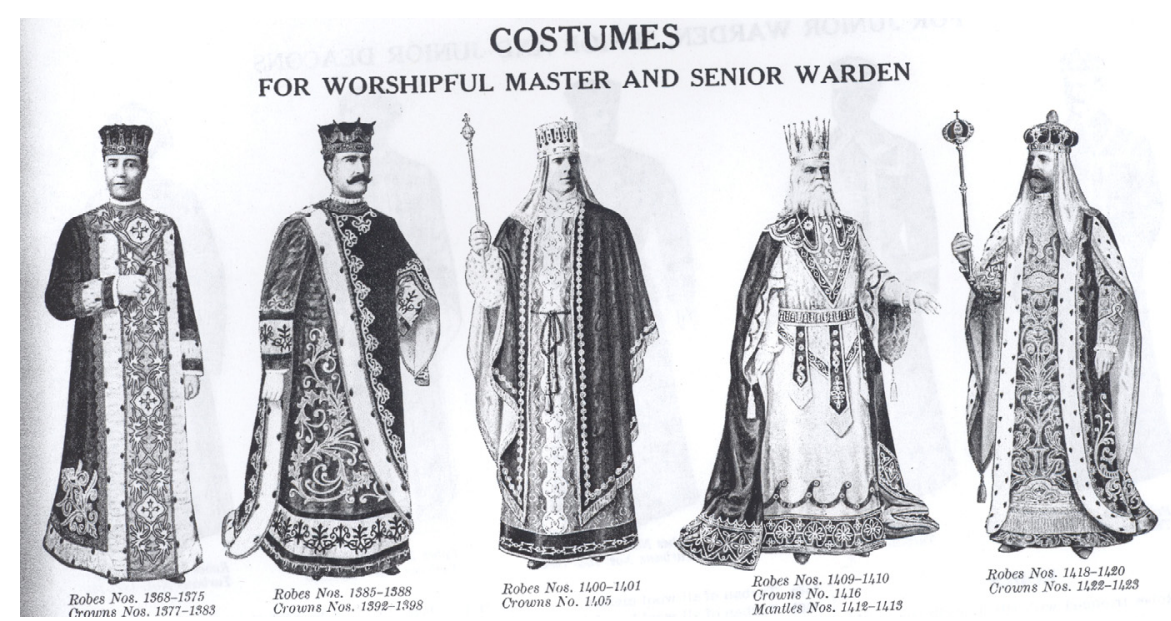

Figure 8.9: Masonic costumes worn during the rituals. Sold by the Henderson-Ames Company. ${ }^{52}$

${ }^{47}$ Atwood, Historic Use of the Interior Space of the Union Building, 21-22.

${ }^{48}$ McBride, "Fraternal Regalia in America, 1865-1918," ii.

and scenery. 
The purpose for all of the theatrical performances was to "assist American men in entering into a mythic alternative reality that transcended time and locality." ${ }^{49}$ This was done through a lodge layout where all rooms oriented east west, linking every lodge ideologically to each other. Within this space men who came from many backgrounds, occupations, and a spatially diverse area united in the goal of brotherhood within the lodge. As rooms dedicated to Masonic ritual, these rooms were considered sacred, with the activities inside "sanctioned by God, the "Great Architect of the Universe," leveling all members as craftsmen and uniting them all as Masons. ${ }^{50}$

The renewed focus on the theatre became clear when examining the "costumes, ritual articles of clothing...[that] were a singular and essential element" in the ritual. ${ }^{51}$ When combined with lighting such as the Henderson-Ames No. 1280,
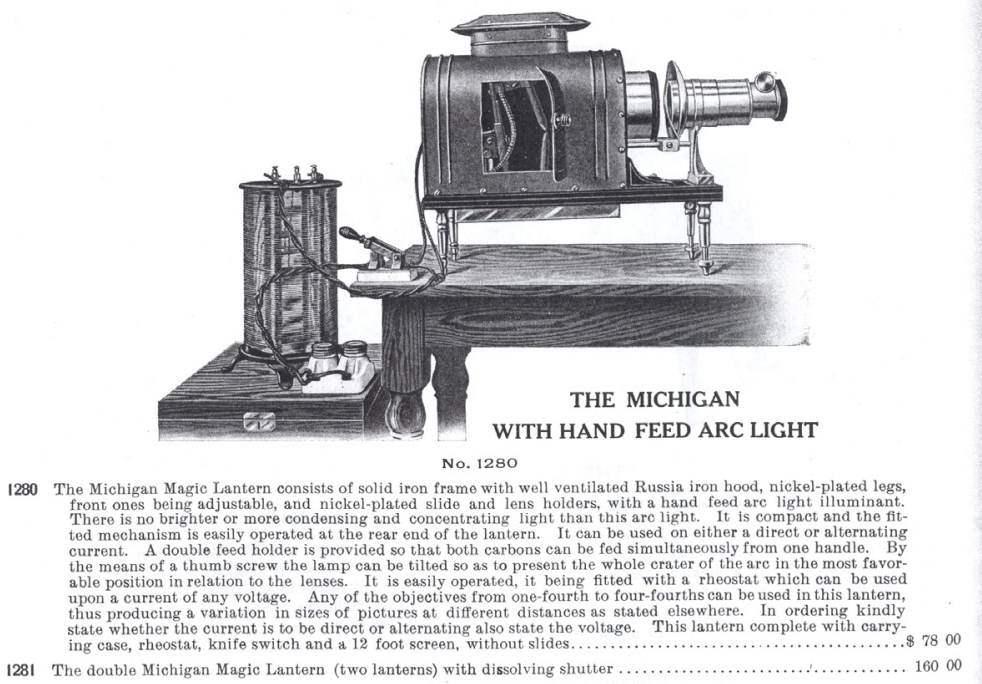

Figure 8.10: The Michigan with Hand Feed Arc Light. From The Henderson-Ames Company catalog, The Michigan with Hand Feed Arc Light. ${ }^{52}$

\footnotetext{
${ }^{49}$ McBride, "Fraternal Regalia in America, 1865-1918," 64.

${ }^{50}$ Moore, Masonic Temples, 36-39.

${ }^{51}$ McBride, "Fraternal Regalia in America, 1865-1918," ii.
} 
the Michigan with Hand Feed Arc Light, and thirty-eight-glass plate Masonic slides that could "easily be arranged by numbers before the lectures" to provide a dramatic backdrop. (Figure 8.10$)^{52}$

While the fraternal orders used theatrics within the realm of public display picnics, parades, and gatherings - the focus was on the leveling process of the Masonic rites. As Edwin Booth, actor and nineteenth-century member wrote - "to be a Worshipful Master, and to throw my whole soul into that work, with the candidate for my audience and the Lodge for my stage" the evenings were a sort of community theatre in which "Masons entertained themselves." ${ }^{\text {" T3 }}$ The concept of the lodge room as a theatre did nothing to "dilute its identity as a sacred space" as the "theatre and church were compatible concepts" in American life. If anything the theatre, with "ancient legends, historical incidents [and] regalia provid[ed] fantasy and drama," reinforced the ritual by engaging the members. This allowed Masons to relive the dramatic basis for their order. ${ }^{54}$ During the ritual practice that Edwin Booth described, the Worshipful Master played the role of King Solomon, while the Senior Warden portrayed Hiram, King of Tyre. The ritual had "participatory enactments structured around memorized dialogue and standardized floor movements" performed on the lodge floor between the seats and the altar. ${ }^{55}$ The rest of the lodge wore an apron that signified "their status as workmen involved in the construction of Solomon's temple" - of which the HendersonAmes Company sold seventy-two different styles. ${ }^{56}$ These aprons ranged in price from

\footnotetext{
${ }^{52}$ The Henderson-Ames Company, 92-97

${ }^{53}$ Moore, Masonic Temples, 34.

${ }_{55}^{54}$ McBride, "Fraternal Regalia in America, 1865-1918," 170.

${ }_{55}^{55}$ Moore, Masonic Temples, 35.

${ }^{56}$ Ibid, 35, Henderson-Ames, 3-7.
} 
$\$ 1.50$ to $\$ 8.00$; this allowed all Masons, regardless of income, to have acceptable garb to wear during the ceremony. Having undergone the act of leveling within the lodge, the candidates would not have been expected to know their lines to the ritualistic responses. Due to this, within the unfolding drama, the initiates "were assigned a guide or spokesman who responded for them when they were challenged within the ritual" regarding their worthiness for Masonic membership. ${ }^{57}$

The lodge likely provided the costumes for the main participants in the ritual, down to the slippers required of the Entered Apprentice and Fellowcraft degrees. Also each participating officer "was required to memorize the portions of the ritual that he was responsible for presenting." As a member progressed through the Lodge offices he "committed to memory increasingly larger portions of the text;" by the time a member became the Worshipful Master he had "memorized the entire text." Memorizing his lines not only aided in the dramatic effect of the rituals but also helped members to “internalize the fraternity's lessons concerning loyalty, cooperation, and authorityWithin the ritual the Worshipful Master had a commanding role, wearing a crown and robe and holding a scepter. Ranging from the robe "full lined, front of satin, elaborately silk embroidered" of a wool merino for $\$ 22$, to a "robe of best quality silk plush...lined with satin... all trimmed with heavy laces, fringe and tassels" for $\$ 144$, plus crowns ranging from $\$ 6.15$ to $\$ 20$, the Henderson-Ames Company and others like it offered a wide price-point variation. ${ }^{58}$ These theatrical performances took place within the lodge room, aided by the costumes and makeup that "added theatrical

\footnotetext{
${ }^{57}$ Moore, Masonic Temples, 35.

${ }^{58}$ Henderson-Ames, 95.
} 
spectacle to the ritual's words.",59

${ }^{59}$ Moore, Masonic Temples, 36. 


\section{Chapter 9: Masonic Items}

\section{Badges of Brotherhood}

The only regalia that lodge members were required to purchase was "the badge of

Freemason - a white lambskin apron."” (See Figures 9.1 and 9.2 for multiple styles of Masonic aprons $)^{2}$

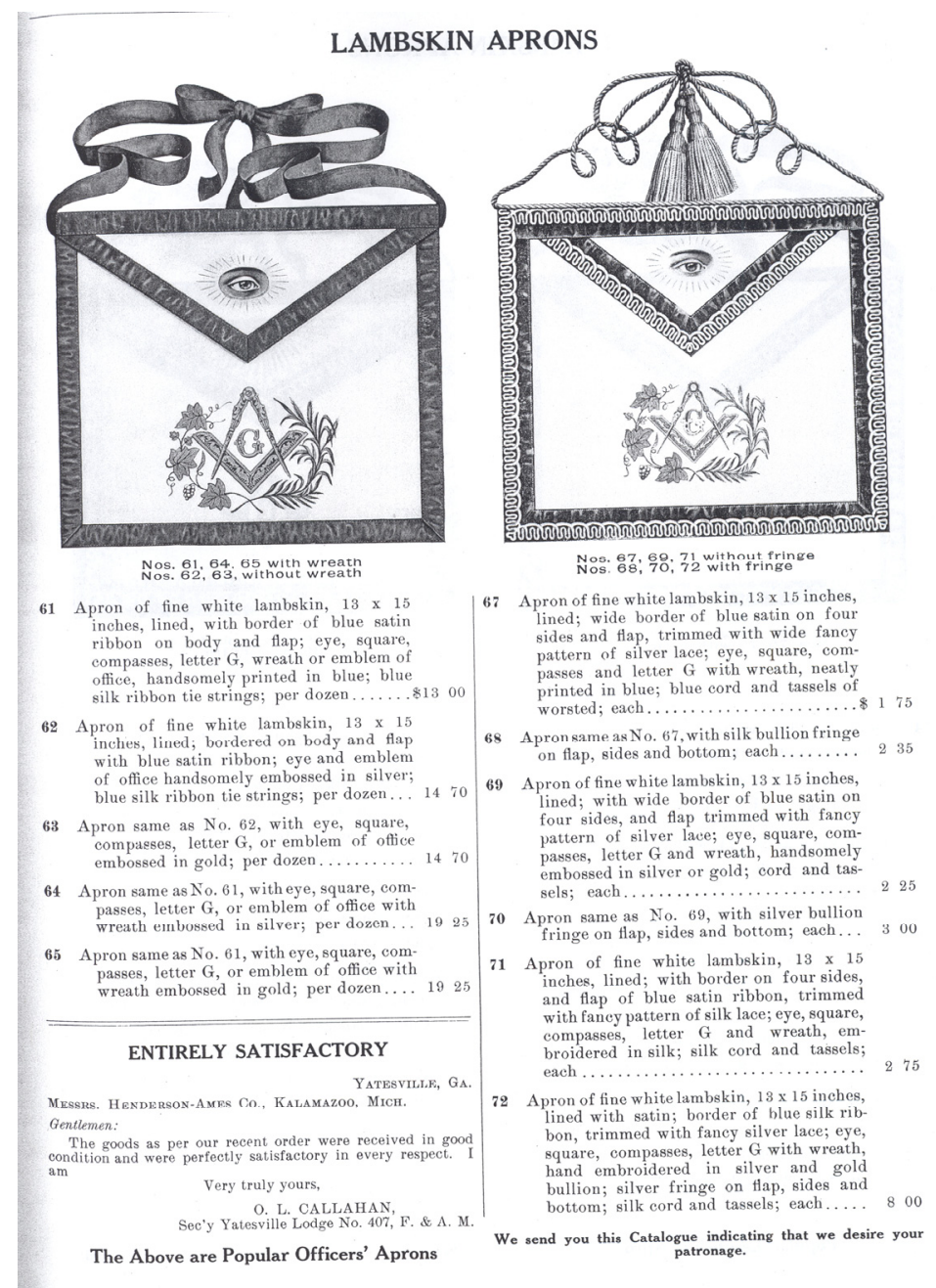

Figure 9.1: Masonic Lambskin Aprons. From The Henderson-Ames Company, Lambskin Aprons. ${ }^{2}$

\footnotetext{
${ }^{1}$ McBride, "Fraternal Regalia in America, 1865-1918," 212.

${ }^{2}$ The Henderson-Ames Company, 7-8.
} 

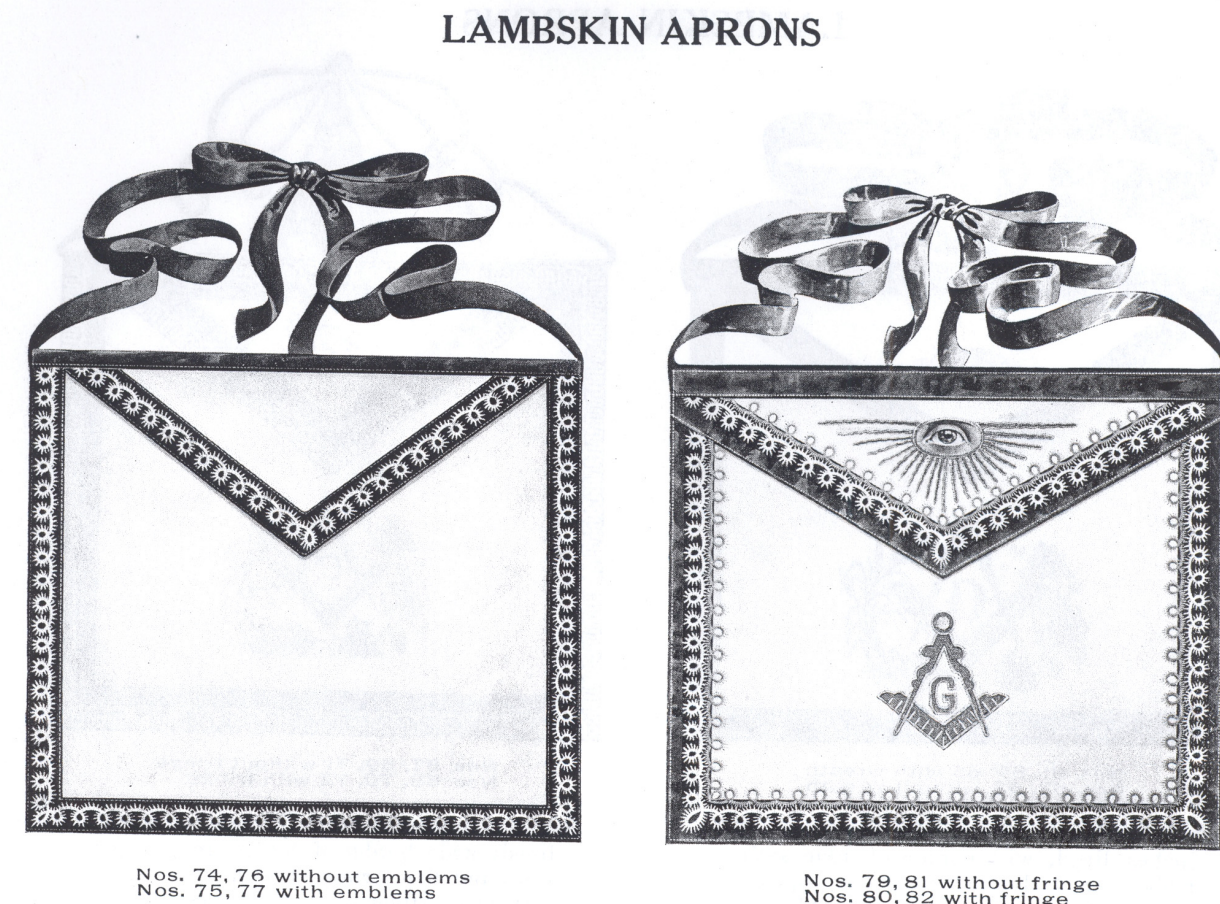

Nos. 79,81 without fringe
Nos. 80,82 with fringe

74 Apron of fine white lambskin, $13 \times 15$ inches, lined; with border of blue satin, handsomely silk embroidered; blue satin tie strings; each $\$ 1.20$; per dozen.....\$13 85

75 Apron same as No. 74, with eye on flap and emblem of office silk embroidered on body; each $\$ 1.70$; per dozen......... 2025

76 Apron of fine white lambskin, $13 \times 15$ inches, lined; with border of blue silk ribbon on body and flap handsomely silk embroidered; eye, square, compasses and letter G' printed in blue; blue silk ribbon tie strings; each $\$ 1.25$; per dozen..... 1450

77 Apron same as No. 76, with eye on flap and emblem of office on body of apron embossed in gold; blue silk ribbon tie strings; each $\$ 1.50$; per dozen....... 1800

Popular Lambskin Aprons
79 Apron of fine white lambskin, $13 \times 15$ inches, lined; with border of blue satin, all richly silk embroidered as illustrated; eye, square, compasses and letter $G$, embroidered in silk; blue silk ribbon tie strings; each $\$ 2.50$; per dozen .......\$29 50

80 Apron, same as No. 79, with blue silk bullion fringe on flap, sides and bottom; each $\$ 3.20$; per dozen ............ 3880

81 Apron of fine white lambskin, $13 \times 15$ inches, lined; with border of blue silk velvet, handsomely silk embroidered as illustrated; eye, square, compasses and letter $\mathrm{G}$, embroidered by hand in silver bullion; each $\$ 3.65$; per dozen.... 4375

82 Apron same as No. 81, with silver bullion fringe on flap, sides and bottom; each $\$ 4.05$; per dozen ................ $48 \quad 25$

We guarantee our goods to be Exactly as Represented

Figure 9.2: More Variations in the Aprons, note the prices (some are sold by the dozen). Figure is from the Henderson-Ames Company, Lambskin Aprons. ${ }^{2}$ 
As the fraternal movement grew in both size and scope of membership increasingly more complex items were offered for purchase. After 1870 nothing was plain in Masonic regalia. ${ }^{3}$ This is evident in the items used by lodges like Masonic Lodge 271, and photographs such as figure 8.7 with its painted backdrops and ritual decoration. As an expression for the Masonic penchant for theatre, even their Lodge hall had a set of lights to illuminate the stage during their rituals including Lodge 271 . Ideally one could trace the lodge purchases of ritual attire, or lodge member's accounts of items worn during ceremonies, parades, or over the course of lodge night. Unfortunatly surviving records and Masonic ritual items do not document entirely which Masonic visual items were in the Calumet Lodge.

Much like the ritual brought men from the profane world into the Masonic reality that transcended time and space, Masonic jewels and symbols underwent a similar transformation. To outsiders the Masonic aprons might have value as assigned by the catalogs, or perhaps an emotional attachment from a family member who belonged to the lodge. Masons however saw them as more than a commodity - they were part of the Masonic moral economy. ${ }^{4}$ One can not know a Masonic symbol if he does not recognize Masonic symbols; one has to be a Mason to understand the deeper meaningh behind the items. Only Masons could understand the moral economy "that stood behind the objective economy." Working tools occupied a singular niche in Masonic symbolism. Because of this the items "[became] less of a commodity and more of a

\footnotetext{
${ }^{3}$ McBride, "Fraternal Regalia in America, 1865-1918," 213.

${ }^{4}$ The items were "culturally marked" through Masonic thought to have a symbolic value. Through the Masonic transformation the items acquired new statuses known only to Masons. Igor Kopytoff, Interpretive Archaeology (Leicester: Leicester UP, 2000), 64.

${ }^{5}$ Ibid 64.
} 
singular" object through the added layers of Masonic meaning. ${ }^{6}$ The ritual itself provided the context through which the items "can be intelligibly, that is, thickly described" to fellow Masons. ${ }^{7}$

\section{Threshold Values}

When looking at Masonic items, as Igor Kopytoff in Interpretive Archaeology noted with symbolic items in general, one must look at the "biographical possibilities inherent in its "status'."8 Through the Henderson-Ames Company catalog Kopytoff can be applied to Masonry, the initial monetary value of the items can be determined, but this does little to provide the societal values attached to them. This is part of the culturally constructed value, "endowed with culturally specific meanings and classified and reclassified into culturally constituted categories." "9 It may not be possible for a nonMason to understand the symbolism behind a setting maul; the symbolic items are more seen as a commodity. The fact that the Masonic items are "unique and unexchangeable...uncommon [and] incomparable" makes them singular to the lodge even though they were "saleable or widely exchangeable" through catalogs, including

Sears-Roebuck \& Co. ${ }^{10}$ As such the common items attained singular value for members of the Lodge. The supply catalogs therefore commoditized Masonic items but not the meaning behind them. While Kopytoff noted "in no system is everything so singular as to preclude even the hint of exchange," the singular value attached by the Lodge made

\footnotetext{
${ }^{6}$ Kopytoff, Interpretive Archaeology, 65.

${ }^{7}$ Geetz, quoted in Bohannan, High Points in Anthropology, 539.

${ }^{8}$ Kopytoff, Interpretive Archaeology, 66.

${ }^{9}$ Ibid, 68.

${ }^{10}$ Ibid, 69 .
} 
that unlikely. ${ }^{11} \mathrm{He}$ also stated "there are things that are publicly precluded from being commoditized... as the symbolic inventory of a society [including] ritual objects." 12 The very fact that the items were sold in catalogs contradicts this to some extent however, as more people could easily purchase them; once purchased they were unlikely to part with them. They underwent a "restricted commoditization, in which some things are confined to a very narrow sphere of exchange;" as mentioned earlier the wide range in prices allowed all the members basic access to this sphere. ${ }^{13}$ Only Masons had access to the "ideological symbols upon which [they] were based," and the material culture of Masonry was key to their ritual and belief structure; "ritual and regalia used to distinguish insiders from outsiders... to distinguish degrees or levels"14 These items, after undergoing singularization by the group "[bore] the collective stamp of approval" and they take "on the weight of cultural sacredness."15 Thus the material culture of Masonry was used to "create and preserve a collective identity."16

\footnotetext{
${ }^{11}$ Kopytoff, Interpretive Archaeology, 70-73.

${ }^{12}$ Ibid, 73 .

${ }^{13}$ Ibid, 77.

${ }^{14}$ Bohannan, High points in Anthropology, 541.

${ }^{15}$ Kopytoff, Interpretive Archaeology, 81.

${ }^{16}$ Morgan Hermanowicz and Harriet P. Morgan, "Ritualizing the Routine: Collective Identity Affirmation,” Sociological Forum, 14, no. 2 (June 1999): 197.
} 


\section{Chapter 10: Conclusion}

\section{Lodge Diversity}

Kopytoff noted that individuals undergoing a ritual transformation were "stripped of [their] previous social identity and [became] a non-person" until reborn. This took place within the lodge with the initiate's obtainment of the Master Mason degree. ${ }^{1}$ The Lodge organized myriad individuals into a single entity, with "the organizational capacity to act in its own behalf." 2 Men from most walks of life joined the Masonic brotherhood in Calumet. With a majority of Calumet's population foreign-born the lodge may have offered a community for new male immigrants. In 1900 fifty-four percent of the lodge membership was born abroad, with Scottish and English, the predominate nationalities or born in the United States to foreign-born parents. The Scots composed twelve percent of the Lodge, and English another twenty-five percent while Americans were only six percent of the membership. ${ }^{3}$ Americans are defined as having both parents born in the United States. Compared to the overall percentage of English and Scottish residents of Calumet, at eleven and two percent, these ethnicities were overrepresented in the Masonic Lodge. ${ }^{4}$

This reinforces Dumenil's claim that the lodge was "more receptive to immigrants" and in large urban areas Masonic immigrants "gathered in distinct ethnic lodges," conducting ritual and business "in their own native tongue." It is important to

\footnotetext{
${ }^{1}$ Kopytoff, Interpretive Archaeology, 378.

${ }^{2}$ Clawson, "Fraternal Orders and Class Formation," 676.

${ }^{3}$ U.S. Census of Population and Housing, 1900, 1901.

${ }^{4}$ Anna Brock, Chelsea Cole, et. all, "Diversity in Calumet, Michigan, 1910." (HST 333H, Central Michigan University, 2005), 15.

${ }^{5}$ Dumenil, Freemasonry and American Culture, 10.
} 
note the nationality is not known for forty percent of the members in Calumet, because they did not turn up in the Houghton County census for that year. While one may not be able to know for sure, it is also likely that a significant percentage of those without nationalities were also recent immigrants. This could increase the foreign component of Lodge 271 to upwards of seventy percent.

Table 10.1

Ethnic Groups within Red Jacket c. 1900

\begin{tabular}{|l|c|c|}
\hline \multicolumn{1}{|c|}{ Ethnicity } & Amount & Percentage \\
\hline America & 23 & $5 \%$ \\
\hline Croatian & 73 & $15 \%$ \\
\hline English & 52 & $11 \%$ \\
\hline French-Canadian & 15 & $3 \%$ \\
\hline Finnish & 76 & $16 \%$ \\
\hline German & 61 & $13 \%$ \\
\hline Irish & 14 & $3 \%$ \\
\hline Italian & 38 & $8 \%$ \\
\hline Jewish & 10 & $2 \%$ \\
\hline Norwegian & 19 & $4 \%$ \\
\hline Polish & 11 & $2 \%$ \\
\hline Slovenian & 28 & $6 \%$ \\
\hline Swedish & 22 & $5 \%$ \\
\hline Total & 472 & $\approx 100 \%$ \\
\hline
\end{tabular}

Looking at Table 10.1 provides a breakdown of the ethnic groups that called the Village of Calumet home. This was taken from a study of 494 households from the 1900 U.S. Census in which the ethnic origins of the residents were sorted by ethnic heritage. ${ }^{6}$ Within this study only 472 of those households were studied, ethnic groups with less than $2 \%$ of the population were discarded. Interestingly enough this excludes the Scottish as they only composed $1.6 \%$ of the households. One limitation of this study is its sole focus on the village of Calumet, excluding Calumet Township, Laurium, and

\footnotetext{
${ }^{6}$ Brock, "Diversity in Calumet," 7.
} 
the surrounding area where numerous Masons lived. Compared to the larger population of the vicinity, the Lodge was overwhelmingly from the British Isles over representing those nationalities in the Lodge by a factor of two or three. This reinforces that Lodge 271 was not a representative sample of the larger multiethnic population.

\section{Class and Membership}

The primary question that this study sought to answer was the influence of class on Masonic membership within Lodge 271. There is a chance that local lodges "may have been almost exclusively white-collar or blue-collar" when compared to the national trend that was oriented towards a more elite membership. Without comparative roles from contemporaneous Masonic Lodges in other locations it is not possible to draw a concrete conclusion. ${ }^{7}$ With Clawson's use of the terms working class and blue collar as synonymous, her percentages of membership that fall within each category provided different results than membership distribution of Calumet's lodge. It is likely though that few American fraternal orders were class homogenous and "mixed-class membership was to be found among a substantial number of local lodges." ${ }^{8}$ While in general Masonic lodges had a more elite membership than other fraternal groups such as the Odd Fellows or Foresters, this was not the case with Calumet's lodge. If anything the lodge maintained its orientation towards working and middle-class membership between 1900 and 1920, with combined working and middle-class membership at about fifty-eight percent over the twenty-year study period.

While all members of the Lodge were "brothers upon the same level" the ritual

\footnotetext{
${ }^{7}$ Clawson, Construting Brotherhood, 98.

${ }^{8}$ Clawson, Construting Brotherhood, 106
} 
"established a hierarchy among members...hinting at a paternal role for the Worshipful Master and Senior Wardens." ${ }^{\prime 9}$ They were expected to raise the new members into full Masonic membership, presiding over the lodge like "the head of a family." ${ }^{10}$ However both Calumet's Senior Warden and Worshipful Master were not exclusively upper class, giving evidence of working class participation within the Lodge. The lodge officer's class composition echoed the general lodge, in that men of all classes gained an office. In 1900 the Worshipful Master was William Phillips, a shop foreman and middle class member. The Senior Warden - Lucius W. Killmar, a bookkeeper and the Secretary - James W. Merton, a draftsman at Calumet and Hecla belonged to the working class. George Unsworth the Tyler respectably was an upper middle class member, working as an engineer. By 1910 the officer composition had changed slightly. E.L. Thomas and Josiah Harper served Senior Deacon and Junior Warden respectively; both were employed as clerks and belonged to the working class. The other six officers ranged in employment from Charles Noetzel as Chief Clerk of the Wolverine Copper Mining Co. to George Williams, the Freight and Passenger Agent of the Mineral Range Railroad - both upper middle class occupations. ${ }^{11}$ From 1900 to 1920 the percentage of the officers from the lower class declined, while the middle and upper middle classes gained a higher amount of offices when compared to general lodge membership. It is surprising however that multiple officers were counted as working or middle class.

Within Lodge 271 all members had a chance to guide the lodge when elected as Worship Mastetr. Due to Masonry acting as a moral guidebook, Masons were instructed

\footnotetext{
${ }^{9}$ Carnes, Secret Ritual and Manhood, 120.

${ }^{10} \mathrm{Ibid}, 121$.

11 “Annual Returns of Calumet Lodge 271, 1900-1920"
} 
to provide aid to brothers in need. It is highly likely that they treated other members as equals. In fact there are Masonic stories that tell of a man in need, and upon his identity as a Mason becoming known other Masons extended a helping hand. So in a society where divisions between social classes were by and large an accepted fact the Masons provided a liminal or transitional setting where those divisions were less important. At the same time the divisions, while not apparent between brothers, could be seen based on the attire a member purchased for use within the lodge, and what (if any) pins, rings, or badges they wore outside the lodge to designate themselves as Masons. It seems the case in Lodge 271 that the civic life offered by the Masons brought about social engagement, as seen by the cross-class membership, and also class "de-formation" through the ritual transformation and elevation to Master Mason. ${ }^{12}$

The Masons allowed "workers, clerks, businessmen, and professionals...fellowship that to a greater or lesser extent modified, ignored, or even repudiated the boundaries of class," as exemplified within Lodge $271 .{ }^{13}$ This also conflicts with the idea of Masonic membership as expressed by Blumin in The Emergence of the Middle Class. Blumin stated that the Freemasons "generally associated with the more prosperous and influential sectors of the community." ${ }^{\prime 4}$ This may have been a reason the working class joined the lodge, as a means of social advancement. With Blumin's study lodge of thirty-eight, only one member was a clerk while seventeen were merchants and manufacturers. ${ }^{15}$ With the variation between

\footnotetext{
${ }^{12}$ David Lockwood, "Civic Integration and Class Formation", The British Journal of Sociology, 47, no. 3 (September 1996): 532.

${ }^{13}$ Blumin, The Emergence of the Middle Class, 218.

${ }^{14}$ Ibid, 226.

${ }^{15}$ Ibid, 226.
} 
lodges it is likely that even local lodges such as Houghton drew a higher proportion of its membership from higher economic groups. This would require further examination of the ledgers to see if the high percentage of working and middle-class membership carried over to neighboring mining communities with a constant flux of immigrants.

\section{Further Study}

It is important to note that there are some shortcomings with the method employed in this study which I have assigned the members of the lodge to various economic classes. To what extent the identified groups had a sense of classconsciousness is difficult to determine with the information on hand. Class consciousness "[does not] derive automatically from economic and social conditions" but with the information available for this study occupation and indirectly economic conditions was the most reliable source for determining classes within the Masonic Lodge. ${ }^{16}$ Class is problematic in trying to understand the social relations of individuals within a society that ceased to exist decades ago. While there are descendent groups in the community that claim the Masonic heritage, they are not the same men who joined the lodge in 1900. The classes used for this discussion are static and defined on paper, and "classes on paper are not necessarily classes in society." ${ }^{17}$ E.P. Thompson noted that "the notion of class entails the notion of historical relationship" and such a relationship was constantly fluid and "evades analysis if we attempt to stop it dead" and define it. ${ }^{18}$ Even though the groups may have occupied a similar economic setting, lived in the same area, and even attended the same church does not mean they were aware of

\footnotetext{
${ }^{16}$ August, The British Working Class, 2.

${ }^{17}$ Levin, Bringing Class Back In, 103.

18 Thompson, The making of the English working class, 9.
} 
or thought of themselves as belonging to one homogeneous class. ${ }^{19}$ Also due to internal divisions between levels of skill within an occupation, grouping an occupation into a class based on that occupation could be problematic. One more limitation with this study was the reliance on economic studies published multiple decades after the period of study. Even though the idea of class was examined in 1900 and 1920, the 1975 study provides a broader sample and more detailed study on occupation and its link to economic class. In 1975 the country surveyed still had a high percentage of individuals employed in manual labor that can be associated with working class occupations.

Through this examination it can be determined that Lodge 271 did have a significant working and middle-class membership, higher than lodges studied by De Los Reyes and Clawson. This could be the result of a highly mobile population that placed a high value on the social status and attainment the lodge may have offered. Within the larger community Lodge's 271 membership was spatially diverse with little class divisions expressed geospatially, with random distribution of members indicating poorly defined economic enclaves in the community. The Masonic ritual allowed all successful applicants to seek moral refinement. This refinement insured all men who applied would be treated as equals, and they would not be rejected out of prejudice but due to un-Masonic qualities. For members that wanted to display their status, Henderson-Ames objects allowed them to do so. However within the lodge men from all social backgrounds passed through the ritual transformation, underwent the act of leveling, and emerged as "brethren upon the same level."

\footnotetext{
${ }^{19}$ Levin, Bringing Class Back In, 104.
} 


\section{Bibliography}

\section{Books}

Addison, Charles G. The History of the Knights Templars. 1842. Reprint, Kempton, Ill.: Adventures Press Unlimited, 1997.

Alexander, Bobby C. Victor Turner Revisited. Atlanta: Scholars Press, 1991.

Anderson, James The Constitution of the Free-Mason. Containing the History, Charges, Regulations, etc. Philadelphia, 1734.

An Interior Ellis Island, MTA \&CCHC, http://ethnicity.lib.mtu.edu/intro.html.

Atwood, Stephanie K. Historic Use of the Interior Space of the Union Building. Calumet, MI: Keweenaw National Historical Park, 2008.

Andrew August, The British Working Class: 1832-1940. New York: Pearson Longman, 2007.

Baritz, Loren, The Good Life: The Meaning of Success for the American Middle Class. New York: Perennial Library, 1989.

Beito, David T., From Mutual Aid to the Welfare State. Chapel Hill: University of North Carolina Press, 1999.

Bellah, Robert Nelly, The Broken Covenant. Chicago: University of Chicago Press, 1984.

Bennett, John R. The Origin of Freemasonry and the Knights Templar. 1907, Reprint, Whitefish, MT: Kessinger Publishing, 2010.

Bohannan II, Paul and Galzer, Mark, eds. High Points in Anthropology. New York: McGraw-Hill, 1988.

Brock, Anna, and Cole, Chelsea, et. all, "Diversity in Calumet, Michigan, 1910." HST 333H, Central Michigan University, 2005.

Blumin, Stuart, The Emergence of the Middle Class: Social Experience in the American City, 1760-1900. New York: Cambridge UP, 1989.

Carnes, Mark C., Secret Ritual and Manhood in Victorian America. New Haven, CT: Yale UP, 1989. 
Clawson, Mary Ann, Constructing Brotherhood: Class, Gender, and Fraternalism. Princeton, NJ: Princeton UP, 1989.

Conover, Jefferson S., Freemasonry in Michigan. Coldwater, MI: Conover Engraving and Printing Company, 1884.

Drew, William H., The Freemason's Hand-Book: Containing the Ritual of Freemasonry. New York: Macoy and Sickles, 1860.

Dumenil, Lynn, Freemasonry and American Culture. Princeton, NJ: Princeton UP, 1984.

Duncan, Malcolm C. Duncan's Ritual and Monitor of Freemasonry. New York: Dick \& Fitzgerald, 1866.

Eichar, Douglas M., Occupation and Class Consciousness in America. Santa Barbara,CA: Greenwood Press, 1989.

Ferguson, Charles W., Fifty Million Brothers: A Panorama of American Lodges and Clubs. New York: Farrar \& Rhinehard, Inc, 1937.

Gates, William, Michigan Copper and Boston Dollars: An Economic History of the Michigan Copper Mining Industry. Cambridge: Harvard UP, 1951.

Gilbert, Dennis, The American Class Structure in an Age of Growing Inequality. Newbury Park,CA: Pine Forge Press, 1998.

Gould, James L., Guide to the Royal Arch Chapter: A complete monitor for Royal Arch Masonry. New York: Macoy, 1886.

Hamilton, John D., Material Culture of the American Freemason. Lexington: National Heritage Museum, 1994.

The Henderson-Ames Company, Manufacturers of Masonic Lodge Supplies. Kalamazoo, MI: The Henderson-Ames Co. 1902.

Hoagland, Alison K., Mine Towns: Buildings for workers in Michigan's Copper Country. Minneapolis: University of Minnesota Press, 2010.

Hollands, William C., The Eastern Star of Michigan, 1855-1942. Ann Arbor, MI: Edwards Brothers, Inc., 1942.

Katz, Jacob, "The Fight for Admission to Masonic Lodges," Leo Baeck Institute Yearbook, vol. 11, no 1 (2000).

Kopytoff, Igor, Interpretive Archaeology. Leicester: Leicester UP, 2000. 
Keweenaw National Historical Park, Downtown Calumet: Guide to the historic mining community. Hancock, MI: Book Concern Printers, 2006.

Lankton, Larry, Cradle to Grave : Life, Work, and Death at the Lake Superior Copper Mines. New York: Oxford UP, 1993.

Lankton, Larry, Hollowed Ground: Copper Mining and Community Building on Lake Superior, 1840s-1990s. Detroit: Wayne State UP, 2010.

Levine, Rhonda R. and McNall, Scott G., Bringing Class Back In: Contemporary and Historical Perspectives. Greely, CO: Westview Printing and Graphics, 1991.

Mackay, Albert G., Manual of the Lodge. New York: Maynard, Merrill, \& Co, 1898.

Macoy, Robert, Manual of the Order of the Eastern Star. New York: Masonic Publishing and Manufacturing Co, 1865.

Malinowski, Bronislaw and Redfield, Robert, Magic, Science and Religion and Other Essays. 1954. Reprint, Whitefish,MT: Kessinger Publishing, 2004.

McBride, Harriet W., "Fraternal Regalia in America, 1865-1918: Dressing the Lodges, Clothing the Brotherhood." Ph.D. diss, Ohio State University, 2000.

Michigan Masonic Monitor. Detroit: The Grand Lodge of Michigan, 1897.

Moore, William E., Industrial Relations and the Social Order. Kansas City: Macmillan Company, 1946.

Moore, William E., Masonic Temples, Freemasonry, Ritual Architecture, and Masculine Archtypes. Knoxville, TN: University of Tennessee Press, 2006.

"National Park Service, Keweenaw NHP"; 50"h Anniversary Masons, Newton.

National Register of Historic Places, Laurium Historic District, Laurium, Houghton County, Michigan.

Putman, Robert, Bowling Alone: The Collapse and Revival of the American Community. New York: New York, 2001.

Rugg, Henry W., ed., The Freemason's repository. Providence,RI: E.L. Freeman \& Co, 1882-83.

Sawyer, Alvah Littlefield, A History of the Northern Peninsula of Michigan and its People. Chicago: The Lewis Publishing Co., 1911. 
Sears, Roebuck, and Co. Catalog. Chicago: Sears, Roebuck and Company, 1902.

Scott, Elizabeth M., Those of Little Note. Tucson, AZ: University of Arizona Press, 1994.

Stevens, Albert Clark, Cyclopedia of Fraternities. Forence, KY: Gale Group, 1980.

Sutherland, Robert L. and Woodward, Maxwell, Introductory Sociology. Philadelphia: Lippincott, 1948.

Tabbert, Mark A., American Freemasons. New York: NYU Press, 2006.

Transactions of the Grand Lodge of the State of Michigan. Detroit: Free Press Book and Job Printing House, 1899.

Thompson, E.P., The making of the English working class. New York: Vintage Books, 1966.

Thurner, Arthur, Calumet Copper and People: History of a Michigan Mining Community, 1864-1970. Hancock, MI: Book Concern, 1974.

Thurner, Arthur, Strangers and Sojourners. Detroit: Wayne State UP, 1994.

Turner, Viktor, From Ritual to Theatre: The Human Seriousness of Play. New York: Performing Arts Publications, 1982.

Union Building Historic Structure Report (Draft). Calumet,MI: Keweenaw National Historical Park, 2002.

Wilentz, Sean, "Rise of the Working Class," Thesis, Northern Illinois University, 1990.

Wilkie, Laurie A., The Lost Boys of Zeta Psi. Los Angeles: University of California Press, 2010.

Wright, Dudley, The Ethics of Freemasonry. 1924. Reprint, Whitefish,MT: Kessinger Publishing, 2010.

\section{Articles}

Clawson, Mary Ann, "Fraternal Orders and Class Formation in the Nineteenth-Century United States," Comparative Studies in Society and History, 27, no. 4 (1985). 
De Los Reyes, Guillermo G., and Antonio, Lara. "Civil Society and Volunteerism: Lodges in Mining Communities." Annals of the American Academy of Political and Social Science, 565 (1999)

Hermanowicz, Morgan and Morgan, Harriet P., "Ritualizing the Routine: Collective Identity Affirmation," Sociological Forum, 14, no. 2 (1999).

Jackman, Mary, "The Subjective Meaning of Social Class Identification in the United States," The Public Opinion Quarterly, 43, no. 4 (Winter 1979).

Jolicoeur, Pamela and Knowles Louis L., "Fraternal Associations and Civil Religion," Review of Religious Research, 20 (Fall 1978).

Lockwood, David, "Civic Integration and Class Formation", The British Journal of Sociology, 47, no. 3 (1996).

“The Lodge Room,” Masonic Standard 1, no. 16 (July 30, 1898).

Porteous, J. Douglas, "Social Class in Atacama Company Towns," Annals of the Association of American Geographers, 64, no. 3 (1973).

Wright, Erik Olin, “Class and Occupation," Theory and Society, 9:1 (January 1980).

\section{Archival}

“Annual Returns Calumet Lodge 271,” 1900, Acc. \# 035. Box 46, Folder 21. MTU \& CCHC.

“Annual Returns Calumet Lodge 271,” 1920, Acc. \# 035. Box 46, Folder 25. MTU \& CCHC.

“Application to Join Lodge 271." 1871. Copper Country Masons. Acc. \# 0035. Box 48, Michigan Tech Archives and Copper Country Historical Collections.

“By-laws of Calumet Lodge 271,” 1870, Acc. \# 035. Box 42, Folder 1. MTA\&CCHC.

“By-laws of Calumet Lodge 271,” 1906, Acc. \# 035. Box 42, Folder 2. MTA\&CCHC.

“By-laws of Calumet Lodge 271,” 1923, Acc. \# 035. Box 42, Folder 4. MTA\&CCHC.

By-laws and list of members of Montrose Commandery no. 38 Knights Templar : organized by dispensation from the Grand Commandery of Michigan, June 11, A.D. 1885, A.O. 767; chartered May 11, 1886, A.O. 768; adopted 1903.

Calumet, MI: Montrose Commandery, 1903. 
Calumet News, August 4, 1908, MTU \& CCHC.

Petition to Join Lodge 271, Copper Country Masons, Acc. \# 0035. Box 48, Folder 3. MTU \& CCHC.

"Montrose Commandery." Calumet Evening News, undated article. Copper Country Vertical Files, MTU \& CCHC.

“Roster of Calumet Lodge 271,” 1900, Acc. \# 035. Box 46. MTU \& CCHC.

“Roster of Calumet Lodge 271,” 1920, Acc. \# 035. Box 46. MTU \& CCHC.

"Union Building Association of Calumet records," Acc. \# 035. Box 54, Folder 4. MTU \& CCHC, 1888.

U.S. Census of Population and Housing, 1900: Summary Population and Housing Characteristics: Michigan.

\section{Websites}

“Average Nearest Neighbor," ESRI, http://edndoc.esri.com/arcobjects/9.2/net/shared/geoprocessing/spatial_statistics tools/average_nearest_neighbor_spatial_statistics_htm

"High-Low Clustering," ESRI, http://edndoc.esri.com/arcobjects/9.2/net/shared/geoprocessing/spatial_statistics _tools/high_low_clustering_getis_ord_general_g_spatial_statistics_htm. 
Appendix A: Masons from 1900 and 1920

Table A.1: List of Lodge Members in 1900

\begin{tabular}{|c|c|c|}
\hline Anderson, William J. & Middle & Yardmaster \\
\hline Andrew, Alexander & Middle & $\begin{array}{l}\text { Machinist - Tamarack } \\
\text { Mining Co. }\end{array}$ \\
\hline \multicolumn{3}{|l|}{ Beaton, Norman } \\
\hline Bennetts, J. Frank & Middle & $\begin{array}{l}\text { Instructor - Manual } \\
\text { Training School }\end{array}$ \\
\hline Blumenthal, Izzie & Working & $\begin{array}{l}\text { Seller of Clothing, Hats, } \\
\text { Caps, Men's Furnishing, } \\
\text { Boots and Shoes }\end{array}$ \\
\hline Bray, Nicholas S. & Upper Middle & Owner - Planning Mill \\
\hline Berryman, John & Working & Miner \\
\hline Brown, Elbridge & Working & Supply Clerk-C\&H \\
\hline Burder, John & Upper Middle & $\begin{array}{l}\text { Vice-President - Carlton } \\
\text { Hardware Co. }\end{array}$ \\
\hline \multicolumn{3}{|l|}{ Butler, James } \\
\hline Butler, Jesse & Working & Contractor \\
\hline Campbell, Duncan & Upper Middle & Architect \\
\hline Carlton, Frank S. & Upper Middle & $\begin{array}{l}\text { President and Treasurer - } \\
\text { Carlton Hardware Co. }\end{array}$ \\
\hline Carpenter, William E. & Middle & Machinist $-\mathrm{C} \& \mathrm{H}$ \\
\hline Clark, Angus B. & Upper Middle & Engineer \\
\hline Clark, John B. & Working & Lumber \\
\hline Collins, Edwin & Working & $\begin{array}{l}\text { Operator - Paine, Webber } \\
\text { \& Co. }\end{array}$ \\
\hline Cooley, Frank W. & Upper Middle & Superintedent of Schools \\
\hline Cornish, William & Upper Middle & Blacksmith \\
\hline Cowley, Fred L. & Working & Clerk-C\&H \\
\hline Cox, Col. James N. & Working & Clerk-C\&H \\
\hline \multicolumn{3}{|l|}{ Cunningham, Lincoln } \\
\hline Daniell, William & Middle & $\begin{array}{l}\text { Mining Captain - } \\
\text { Tamarack Mining Co. }\end{array}$ \\
\hline Daniell, William Jr. & Middle & Miner / Machinist $-\mathrm{C} \& \mathrm{H}$ \\
\hline Daniell, William E. & Middle & Mine Captain \\
\hline Danielson, John A. & Middle & Overseer $-\mathrm{C} \& \mathrm{H}$ \\
\hline Dick, Neil & Working & $\begin{array}{l}\text { Clerk - Tamarack Co- } \\
\text { operative Assn. }\end{array}$ \\
\hline Downing, John W. & Working & $\begin{array}{l}\text { Bookkeeper - Charles } \\
\text { Briggs }\end{array}$ \\
\hline Duncan, John & Upper Middle & Asst. Superintendent C\&H \\
\hline Dymock, John S. & Upper Middle & President - Bank \\
\hline
\end{tabular}




\begin{tabular}{|c|c|c|}
\hline $\begin{array}{c}\text { Table A.1, continued } \\
\text { Name }\end{array}$ & Class & Occupation \\
\hline \multicolumn{3}{|l|}{ Earn, Charles A. } \\
\hline Eaton, Fred S. & Working & Bookkeeper-C\&H \\
\hline Edwards, Richard & Working & Miner $-\mathrm{C} \& \mathrm{H}$ \\
\hline Edwards, Richard W. & Upper Middle & Engineer $-\mathrm{C} \& \mathrm{H}$ \\
\hline Engstrom, Albert J. & Working & Carrier - Post Office \\
\hline \multicolumn{3}{|l|}{ Evans, David } \\
\hline Faley, Peter L. & Working & Clerk - J P Petermann \\
\hline Fisher, George & Working & Break repairman \\
\hline \multicolumn{3}{|l|}{ Fliege, Julius E. } \\
\hline Galbraith, William J. & Upper Middle & Lawyer \\
\hline Geiger, Charles & Middle & Mason $-\mathrm{C \& H}$ \\
\hline George, Edwin & Upper Middle & Engineer \\
\hline \multicolumn{3}{|l|}{ Glocker, William H. } \\
\hline Gribble, James & Middle & $\begin{array}{l}\text { Mining Captain - } \\
\text { Tamarack Mining Co. }\end{array}$ \\
\hline Gribble, Thomas & Working & Shoemaker \\
\hline Grierson, Paul W. & Middle & $\begin{array}{l}\text { Manager - Paine, Webber } \\
\& \text { Co. }\end{array}$ \\
\hline Haas, Herman & Upper Middle & Ed. Haas \& Co. \\
\hline Hanson, Avery T. & Upper Middle & $\begin{array}{l}\text { Lawyer and Circuit Court } \\
\text { Commissioner }\end{array}$ \\
\hline Hargrave, Fred J. & Upper Middle & $\begin{array}{l}\text { President - F. J. Hargrave } \\
\text { Co. }\end{array}$ \\
\hline Harper, Martin & Working & Timekeeper \\
\hline Harris, William & Middle & $\begin{array}{l}\text { Wagonmaker - Jacob } \\
\text { Kaiser }\end{array}$ \\
\hline \multicolumn{3}{|l|}{ Hebert, Joseph } \\
\hline \multicolumn{3}{|l|}{ Hegarolt, Iwar } \\
\hline Holman, William J. & Middle & $\begin{array}{l}\text { General Insurance Agent - } \\
\text { Holman Block }\end{array}$ \\
\hline Holt, William A. & Upper Middle & Physician \\
\hline Hosking, Harry T. & Middle & $\begin{array}{l}\text { Manager - Michigan } \\
\text { Telephone Co. }\end{array}$ \\
\hline Hosking, Joshua D. & Upper Middle & Superintendent \\
\hline Hosking, William H. & Middle & Postmaster - Calumet \\
\hline Jacka, George & Working & Contractor \\
\hline Jess, Samuel & Working & Trammer $-\mathrm{C} \& \mathrm{H}$ \\
\hline Johnson, Edward D. & Upper & Supply Agent - C\&H \\
\hline Jones, Richard & Upper Middle & Dentist \\
\hline \multicolumn{3}{|l|}{ Jordan, August F. } \\
\hline Kerr, Alexander & Working & Watchman $-\mathrm{C} \& \mathrm{H}$ \\
\hline Kerr, Angus F. & Upper Middle & Lawyer - 5-6 Quello Block \\
\hline Killmar, Lucius W. & Working & Clerk-C\&H \\
\hline Kilty, John D. & Working & Clerk \\
\hline King, Harry R. & Working & Clerk-C\&H \\
\hline Kinsman, William C. & Middle & Harnessmaker \\
\hline
\end{tabular}




\begin{tabular}{|c|c|c|}
\hline $\begin{array}{c}\text { Table A.1, continued } \\
\text { Name }\end{array}$ & Class & Occupation \\
\hline \multicolumn{3}{|l|}{ Klepetko, Frank } \\
\hline Koivupalo, Edward H. & Upper Middle & Physician \\
\hline Landers, Francis R. & Middle & $\begin{array}{l}\text { Mine Captain - Osceola } \\
\text { Consolidated Mining Co }\end{array}$ \\
\hline \multicolumn{3}{|l|}{ Lathrop, Frank } \\
\hline Lawbaugh, Albert I. & Upper Middle & Physician \\
\hline \multicolumn{3}{|l|}{ Lean, Horatio S. } \\
\hline \multicolumn{3}{|l|}{ Leigh, Leonard } \\
\hline Lempea, Nels August & Working & Clerk - B. Neimark \\
\hline Light, Joseph C. & Working & Travel Agent \\
\hline Light, William J. & Middle & $\begin{array}{l}\text { Manager - Tamarack Co- } \\
\text { operative Assn. }\end{array}$ \\
\hline Little, James & Working & $\mathrm{Lab}-\mathrm{C} \& \mathrm{H}$ \\
\hline Lowe, William & Working & Launder $-\mathrm{C} \& \mathrm{H}$ \\
\hline Lyon, Frank B. & Middle & Hardware Supplies \\
\hline MacKenzie, Frederick & Upper Middle & $\begin{array}{l}\text { Proprietor - Copper } \\
\text { Country Evening News }\end{array}$ \\
\hline MacKenzie, James & Middle & Machinist \\
\hline MacKay, James F. & Working & Brakeman - C\&H \\
\hline Matheson, Thomas & Middle & Boilermaker $-\mathrm{C} \& \mathrm{H}$ \\
\hline McAuley, Alexander & Working & Fireman $-\mathrm{C} \& \mathrm{H}$ \\
\hline McDonald, Duncan & Middle & Overseer Carpenter $-\mathrm{C} \& \mathrm{H}$ \\
\hline McDonald, Norman & Upper Middle & Druggist \\
\hline \multicolumn{3}{|l|}{ McGlinnis, William B. } \\
\hline McKinnon, Dugald & Upper Middle & Timber boss $-\mathrm{C} \& \mathrm{H}$ \\
\hline McLeod, Angus & Upper Middle & Engineer $-\mathrm{C} \& \mathrm{H}$ \\
\hline McLeod, Daniel & Upper Middle & Engineer $-\mathrm{C} \& \mathrm{H}$ \\
\hline McNab, Lachlan & Working & Watchman - C\&H \\
\hline McNaughton, James & Upper & Superintendent $-\mathrm{C} \& \mathrm{H}$ \\
\hline Merton, John & Middle & Machinist $-\mathrm{C} \& \mathrm{H}$ \\
\hline Merton, James M. & Working & Draftsman $-\mathrm{C} \& \mathrm{H}$ \\
\hline Milligan, James W. & Middle & Mine Captain - C\&H \\
\hline Montin, Uno M. & Working & $\begin{array}{l}\text { Clerk - Norman } \\
\text { MacDonald }\end{array}$ \\
\hline Moore, William & Upper Middle & Engineer $-\mathrm{C} \& \mathrm{H}$ \\
\hline Morrison, John S. & Working & Miner $-\mathrm{C} \& \mathrm{H}$ \\
\hline Morrison, Macintosh M. & Middle & Foreman $-\mathrm{C} \& \mathrm{H}$ \\
\hline Nankervis, James L. & Working & $\begin{array}{l}\text { Bookkeeper - Baer } \\
\text { Brothers }\end{array}$ \\
\hline Niles, Charles W. & Upper Middle & Physician - C\&H Hospital \\
\hline Noetzel, Charles L. & Upper Middle & $\begin{array}{l}\text { Chief Clerk - Wolverine } \\
\text { Copper Mining Co }\end{array}$ \\
\hline North, Judson P. & Upper Middle & Proprietor - Calumet Hotel \\
\hline Olson, Sivert & Middle & $\begin{array}{l}\text { Furniture, Undertaker. And } \\
\text { General Household Goods }\end{array}$ \\
\hline Opie, John C. & Middle & Mine Captain - C\&H \\
\hline
\end{tabular}




\begin{tabular}{|c|c|c|}
\hline $\begin{array}{c}\text { Table A.1, continued } \\
\text { Name }\end{array}$ & Class & Occupation \\
\hline $\begin{array}{l}\text { Osborn, Reuben H. } \\
\text { Parsons, Henry }\end{array}$ & Middle & Timber Foreman $-\mathrm{C} \& \mathrm{H}$ \\
\hline Pascoe, John & Middle & $\begin{array}{l}\text { Foreman Blacksmith - } \\
\text { Tamarack Mining Co. } \\
\text { Osceola Twp. Treasurer }\end{array}$ \\
\hline Paull, Stephen & Working & $\begin{array}{l}\text { Cashier - Merchants and } \\
\text { Miners Bank }\end{array}$ \\
\hline Pearson, John M. & Middle & Music Teacher \\
\hline Peppler, Fred W. & Working & Draftsman \\
\hline Phillips, William & Middle & Master mechanic $-\mathrm{C} \& \mathrm{H}$ \\
\hline Pomeroy, Emmet H. & Upper Middle & $\begin{array}{l}\text { Physician in charge }-\mathrm{C} \& \mathrm{H} \\
\text { Hospital }\end{array}$ \\
\hline Pope, Samuel C. & Upper Middle & $\begin{array}{l}\text { Engineer - Tamarack } \\
\text { Mining Co. }\end{array}$ \\
\hline Quick, John B. & Middle & Manager-B Quello \\
\hline Rabey, James & Upper Middle & Engineer $-\mathrm{C} \& \mathrm{H}$ \\
\hline Ramsay, James D. & Upper Middle & $\begin{array}{l}\text { Superintendent Motive } \\
\text { Power - H\&TLRR }\end{array}$ \\
\hline Read, Russel H. & Upper & Pharmacist - C\&H Hospital \\
\hline Reuther, Fred C. & Working & Machinist \\
\hline Reuther, Jacob & Middle & Foreman $-\mathrm{C} \& \mathrm{H}$ \\
\hline Ritchie, James & Working & Timberman \\
\hline Ritchie, James W. & Middle & Plumber \\
\hline Ritchie, Thomas R. D. & Middle & Electrician \\
\hline Roberts, David & Working & $\mathrm{Lab}$ \\
\hline Rodi, Charles H, & Upper Middle & $\begin{array}{l}\text { Resident Physician - } \\
\text { Tamarack Hospital }\end{array}$ \\
\hline Roehm, Frederick & Middle & Plasterer-C\&H \\
\hline Roehm, Paul P. & Working & $\begin{array}{l}\text { Contractor - Coal and } \\
\text { Wood }\end{array}$ \\
\hline Rowe, John T. & Middle & $\begin{array}{l}\text { Timber foreman - } \\
\text { Tamarack Mining Co. }\end{array}$ \\
\hline Rupprecht, Charles & Middle & $\begin{array}{l}\text { Overseer Blacksmith - } \\
\text { C\&H }\end{array}$ \\
\hline Sailer, Mathew & Middle & Postmaster \\
\hline Schuller, Nicholas & Upper Middle & Engineer \\
\hline \multicolumn{3}{|l|}{ Schutte, Frederick } \\
\hline \multicolumn{3}{|l|}{ Scott, A. B. } \\
\hline Sincock, William & Middle & Blacksmith \\
\hline Soddy, Thomas H. & Middle & Foreman $-\mathrm{C} \& \mathrm{H}$ \\
\hline \multicolumn{3}{|l|}{ Sowden, James } \\
\hline Streeter, Albert T. & Upper Middle & Lawyer \\
\hline
\end{tabular}




\begin{tabular}{|c|c|c|}
\hline $\begin{array}{c}\text { Table A.1, continued } \\
\text { Name }\end{array}$ & Class & Occupation \\
\hline Sutherland, Angus & Upper Middle & Engineer \\
\hline Thielman, William & Upper Middle & $\begin{array}{l}\text { Owner - Armstrong- } \\
\text { Thielman Lumber Co. }\end{array}$ \\
\hline \multicolumn{3}{|l|}{ Tyler, Charles } \\
\hline Unsworth, George & Upper Middle & Engineer $-\mathrm{C} \& \mathrm{H}$ \\
\hline \multicolumn{3}{|l|}{ Veale, Vivian } \\
\hline Vivian, Johnson L. & Upper Middle & Owner - J Vivian Jr \& Co. \\
\hline Vivian, Johnson Jr. & Upper & $\begin{array}{l}\text { President - State Savings } \\
\text { Bank }\end{array}$ \\
\hline Ward, Francis & Upper Middle & Town Marshal \\
\hline \multicolumn{3}{|l|}{ Wareham, Charles M. } \\
\hline Wareham, Richard B. & Middle & Overseer - C\&H \\
\hline Watson, William J. & Working & Fireman \\
\hline West, William K. & Upper Middle & Physician - C\&H Hospital \\
\hline Wetzel, Robert B. & Upper & $\begin{array}{l}\text { Chief Pharmacist }-\mathrm{C} \& \mathrm{H} \\
\text { Hospital }\end{array}$ \\
\hline White, Julius & Working & Clerk \\
\hline Williams, James A. & Middle & Barber \\
\hline Williams, James W. & Upper Middle & Engineer \\
\hline Wills, Thomas & Middle & Mining Captain $-\mathrm{C} \& \mathrm{H}$ \\
\hline Wilson, James & Working & $\begin{array}{l}\text { Bookkeeper - Charles } \\
\text { Mugford }\end{array}$ \\
\hline Ziegeler, Edward G. & Middle & $\begin{array}{l}\text { Manager (Grocery Dept.) - } \\
\text { Tamarack Co-operative } \\
\text { Assn. }\end{array}$ \\
\hline
\end{tabular}


Table A.2: List of Lodge Members in 1920

\begin{tabular}{|c|c|c|}
\hline Name & Class & Occupation \\
\hline \multicolumn{3}{|l|}{ Abrams, James C. } \\
\hline Allen, James M. & Working & Rodman - C\&H \\
\hline Allen, Thomas W. & Working & Clerk - C\&H \\
\hline Anderson, William J. & Working & $\begin{array}{l}\text { Miner - Centennial Copper } \\
\text { Mining Co }\end{array}$ \\
\hline Andrew, Alexander G. & Middle & $\begin{array}{l}\text { Machinist - Centennial } \\
\text { Copper Mining Co }\end{array}$ \\
\hline Ashton, James T. & Middle & $\begin{array}{l}\text { Treasurer - Tamarack Co- } \\
\text { operative Assn }\end{array}$ \\
\hline Baldwin, Alfred & Upper Middle & Dentist \\
\hline Barkell, John B. & Upper Middle & $\begin{array}{l}\text { Engineer - Mineral Range } \\
\text { RR }\end{array}$ \\
\hline Barnham, Burton & Working & Dyeing and cleaning \\
\hline Bast, Edward P. & Middle & $\begin{array}{l}\text { Assistant Manager - State } \\
\text { Savings Bank }\end{array}$ \\
\hline Bennetts, J. Francis & Working & $\begin{array}{l}\text { Asst. Cashier - State Savings } \\
\text { Bank }\end{array}$ \\
\hline Bennetts, John J. & Middle & Shift Boss - C\&H \\
\hline Bennetts, Samuel & Upper Middle & $\begin{array}{l}\text { General Manager - } \\
\text { Tamarack Co-operative } \\
\text { Assn }\end{array}$ \\
\hline Berriman, William & Working & Miner - $\mathrm{C} \& \mathrm{H}$ \\
\hline Berryman, John & Middle & Blacksmith \\
\hline Berryman, Thomas H. & Working & Brass smelter \\
\hline Biscombe, Joseph R. & Middle & Mine Captain (OCM Co.) \\
\hline Bloy, Wilbur A. & Upper Middle & Owner, Bloy Furniture \\
\hline \multicolumn{3}{|l|}{ Boase, John C. } \\
\hline \multicolumn{3}{|l|}{ Broan, J. M. } \\
\hline Bruns, Oscar W. & Upper Middle & $\begin{array}{l}\text { Secretary - Santa Rosalia } \\
\text { Gold Mining Co. }\end{array}$ \\
\hline \multicolumn{3}{|l|}{ Butler, James } \\
\hline \multicolumn{3}{|l|}{ Burder, John } \\
\hline Cameron, Allan & Upper & $\begin{array}{l}\text { Chief Mining Captain - } \\
\text { C\&H }\end{array}$ \\
\hline Campbell, Gordon R. & Upper & $\begin{array}{l}\text { President - People's Fuel } \\
\text { Company }\end{array}$ \\
\hline Carlton, Frank S. & Upper & $\begin{array}{l}\text { President - Carlton } \\
\text { Hardware Co. }\end{array}$ \\
\hline Chynoweth, James H. & Upper Middle & $\begin{array}{l}\text { Shift Boss - Centennial } \\
\text { Mining Co. }\end{array}$ \\
\hline Chynoweth, [Silas] C. & Middle & Manager - Insurance Agency \\
\hline
\end{tabular}




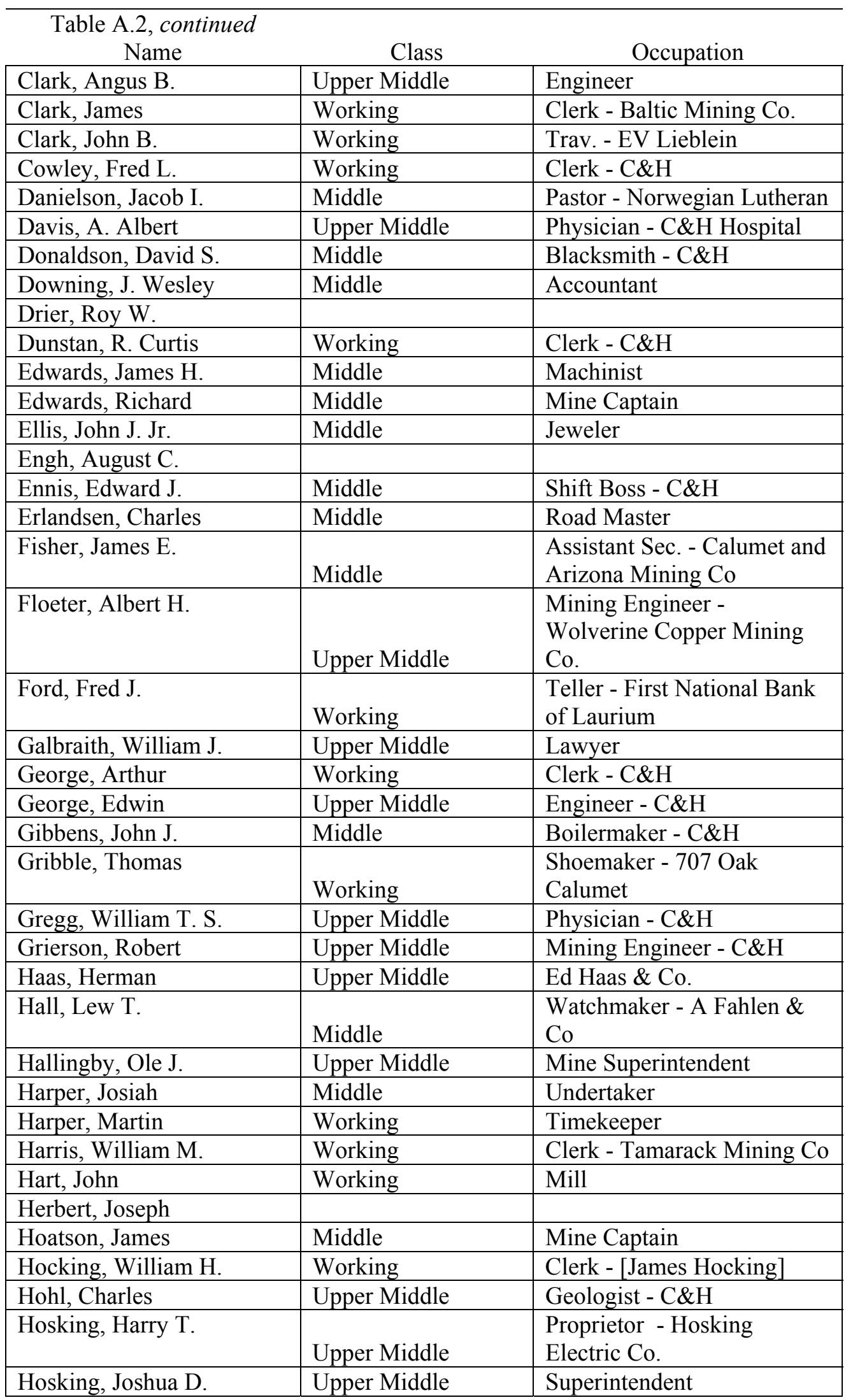




\begin{tabular}{|c|c|c|}
\hline $\begin{array}{c}\text { Table A.2, continued } \\
\text { Name }\end{array}$ & Class & Occupation \\
\hline Hosking, Samuel B. & Upper Middle & Clerk - Tamarack Mining Co \\
\hline Ingersoll, Harry T. & Middle & $\begin{array}{l}\text { President Pro Tem - } \\
\text { Laurium village }\end{array}$ \\
\hline Jacka, George & Working & Lumber \\
\hline James, William D. & Working & $\begin{array}{l}\text { Bookkeeper - ER Godfrey \& } \\
\text { Sons Co }\end{array}$ \\
\hline Jess, Samuel & Middle & Mine Captain - C\&H \\
\hline Johns, Henry & Working & Timekeeper - C\&H \\
\hline Jones, Arthur C & Upper Middle & Agent, Mineral Range RR \\
\hline Jones, Richard D. & Upper Middle & Dentist \\
\hline Keckonen, Oscar & Upper Middle & $\begin{array}{l}\text { Owner - Keckonen } \\
\text { Hardware Co }\end{array}$ \\
\hline Kerr, Alexander & Working & Watchman \\
\hline Kerr, John D. & Upper Middle & $\begin{array}{l}\text { Lawyers - MacDonald \& } \\
\text { Kerr }\end{array}$ \\
\hline King, Harry E. & Middle & $\begin{array}{l}\text { Manager - Calumet } \\
\text { Coliseum }\end{array}$ \\
\hline King, Harry R. & Working & Clerk - C\&H \\
\hline King, James Arthur & Working & Mine Clerk \\
\hline King, William T. & Upper Middle & Physician \\
\hline Kinsman, William C. & Middle & Proprietor - Harness Shop \\
\hline Kohlhaas, Frank J. & Upper Middle & $\begin{array}{l}\text { Vice President \& Cashier - } \\
\text { Calumet State Bank }\end{array}$ \\
\hline Kohlhass, Joseph G. & Middle & $\begin{array}{l}\text { Manager - Calumet Branch - } \\
\text { Pabst Brewing Co, Chief of } \\
\text { Police }\end{array}$ \\
\hline Koivupalo, Edward & Upper Middle & Physician \\
\hline Lempea, Nels A. & Upper Middle & Agent \\
\hline Lantz, Frederick H. & Middle & Meats \\
\hline Lawbaugh, A. I. & Upper Middle & Physician \\
\hline \multicolumn{3}{|l|}{ Lean, Horatio S. } \\
\hline \multicolumn{3}{|l|}{ Lean, Merton S. [Mertin] } \\
\hline Lewis, John & Upper Middle & Foreman - C\&H \\
\hline Lobb, Leslie H. & Middle & Rollerman - C\&H \\
\hline MacDonald, Robert B. & & Student \\
\hline Mackay, James E. & Working & Inspector \\
\hline Mackenzie, Clyde S. & Middle & Register of Deeds \\
\hline Mackenzie, Robert B. & Middle & Manager - Sivert Olsen Co \\
\hline Mackenzie, William S. & Middle & Carpenter - C\&H \\
\hline MacNaughton, James & Upper & General Manager - C\&H \\
\hline McAuley, Archibald & Middle & Machinist \\
\hline McAuley, Alex & Upper Middle & Engineer - C\&H \\
\hline McClelland, Leslie C. & Upper Middle & McClelland \& Roberts \\
\hline McClelland, Peter J. & Working & Supply Clerk - C\&H \\
\hline \multicolumn{3}{|l|}{$\mathrm{M}[\mathrm{a}] \mathrm{cDonald}$, Norman } \\
\hline McHardy, James & Middle & Red Jacket Carriage Works \\
\hline
\end{tabular}




\begin{tabular}{|c|c|c|}
\hline $\begin{array}{c}\text { Table A.2, continued } \\
\text { Name }\end{array}$ & Class & Occupation \\
\hline McKelvie, John & Working & Clerk \\
\hline McKelvie, William & Upper Middle & $\begin{array}{l}\text { Secretary-Treasurer - M Van } \\
\text { Orden Co. }\end{array}$ \\
\hline M[a]cKenzie, William & Upper Middle & Engineer - C\&H \\
\hline McKenzie, James & Working & Inspector \\
\hline M[a]cKenzie, James A. & Middle & Blacksmith \\
\hline M[a]cKenzie, William A. & Middle & Trammer Boss - C\&H \\
\hline McKinnon, Angus & Working & $\mathrm{Lab}-\mathrm{C} \& \mathrm{H}$ \\
\hline McKinnon, William R. & Upper Middle & Physician \\
\hline McKinnon, John D. & Upper Middle & Physician - C\&H \\
\hline McLean, George W. & Working & Draftsman - C\&H \\
\hline McLeod, Kenneth & Working & $\mathrm{Lab}-\mathrm{C} \& \mathrm{H}$ \\
\hline McLeod, Malcolm & Working & Transfering, trucking \\
\hline McLelland, Charles & Middle & Mine Captain - C\&H \\
\hline McMillan, Thomas W. & Working & Conductor - HCTCo \\
\hline McNab, Joseph & Working & Helper - C\&H Hospital \\
\hline McPhail, John A. & Middle & $\begin{array}{l}\text { Proprietor - The Bee Hive } \\
\text { Store }\end{array}$ \\
\hline Malfroid, Nestor E. & Upper Middle & $\begin{array}{l}\text { Manager - Malfroid Trading } \\
\text { Co. }\end{array}$ \\
\hline Matheson, Thomas & Middle & Boilermaker - C\&H \\
\hline Medland, Clarence E. & Working & Oiler - C\&H \\
\hline Milford, William F. & Middle & Contractor \\
\hline \multicolumn{3}{|l|}{ Milligan, James W. } \\
\hline Minnear, Joseph A. & Upper Middle & Owner - JA Minnear \& Co. \\
\hline \multicolumn{3}{|l|}{ Morrison, M. M. } \\
\hline Murray, Frank & Working & Trammer Boss - C\&H \\
\hline \multicolumn{3}{|l|}{ Nadeu, Frank } \\
\hline \multicolumn{3}{|l|}{ Nelson, Nels A. } \\
\hline Nicholas, Alonzo D. & Upper & Chief Clerk - C\&H \\
\hline Nicholas, Francis J. & Upper & $\begin{array}{l}\text { Chief Clerk - Copper Range } \\
\text { RR }\end{array}$ \\
\hline \multicolumn{3}{|l|}{ Nilsson, Martin M. } \\
\hline Noetzel, Charles & Upper Middle & $\begin{array}{l}\text { Purchasing Agent - } \\
\text { Wolverine Copper Mining } \\
\text { Co }\end{array}$ \\
\hline North, Judson P. & Upper Middle & Proprietor - Calumet Hotel \\
\hline Odgers, Richard E. & Working & $\begin{array}{l}\text { Cashier - First National } \\
\text { Bank of Hubbell }\end{array}$ \\
\hline Old, Thomas W. & Middle & Blacksmith - C\&H \\
\hline Olsen, Harold & Working & Telephone Operator \\
\hline Opie, John C. & Middle & $\begin{array}{l}\text { Assistant Trammer Boss - } \\
\text { Isle Royale }\end{array}$ \\
\hline Orenstein, Fred G. & Working & Clerk - James Orenstein \\
\hline Orenstein, James & Middle & $\begin{array}{l}\text { Manufacturing Furrier - } \\
\text { Clothier }\end{array}$ \\
\hline
\end{tabular}




\begin{tabular}{|c|c|c|}
\hline $\begin{array}{c}\text { Table A.2, continued } \\
\text { Name }\end{array}$ & Class & Occupation \\
\hline Pascoe, John & Middle & $\begin{array}{l}\text { Blacksmith - Tamarack } \\
\text { Mining Co }\end{array}$ \\
\hline Paull, Harry T. & Working & Clerk \\
\hline \multicolumn{3}{|l|}{ Paull, John H. } \\
\hline Paull, Stephen & Working & $\begin{array}{l}\text { Cashier - Merchants and } \\
\text { Miners Bank }\end{array}$ \\
\hline Paull, Stephen C. & Working & $\begin{array}{l}\text { Assistant Clerk - Tamarack } \\
\text { Mining Co }\end{array}$ \\
\hline Peppler, Fred & Working & Draftsman - C\&H \\
\hline Perry, James S. & Upper Middle & Pharmacist - C\&H \\
\hline Petermann, Albert E. & Upper Middle & $\begin{array}{l}\text { Lawyer - First National } \\
\text { Bank of Calumet }\end{array}$ \\
\hline Phillips, Thomas A. & Working & Helper - C\&H \\
\hline Polglase, Edward H. & Upper Middle & $\begin{array}{l}\text { Engineer - Wolverine } \\
\text { Copper Mining Co }\end{array}$ \\
\hline Polglase, Herbert, J. & Middle & Music Teacher \\
\hline Pollard, William & Middle & $\begin{array}{l}\text { Machinist - Wolverine } \\
\text { Copper Mining Co }\end{array}$ \\
\hline Preuss, Gustav & Upper Middle & $\begin{array}{l}\text { Chief of Fire Department - } \\
\text { Laurium }\end{array}$ \\
\hline Read, Russell H[arry] & Upper Middle & Druggist \\
\hline Redman, Harry M. & Working & Timekeeper \\
\hline Renton, Orlando & Middle & Boilermaker - C\&H \\
\hline Roberts, Pierce & Middle & $\begin{array}{l}\text { Auditor - First National } \\
\text { Bank }\end{array}$ \\
\hline Roberts, William J. & Midde & Blacksmith - OCMCo \\
\hline Robertson, Henry & Middle & Blacksmith \\
\hline \multicolumn{3}{|l|}{ Roehm, Hiram H. } \\
\hline Roehm, Paul P. & Working & Contractor \\
\hline Roehm, Paul P. D. & Working & Laborer \\
\hline \multicolumn{3}{|l|}{ Roehm, William S. } \\
\hline Rogers, Samuel & Upper Middle & $\begin{array}{l}\text { Asssistant Mining Engineer - } \\
\text { Wolverine C M Co }\end{array}$ \\
\hline Ross, Elden & Working & $\begin{array}{l}\text { Clerk - Tamarack Co- } \\
\text { operative Assn }\end{array}$ \\
\hline Rowe, John T. & Middle & Deputy Food Inspector \\
\hline Rule, Arthur & Working & Clerk \\
\hline Rupprecht, Charles H. & Upper Middle & $\begin{array}{l}\text { Phsyician - Tamarack } \\
\text { Hospital }\end{array}$ \\
\hline Salmon, Herbert M. & Working & Clerk, C\&H Hospital \\
\hline Scott, A. B. & Working & Warehouse Laborer \\
\hline Scott, Harry S. & Middle & Printer \\
\hline \multicolumn{3}{|l|}{ Sjoland, Feliz R. } \\
\hline Sharp[e], James & Middle & Blacksmith - C\&H \\
\hline Skinner, Sydney [Sidney] & Working & Miner - C\&H \\
\hline Schmidt, Frank O. & Working & Chauffeur \\
\hline
\end{tabular}




\begin{tabular}{|c|c|c|}
\hline $\begin{array}{c}\text { Table A.2, continued } \\
\text { Name }\end{array}$ & Class & Occupation \\
\hline Smith, Willard J. & Upper Middle & $\begin{array}{l}\text { Vice-President - Smith, } \\
\text { Byers, Sparks Co. }\end{array}$ \\
\hline Smith, S. R. & Upper & Mine Supt. \\
\hline Soddy, Francis [Frank] D. & Middle & Foreman - C\&H \\
\hline Soddy, Thomas H. & Upper & Supt. Motive Power - C\&H \\
\hline Soddy, Thomas P. & & Student \\
\hline Spitz, John & Working & $\begin{array}{l}\text { Clerk - South Range } \\
\text { Mercantile Co. }\end{array}$ \\
\hline Spry, J. Henry & Working & $\begin{array}{l}\text { Clerk - Centennial Copper } \\
\text { Mining Co. }\end{array}$ \\
\hline Spurr, John & Middle & Grocer \\
\hline \multicolumn{3}{|l|}{ Steckbauer, William E. } \\
\hline Stevens, Ernest & Middle & Machinist - $\mathrm{C} \& \mathrm{H}$ \\
\hline \multicolumn{3}{|l|}{ Stevens, Samuel } \\
\hline Stitgen, M[ichael]. J. & Working & $\begin{array}{l}\text { Despatcher - Mineral Range } \\
\text { RR }\end{array}$ \\
\hline Sutherland, Angus & Upper Middle & $\begin{array}{l}\text { Engineer - Mineral Range } \\
\text { RR }\end{array}$ \\
\hline Sweeney, David B. & Working & Ticket Clerk - C\&H \\
\hline Swykert, Joseph & Middle & Grocer \\
\hline Theilman, William H. & Upper Middle & $\begin{array}{l}\text { Owner - Theilman Lumber } \\
\text { Co }\end{array}$ \\
\hline Thomas, Cleveland Earl L. & Upper Middle & Thomas Insurance Agency \\
\hline \multicolumn{3}{|l|}{ Trevarthen, Richard S. } \\
\hline Tucker, Albert R. & Upper Middle & Physician \\
\hline Ulseth, Edward & Middle & $\begin{array}{l}\text { Contractor and Builder - } \\
\text { Building Supplies }\end{array}$ \\
\hline Unsworth, George & Upper Middle & Engineer - $\mathrm{C} \& \mathrm{H}$ \\
\hline Vincent, Richard & Upper Middle & $\begin{array}{l}\text { Secretary and Manager - } \\
\text { People's Fuel Co }\end{array}$ \\
\hline Vivian, Johnson & Upper Middle & Proprietor - J. Vivian Jr. Co. \\
\hline Walsworth, A. M. & Middle & Principal - School \\
\hline \multicolumn{3}{|l|}{ Ward, Francis [Frank] } \\
\hline Warren, August & Upper Middle & $\begin{array}{l}\text { Proprietor - Warren Jewelry } \\
\text { Co }\end{array}$ \\
\hline Watson, James R. & Upper Middle & Dentist \\
\hline Weir, William Jr. & Working & Clerk - C\&H \\
\hline Wetzel, Robert M. & Upper Middle & Pharmacist - C\&H \\
\hline White, Julius & Working & Clerk - JP Petermann \\
\hline Williams, Arthur & Middle & $\begin{array}{l}\text { Mining Captain - Wolverine } \\
\text { Copper Mining Co }\end{array}$ \\
\hline Williams, George & Working & $\begin{array}{l}\text { Timekeeper - Mineral Range } \\
\text { RR }\end{array}$ \\
\hline Williams, James A. & Upper Middle & Engineer - C\&H \\
\hline Williams, James W. & Working & $\mathrm{Lab}-\mathrm{C} \& \mathrm{H}$ \\
\hline Williams, John T. & Upper Middle & Engineer \\
\hline
\end{tabular}




$\begin{gathered}\text { Table A.1, continued } \\
\text { Name }\end{gathered}$
\begin{tabular}{|l|l|l|}
\hline Williamsen, Erik [Eric] & Working & Miner - C\&H \\
\hline Wills, Joseph & Upper Middle & Village Preisdent - Laurium \\
\hline Wills, William H. & Working & $\begin{array}{l}\text { Supply Clerk - Tamarack } \\
\text { Mining Co }\end{array}$ \\
\hline Wilsterman, William H. G. & Middle & $\begin{array}{l}\text { Manager - Edison, Moore \& } \\
\text { Co. }\end{array}$ \\
\hline Wilson, Alex N. & Middle & Machinist \\
\hline Wilson, Ralph W. & Middle & Dept. Manager \\
\hline Ziegeler, Edward G. & Working & Bedding maker \\
\hline
\end{tabular}

